NBER WORKING PAPER SERIES

\title{
BANKING CRISES: AN EQUAL OPPORTUNITY MENACE
}

\author{
Carmen M. Reinhart \\ Kenneth S. Rogoff \\ Working Paper 14587 \\ http://www.nber.org/papers/w14587
}

\section{NATIONAL BUREAU OF ECONOMIC RESEARCH \\ 1050 Massachusetts Avenue \\ Cambridge, MA 02138}

December 2008

The authors are grateful to Vincent Reinhart, Keyu Jin, Tarek Hassan, Vania Stavrakeva for useful comments and suggestions on an earlier draft, and to Cesar Sosa, Chenzi Xu and Jan Zilinsky for excellent research assistance. The views expressed herein are those of the author(s) and do not necessarily reflect the views of the National Bureau of Economic Research.

NBER working papers are circulated for discussion and comment purposes. They have not been peerreviewed or been subject to the review by the NBER Board of Directors that accompanies official NBER publications.

(C) 2008 by Carmen M. Reinhart and Kenneth S. Rogoff. All rights reserved. Short sections of text, not to exceed two paragraphs, may be quoted without explicit permission provided that full credit, including $(\odot)$ notice, is given to the source. 
Banking Crises: An Equal Opportunity Menace

Carmen M. Reinhart and Kenneth S. Rogoff

NBER Working Paper No. 14587

December 2008

JEL No. E6,F3,N0

\begin{abstract}
The historical frequency of banking crises is quite similar in high- and middle-to-low-income countries, with quantitative and qualitative parallels in both the run-ups and the aftermath. We establish these regularities using a unique dataset spanning from Denmark's financial panic during the Napoleonic War to the ongoing global financial crisis sparked by subprime mortgage defaults in the United States.

Banking crises dramatically weaken fiscal positions in both groups, with government revenues invariably contracting, and fiscal expenditures often expanding sharply. Three years after a financial crisis central government debt increases, on average, by about 86 percent. Thus the fiscal burden of banking crisis extends far beyond the commonly cited cost of the bailouts. Our new dataset includes housing price data for emerging markets; these allow us to show that the real estate price cycles around banking crises are similar in duration and amplitude to those in advanced economies, with the busts averaging four to six years. Corroborating earlier work, we find that systemic banking crises are typically preceded by asset price bubbles, large capital inflows and credit booms, in rich and poor countries alike.
\end{abstract}

Carmen M. Reinhart

University of Maryland

School of Public Policy

and Department of Economics

4105 Van Munching Hall

College Park, MD 20742

and NBER

creinhar@umd.edu

Kenneth S. Rogoff

Thomas D Cabot Professor of Public Policy

Economics Department

Harvard University

Littauer Center 232

Cambridge, MA 02138-3001

and NBER

krogoff@harvard.edu 


\section{Introduction}

Until very recently, the study of banking crises has typically focused either on earlier historical experiences in advanced countries, mainly the banking panics before World War II, or else has focused on modern-day emerging market experiences. ${ }^{1}$ This dichotomy is perhaps shaped by the belief that for advanced economies, destabilizing, systemic, multi-country financial crises were a relic of the past. ${ }^{2}$ Of course, the recent global financial crisis emanating out of the United States and Europe has dashed this misconception, albeit at great social cost.

As this paper will demonstrate, banking crises have long been an equal opportunity menace. We develop this finding using a core sample of sixty-six countries (plus a broader extended sample for some exercises). ${ }^{3}$ We examine banking crises ranging from Denmark's financial panic during the Napoleonic War to the current "first global financial crisis of the $21^{\text {st }}$ century." The incidence of banking crises proves to be remarkably similar in the high- and middle-to-low-income countries. Indeed, the tally of crises is particularly high for the world's financial centers: the United Kingdom, the United States, and France. Perhaps more surprising still are the qualitative and quantitative parallels across disparate income groups. These parallels arise despite the relatively pristine modern sovereign default records of the rich countries.

Three features of our expansive dataset are of particular note. First, our data on global banking crises go back to 1800 , extending the careful study of Bordo, et al. (2001) that covers

\footnotetext{
${ }^{1}$ See Calomiris and Gorton (1991) and Gorton (1988) on pre-WWII banking panics; Sundararajan and Baliño (1991) for several emerging market case studies; Jácome (2008) on banking crises in Latin America.

${ }^{2}$ Studies that encompass episodes in both advanced and emerging economies include Bordo et al. (2001), Demirgüç-Kunt and Detragiache (1998) and Kaminsky and Reinhart (1999).

${ }^{3}$ The core sample spans 66 advanced and emerging market economies in Africa, Asia, Europe, Latin and North America and Oceania; see Appendix Table A1. The extended sample includes all countries, see Table A3.
} 
back to 1880 . Second, to our knowledge, we are the first to examine the patterns of housing prices around major banking crises in emerging markets, including Asia, Europe and Latin America. Our emerging market data set facilitates comparisons, across both duration and magnitude, with the better-documented housing price cycles in the advanced economies, which have long been known to play a central role in financial crises. ${ }^{4}$ We find that real estate price cycles around banking crises are similar in duration and amplitude across the two groups of countries. This result is surprising given that almost all other macroeconomic and financial time series (income, consumption, government spending, interest rates, etc.) exhibit higher volatility in emerging markets. ${ }^{5}$

Third, our analysis employs the comprehensive historical data on central government tax revenues and debt compiled in Reinhart and Rogoff $(2008 \mathrm{a}, \mathrm{c})$. These new data afford a new perspective on the tax and debt consequences of the banking crises (Previously, the kind of historical data on debt necessary to analyze the aftermath of banking crises across countries was virtually non-existent for years prior to $1990 .^{6}$ )

We find that banking crises almost invariably lead to sharp declines in tax revenues as well significant increases in government spending (a share of which is presumably dissipative). On average, government debt rises by 86 percent during the three years following a banking crisis. These indirect fiscal consequences are thus an order of magnitude larger than the usual bank bailout costs that are the centerpiece of most previous studies. That fact that the magnitudes are comparable in advanced and emerging market economies is also quite remarkable. Obviously, both the bailout costs and the fiscal costs depend on a host of political

\footnotetext{
${ }^{4}$ See Reinhart and Rogoff (2008b) for an analysis of all post-WWII banking crises in advanced economies.

${ }^{5}$ See, for instance, Agénor, McDermott, and Prasad (2000).

${ }^{6}$ Bordo and Meissner (2006) offer domestic debt data for selected years across 30 countries for 1880-1913, while Jeanne and Guscina (2006) provide domestic debt for 19 countries for 1980-2005. The Reinhart and Rogoff (2008c) time series for sixty-six countries spans 1913-2007, and much earlier for a large subset of these countries.
} 
and economic factors, including especially the policy response as well as the severity of the real shock which, typically, triggers the crisis. ${ }^{7}$

The paper proceeds as follows. Section II provides an overview of the history of banking crises, with particular emphasis on the post-1900 experience. We also document the incidence and frequency of banking crises by country and by region. We discuss the links between banking crises, financial liberalization, the degree of capital mobility, and sovereign debt crises and discuss international financial contagion.

Section III examines some of the common features in the run-up to banking crises across countries and regions over time. The focus is on the systematic links between cycles in international capital flows, credit, and asset prices—specifically, home and equity prices. The next section examines some of the common features of the aftermath of banking crises. We document the toll that the crisis takes on output and government revenues, as well as the typically profound effect on the evolution of government debt during the years following the crisis. The concluding section takes up the question of "graduation." Specifically, to what extent do countries ever "graduate" from (stop experiencing) serial major financial crises as they seem to graduate from serial sovereign debt crises? ${ }^{8}$

\footnotetext{
${ }^{7}$ Reinhart and Rogoff 2008a,c show that output growth typically decelerates in advance of a crisis.

${ }^{8}$ An example of graduate from serial default is France, which defaulted 8 times on its external debt between 1500 and 1800 , but has not defaulted since.
} 


\section{Banking Crises in Historical Perspective}

We begin this section by providing an overview of the evolution of banking crises through history. To do so, it is necessary to first identify and date banking crisis episodes. Our approach, which follows the standard methodology in the literature (e.g., Kaminsky and Reinhart, 1999, Bordo, et al., 2001, and Caprio and Klingebiel, 2005, among others), is documented in detail in the appendix, along with our principal bibliographical sources. ${ }^{9}$

One dimension that distinguishes this study from previous efforts is that our dating of crises extends far before the much-studied modern post-World War II era. Specifically, we start in 1800 . Our work was greatly simplified back to 1880 by the careful study of Bordo, et al. (2001), but for the earlier period we had to resort to old and often obscure works. The earliest advanced-economy banking crisis in our sample is France 1802; early crises in emerging markets befell India, 1863, China (several episodes during the 1860s-1870s), and Peru in $1873 .^{10}$

It may come as a surprise to the reader that previous attempts to document banking crises for the pre-World War II period are so limited. The problem is that because domestic banking crises do not typically impinge on large powerful creditors in the international financial centers, they do not leave the same imprint on the global press as, say, sovereign external defaults. For this reason, we acknowledge that despite our best efforts, our chronology may be missing a number of banking crises in emerging markets prior to World War II. ${ }^{11}$ Fortunately, banking crisis episodes in the developed world tend to be better documented even throughout the $19^{\text {th }}$ century.

\footnotetext{
${ }^{9}$ See also Reinhart and Rogoff (2008a).

${ }^{10}$ The work of Andrea McElderry (1976) and Cheng (2003) was invaluable in developing the timeline for China. The Peruvian case comes from a little-known 1957 book published in Lima by Carlos Camprubí Alcázar.

${ }^{11}$ The challenges encountered in dating banking crises are along similar lines as those faced when trying to construct a chronology of sovereign default on domestic debt, see Reinhart and Rogoff (2008c).
} 


\section{The Big Picture: Banking and Sovereign Debt Crises}

Figure 1 plots the incidence of banking crises among the countries in our sample (which account for about 90 percent of world GDP). Specifically, the figure shows the percentage of all independent countries during 1900-2008 having a banking crisis in any given year. The tally weighs countries by their share of global GDP. This weighted aggregate is meant to provide a measure of the "global" impact of individual banking crises. As such, a crisis in the United States or Germany is accorded a much higher weight than a crisis in Angola or Honduras, all of which are part of our 66-country sample. 
Figure 1

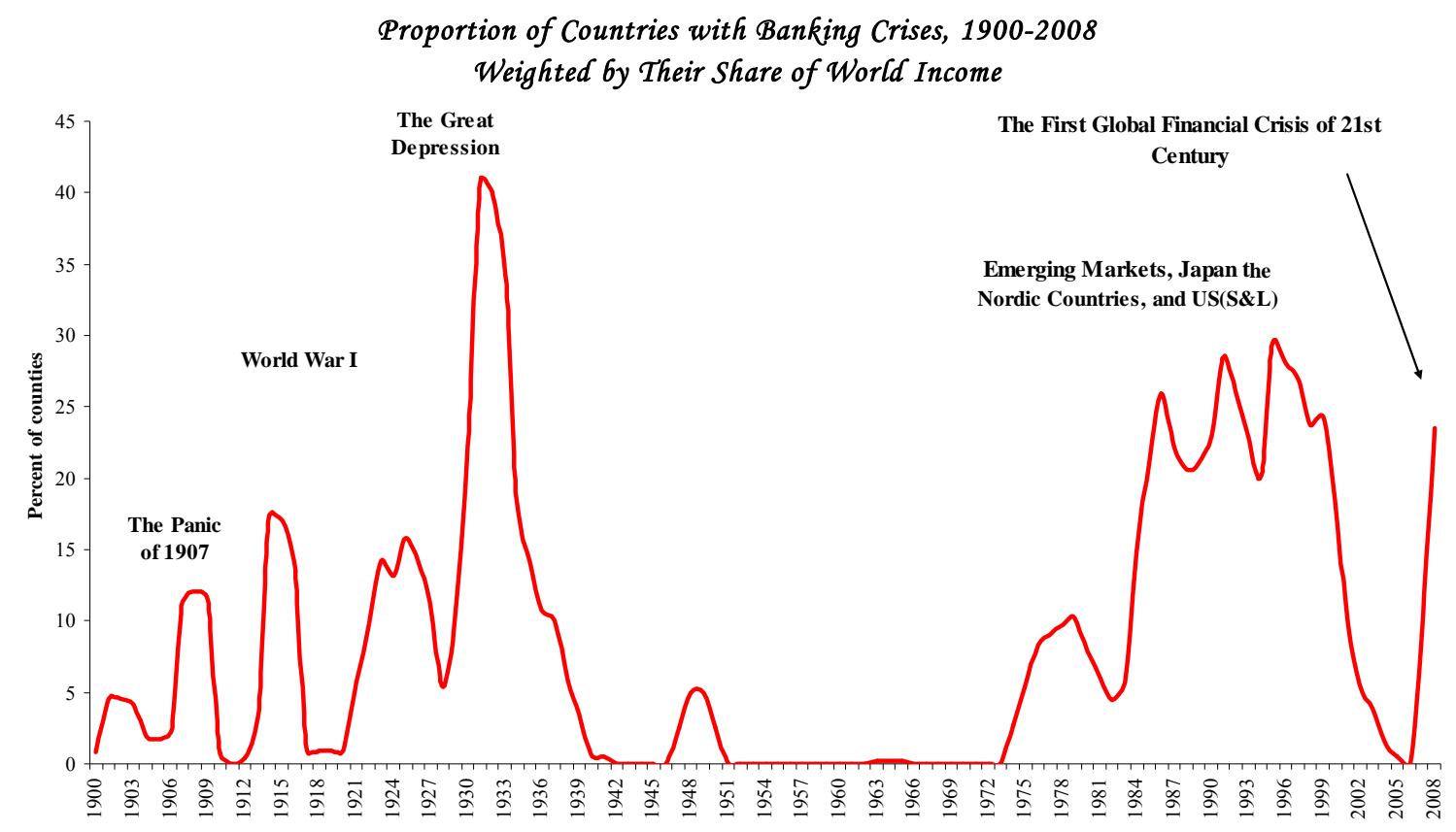

Sources: Bordo et al. (2001), Caprio et al. (2005), Kaminsky and Reinhart (1999), Jácome (2008), Maddison (2003), and additional sources listed in Appendix II, which provides banking crises dates.

Notes: Sample size includes all 66 countries listed in TableA1 that were independent states in the given year. Three sets of GDP weights are used, 1913 weights for the period 1800-1913, 1990 for the period 1914-1990, and finally 2003 weights for the period 1991-2006. The entries for 2007-2008 list crises in Austria, Belgium, Germany, Hungary, Japan, the Netherlands, Spain, the United Kingdom, and the United States. The figure shows a three-year moving average.

It is no surprise that the worldwide Great Depression of the 1930s posts the highest readings of banking crises during this 109-year stretch. Earlier, less widespread, "waves" of global financial stress are evident during and around the Panic of 1907 that originated in New York, as well as the crises accompanying the outbreak of the First World War. Another striking feature of Figure 1 is the relative calm during the late 1940s to the early 1970s. This calm may be partly explained by booming world growth, but perhaps more so by the repression of the domestic financial markets (in varying degrees) and the heavy-handed use of capital controls that followed for many years after World War II. (We are not necessarily implying that such repression and controls are the right approach to dealing with the risk of financial crises.) 


\section{Since the early 1970s, financial and international capital account liberalization took}

root worldwide. So, too, have banking crises. After a long hiatus, the share of countries having banking difficulties first began to expand in the 1970s. The break-up of the Bretton Woods system of fixed exchange rates together with the sharp spike in oil prices catalyzed a prolonged global recession, resulting in financial sector difficulties in a number of advanced economies. In the early 1980s, a collapse in global commodity prices combined with high and volatile interest rates in the United States contributed to a spate of banking and sovereign debt crises in emerging economies, most famously in Latin America and then Africa.

The United States had its savings and loan crisis beginning in 1984. During the late 1980s and early 1990s, the Nordic countries experienced some of the worst banking crises the wealthy economies had known in post-WWII following a surge in capital inflows and real estate prices. In 1992, Japan's asset price bubble burst and ushered in a decade-long banking crisis. Around the same time, with the collapse of the Soviet bloc, several formerly communist countries in Eastern Europe soon joined the ranks of nations facing banking sector problems. As the second half of the 1990s approached, emerging markets quickly faced a fresh round of banking crisis. Problems in Mexico and Argentina (1994-1995) were followed by the famous Asian crisis of 1997-1998, and then the troubles of Russia and Colombia, among others. ${ }^{12}$ Argentina in 2001 and Uruguay in 2002 closed that upswing in the banking crisis cycle.

A brief tranquil period came to an abrupt halt in the summer of 2007 when the subprime crisis in the United States began in earnest, soon morphing into a global financial crisis. ${ }^{13}$

\footnotetext{
${ }^{12}$ While China's heavy-handed capital controls shielded it from contagious currency crashes during Asia's turmoil, it did not protect it from a systemic and costly banking crisis emanating primarily from large-scale lending to inefficient and bankrupt state-owned enterprises.

${ }^{13}$ Figure 1 does not fully capture the extent of the present upsurge in financial crises, as Ireland and Iceland (both having banking crises at the time of this writing) are not part of our core 66-country sample.
} 
A high incidence of global banking crises has historically been associated with a high incidence of sovereign defaults of external debt. Figure 2 plots the (GDP-weighted) share of countries experiencing a banking crisis, as shown in Figure 1 and described above, against the comparably calculated share of countries experiencing a default or restructuring in their external debt. Sovereign defaults begin to climb with the onset of WWI (as do banking crises) and continue to escalate during the Great Depression and World War II. The decades that follow are relatively quiet, until debt crises sweep emerging markets beginning in the $1980 \mathrm{~s} .{ }^{14}$ It remains to be seen whether the recent global surge in financial sector turbulence will lead to a similar outcome in the sovereign default cycle. Figure 2 suggests that a sharp rise in sovereign defaults would hardly be surprising.

\footnotetext{
${ }^{14}$ Note that in Figure 2 the debt crises of the 1980s do not loom as large as the previous cycle of defaults, as only middle- and low-income countries faced default, while in addition to emerging market economies several advanced economies defaulted during the Great Depression and several more defaulted during WWII.
} 
Figure 2

Proportion of Countries with Banking and De6t Crises

Weighted by Their Share of World Income

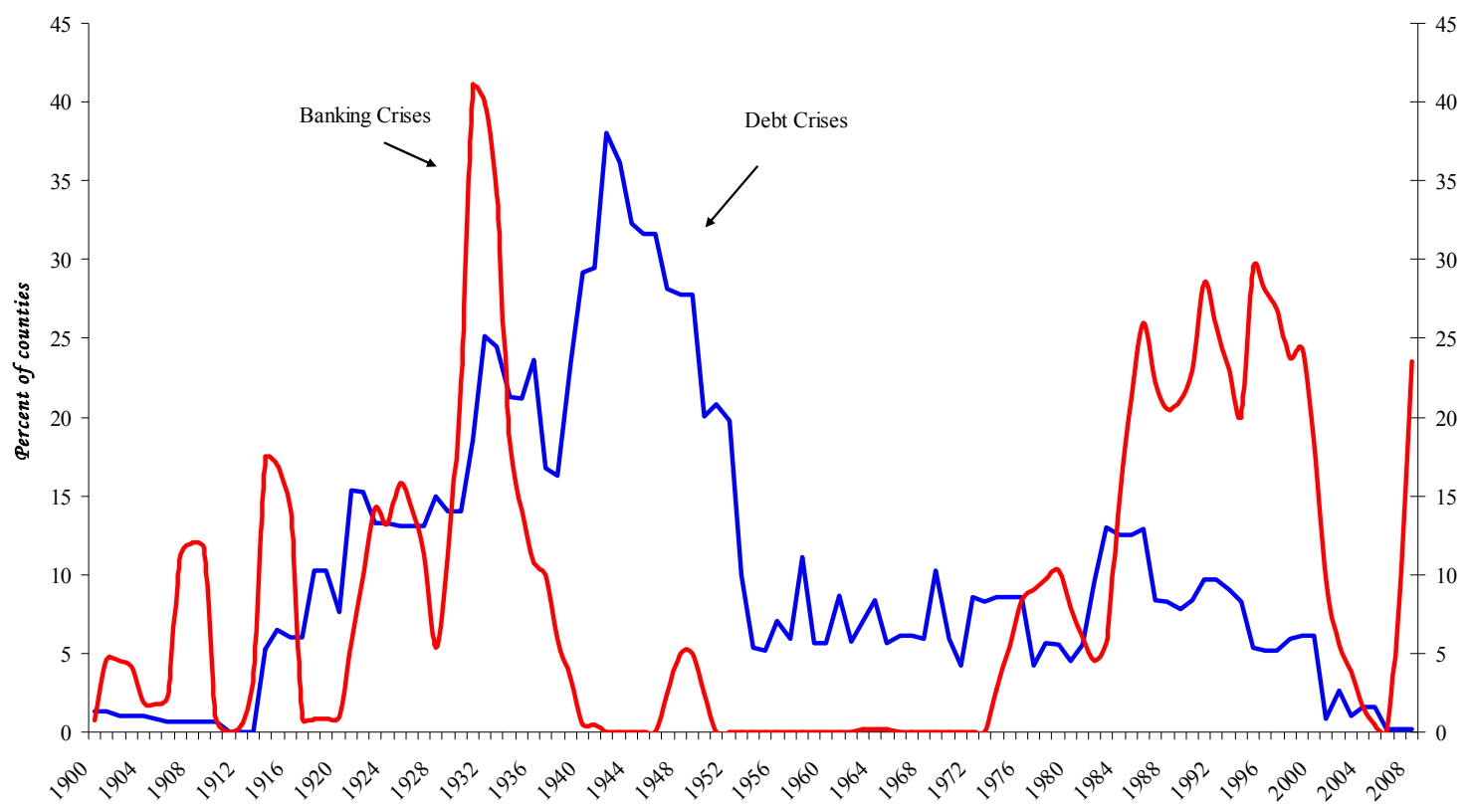

Sources: Bordo et al. (2001), Caprio et al. (2005), Jácome (2008), Kaminsky and Reinhart (1999), Lindert and Morton (1989), Macdonald (2003), Maddison (2003), Purcell and Kaufman (1993), Reinhart, Rogoff, and Savastano (2003), Suter (1992), and Standard and Poor's (various years).

Notes: Sample size includes all countries, out of a total of sixty-six listed in Table 1 that were independent states in the given year. Three sets of GDP weights are used, 1913 weights for the period 1800-1913, 1990 for the period 1914-1990, and finally 2003 weights for the period 1991-2006. The entries for 2007-2008 list crises in Austria, Belgium, Germany, Hungary, Japan, the Netherlands, Spain, the United Kingdom, and the United States. The figure shows a three-year moving average. 


\section{Banking Crises: An Equal Opportunity Menace}

In earlier papers, we have shown that the frequency of a default (or restructuring) on external debt is significantly lower for advanced economies than for emerging markets. For many high-income countries, that frequency has effectively been zero since $1800{ }^{15}$ Even countries with a long history of multiple defaults prior to 1800 , countries such as France and Spain, present evidence of having "graduated" from serial default on external debt.

The second column in Tables 1 and 2 highlights the vast differences between emerging markets (notably in Africa and in Latin America-but even in several countries in Asia) and high-income Western Europe, North America and Oceania. The third column of Tables 1 and 2 present the analogous calculation for each country for banking crises (i.e., number of years in banking crises, according to the extended dataset developed here, divided by the number of years since independence or since 1800 - if independence was earlier). One striking observation from Tables 1 and 2 is that the average length of time spent in a state of sovereign default is far above the average amount of time spent in a financial crisis. A country can circumvent its external creditors for an extended period. It is far more costly to leave a domestic banking crisis hanging, due to the crippling effects on trade and investment.

\footnotetext{
${ }^{15}$ We do recognize, however, that the wide-spread abrogation of gold clauses — on domestic debt — during the 1930s' Great Depression by the United States and other developed economies were de facto sovereign defaults
} 
Table 1. Debt and Banking Crises: Africa and Asia, Year of Independence-2008

\begin{tabular}{|c|c|c|}
\hline Country & $\begin{array}{l}\text { Share of years in default } \\
\text { or rescheduling since } \\
\text { independence or } 1800\end{array}$ & $\begin{array}{l}\text { Share of years in a } \\
\text { banking crisis since } \\
\text { independence or } 1800\end{array}$ \\
\hline \multicolumn{3}{|l|}{ Africa } \\
\hline Algeria & 13.3 & 6.4 \\
\hline Angola & 59.4 & 17.6 \\
\hline Central African Republic & 53.2 & 38.8 \\
\hline Cote D'Ivoire & 48.9 & 8.2 \\
\hline Egypt & 3.4 & 5.6 \\
\hline Kenya & 13.6 & 19.6 \\
\hline Mauritius & 0.0 & 2.4 \\
\hline Morocco & 15.7 & 3.8 \\
\hline Nigeria & 21.3 & 10.2 \\
\hline South Africa & 5.2 & 6.3 \\
\hline Tunisia & 9.6 & 9.6 \\
\hline Zambia & 27.9 & 2.2 \\
\hline Zimbabwe & 40.5 & 27.3 \\
\hline \multicolumn{3}{|l|}{ Asia } \\
\hline China & 13.0 & 9.1 \\
\hline India & 11.7 & 8.6 \\
\hline Indonesia & 15.5 & 13.3 \\
\hline Japan & 5.3 & 8.1 \\
\hline Korea & 0.0 & 17.2 \\
\hline Malaysia & 0.0 & 17.3 \\
\hline Myanmar & 8.5 & 13.1 \\
\hline Philippines & 16.4 & 19.0 \\
\hline Singapore & 0.0 & 2.3 \\
\hline Sri Lanka & 6.8 & 8.2 \\
\hline Taiwan & 0.0 & 11.7 \\
\hline Thailand & 0.0 & 6.7 \\
\hline
\end{tabular}

${ }^{1}$ For countries that became independent prior to 1800 the calculations are for 1800-2006.

Sources: Authors' calculations, Bordo et al. (2001), Caprio et al. (2005), Kaminsky and Reinhart (1999), Jácome (2008), Standard and Poor's, Purcell and Kaufman (1993), Reinhart, Rogoff and Savastano (2003) and sources cited therein. See also Appendix II. 
Table 2. Debt and Banking Crises: Europe, Latin America, North America, and Oceania, Year of Independence-2008

\begin{tabular}{|c|c|c|}
\hline Country & $\begin{array}{l}\text { Share of years in default } \\
\text { or rescheduling since } \\
\text { independence or } 1800\end{array}$ & $\begin{array}{l}\text { Share of years in a } \\
\text { banking crisis since } \\
\text { independence or } 1800\end{array}$ \\
\hline \multicolumn{3}{|l|}{ Europe } \\
\hline Austria & 17.4 & 1.9 \\
\hline Belgium & 0.0 & 7.3 \\
\hline Denmark & 0.0 & 7.2 \\
\hline Finland & 0.0 & 8.7 \\
\hline France & 0.0 & 11.5 \\
\hline Germany & 13.0 & 6.2 \\
\hline Greece & 50.6 & 4.4 \\
\hline Hungary & 37.1 & 6.6 \\
\hline Italy & 3.4 & 8.7 \\
\hline Netherlands & 6.3 & 1.9 \\
\hline Norway & 0.0 & 15.7 \\
\hline Poland & 32.6 & 5.6 \\
\hline Portugal & 10.6 & 2.4 \\
\hline Romania & 23.3 & 7.8 \\
\hline Russia & 39.1 & 1.0 \\
\hline Spain & 23.7 & 8.1 \\
\hline Sweden & 0.0 & 4.8 \\
\hline Turkey & 15.5 & 2.4 \\
\hline United Kingdom & 0.0 & 9.2 \\
\hline \multicolumn{3}{|l|}{ Latin America } \\
\hline Argentina & 32.5 & 8.8 \\
\hline Bolivia & 22.0 & 4.3 \\
\hline Brazil & 25.4 & 9.1 \\
\hline Chile & 27.5 & 5.3 \\
\hline Colombia & 36.2 & 3.7 \\
\hline Costa Rica & 38.2 & 2.7 \\
\hline Dominican Republic & 29.0 & 1.2 \\
\hline Ecuador & 58.2 & 5.6 \\
\hline El Salvador & 26.3 & 1.1 \\
\hline Guatemala & 34.4 & 1.6 \\
\hline Honduras & 64.0 & 1.1 \\
\hline Mexico & 44.6 & 9.7 \\
\hline Nicaragua & 45.2 & 5.4 \\
\hline Panama & 27.9 & 1.9 \\
\hline Paraguay & 23.0 & 3.1 \\
\hline Peru & 40.3 & 4.3 \\
\hline Uruguay & 12.8 & 3.1 \\
\hline Venezuela & 38.4 & 6.2 \\
\hline \multicolumn{3}{|l|}{ North America } \\
\hline Canada & 0.0 & 8.5 \\
\hline United States & 0.0 & 13.0 \\
\hline \multicolumn{3}{|l|}{ Oceania } \\
\hline Australia & 0.0 & 5.7 \\
\hline New Zealand & 0.0 & 4.0 \\
\hline
\end{tabular}

Sources: Authors' calculations, Bordo et al. (2001), Caprio et al. (2005), Kaminsky and Reinhart (1999), Jácome (2008), Standard and Poor's, Purcell and Kaufman (1993), Reinhart, Rogoff and Savastano (2003) and sources cited therein. See also Appendix II. 
Tables 3 and 4 present a different perspective on the prevalence of banking crises. The second column tallies the number of banking crises (rather than the number of years in crisis) since independence or 1800; while the third narrows the window to the post-WWII period. Several features are worth noting. For the advanced economies during the full sample, the picture that emerges is one of serial banking crises. The world's financial centers, the United Kingdom, the United States and France stand out in this regard, with 12, 13, and 15 banking crisis episodes, respectively. The frequency of banking crises drops off markedly for the advanced economies and the larger emerging markets alike during post-WWII. However, all except Portugal experienced at least one post-War crisis prior to the current episode. When the present wave of crises is fully factored in, the apparent drop will likely be even less pronounced. Thus, while many now-advanced economies have graduated from a history of serial default on sovereign debt, or very high inflation (above 20 percent), graduation from banking crises has proven, so far, virtually impossible. Indeed, Tables 1-4 illustrate that despite dramatic differences in recent sovereign default performance, the incidence of banking crises is about the same for advanced economies as for emerging markets. It also should be noted that as financial markets have developed in the smaller, poorer economies, the frequency of banking crises has increased. $^{16}$

\footnotetext{
${ }^{16}$ As we have already acknowledged, our accounting of financial crises in poorer countries may be incomplete, especially for earlier periods, despite our best efforts.
} 
Table 3. Frequency of Banking Crises: Africa and Asia through 2008

\begin{tabular}{lll}
\hline \hline Country & $\begin{array}{l}\text { Number of banking } \\
\text { crises since } \\
\text { independence or } 1800\end{array}$ & $\begin{array}{l}\text { Number of banking } \\
\text { crises since } \\
\text { independence or } 1945\end{array}$ \\
\hline
\end{tabular}

Africa
Algeria
Angola
Central African Republic
Cote D'Ivoire
Egypt
Kenya
Mauritius
Morocco
Nigeria
South Africa ${ }^{1}$
Tunisia
Zambia
Zimbabwe
Asia
China
India ${ }^{1}$
Indonesia
Japan
Korea
Malaysia
Myanmar
Philippines
Singapore
Sri Lanka
Taiwan ${ }^{1}$
Thailand

$\begin{array}{ll}1 & 1 \\ 1 & 1 \\ 2 & 2 \\ 1 & 1 \\ 3 & 1 \\ 2 & 2 \\ 1 & 2 \\ 1 & 1 \\ 1 & 1 \\ 6 & 1 \\ 1 & 2 \\ 1 & 1 \\ 1 & 1 \\ & 1\end{array}$

${ }^{1}$ For South Africa the calculations are for 1850-2008; for India these are for 1800-2008.

Sources: Authors' calculations, Bordo et al. (2001), Caprio et al. (2005), Kaminsky and Reinhart (1999), and Jácome (2008). See also Appendix II. 
Table 4. Frequency of Banking Crises: Europe, Latin America, North America, and Oceania, Through 2008

\begin{tabular}{|c|c|c|}
\hline Country & $\begin{array}{l}\text { Number of banking } \\
\text { crises since } \\
\text { independence or } 1800\end{array}$ & $\begin{array}{l}\text { Number of banking } \\
\text { crises since } \\
\text { independence or } 1945\end{array}$ \\
\hline \multicolumn{3}{|l|}{ Europe } \\
\hline Austria & 3 & 1 \\
\hline Belgium & 10 & 1 \\
\hline Denmark & 10 & 1 \\
\hline Finland & 5 & 1 \\
\hline France & 15 & 1 \\
\hline Germany & 8 & 2 \\
\hline Greece & 2 & 1 \\
\hline Hungary & 2 & 2 \\
\hline Italy & 11 & 1 \\
\hline Netherlands & 4 & 1 \\
\hline Norway & 6 & 1 \\
\hline Poland & 1 & 1 \\
\hline Portugal & 5 & 0 \\
\hline Romania & 1 & 1 \\
\hline Russia & 2 & 2 \\
\hline Spain & 8 & 2 \\
\hline Sweden & 5 & 1 \\
\hline Turkey & 2 & 2 \\
\hline United Kingdom & 12 & 4 \\
\hline \multicolumn{3}{|l|}{ Latin America } \\
\hline Argentina & 9 & 4 \\
\hline Bolivia & 3 & 3 \\
\hline Brazil & 11 & 3 \\
\hline Chile & 7 & 2 \\
\hline Colombia & 2 & 2 \\
\hline Costa Rica & 2 & 2 \\
\hline Dominican Republic & 2 & 2 \\
\hline Ecuador & 2 & 2 \\
\hline El Salvador & 2 & 2 \\
\hline Guatemala & 3 & 2 \\
\hline Honduras & 1 & 1 \\
\hline Mexico & 7 & 2 \\
\hline Nicaragua & 1 & 1 \\
\hline Panama & 1 & 1 \\
\hline Paraguay & 2 & 1 \\
\hline Peru & 3 & 1 \\
\hline Uruguay & 5 & 2 \\
\hline Venezuela & 2 & 2 \\
\hline \multicolumn{3}{|l|}{ North America } \\
\hline Canada & 8 & 1 \\
\hline United States & 13 & 2 \\
\hline \multicolumn{3}{|l|}{ Oceania } \\
\hline Australia & 3 & 2 \\
\hline New Zealand & 1 & 1 \\
\hline
\end{tabular}

${ }^{1}$ For countries that became independent prior to 1800 the calculations are for 1800-2006.

Sources: Authors' calculations, Bordo et al. (2001), Caprio et al. (2005), Kaminsky and Reinhart (1999), and Jácome (2008). See also Appendix II. 


\section{Summary Tables by Region of Frequency of Banking Crises, 1800-2007, and 1945-2007}

Tables $5 \mathrm{a}$ and $5 \mathrm{~b}$ summarize, by region, the evidence on the number of banking crises and share of years in banking crisis. Table 5a starts in 1800. (The table only includes post independence crises, which explains why emerging markets have lower cumulative totals since 1800.) Table $5 \mathrm{~b}$ gives the evidence for post- 1945 .

Table 5a: Summary on the Incidence and Frequency of Banking Crises: 1800 (or independence)-2008

\begin{tabular}{lcc}
\hline \hline Region/Group & $\begin{array}{c}\text { Share of years in a banking crisis } \\
\text { since independence or 1800 }\end{array}$ & Number of banking crises \\
\hline Africa & 12.5 & 1.7 \\
Asia & 11.2 & 3.6 \\
Europe & 6.3 & 5.9 \\
Latin America & 4.4 & 3.6 \\
Of which: Argentina, Brazil, and & 9.2 & 9.0 \\
Mexico & 11.2 & 10.5 \\
North America & 4.8 & 2.0 \\
Oceania & 7.2 & 7.2 \\
Advanced & 8.3 & 2.8 \\
Emerging & & \\
\hline
\end{tabular}

Table 5b: Summary on the Incidence and Frequency of Banking Crises: 1945 (or independence)-2008

\begin{tabular}{lcc}
\hline \hline Region/Group & $\begin{array}{c}\text { Share of years in a banking crisis } \\
\text { since independence or 1800 }\end{array}$ & Number of banking crises \\
\hline Africa & 12.3 & 1.3 \\
Asia & 12.4 & 1.8 \\
Europe & 7.1 & 1.4 \\
Latin America & 9.7 & 2.0 \\
Of which: Argentina, Brazil, and & 13.5 & 3.0 \\
Mexico & & \\
North America & 8.6 & 1.5 \\
Oceania & 7.0 & 1.5 \\
Advanced & 7.0 & 1.4 \\
Emerging & 10.8 & 1.7 \\
\hline \hline
\end{tabular}

Notes: Advanced economies are comprised of North America, Oceania, Japan and all European countries not listed below as part of emerging Europe. Emerging economies consist of Africa, all Asian countries except Japan, Latin America, and emerging Europe (Hungary, Poland, Romania, Russia, and Turkey).

Sources: based on Tables $1-4$. 
Whether the calculations are done from 1800 (Table 5a) or from 1945 (Table 5b), on average there are no significant differences in either the incidence or number of banking crises between advanced and emerging economies—banking crises are an equal opportunity

menace. In fact, prior to WWII the advanced economies with their more developed financial systems were more prone to banking crises than many of the smaller low income counterparts. ${ }^{17}$

\section{The Bunching of Banking Crises: Contagion or Common Fundamentals?}

In this section, we discuss the bunching of banking crises across countries that is so evident in the late-2000s case, where both common shocks (the bursting of the global housing bubble) and cross-country linkages (for example, because many countries bought U.S. subprime mortgage debt) are evident.

Bordo and Murshid (2001) and Neal and Weidenmier (2003) have pointed out that crosscountry correlations in banking crises were also common during 1880-1913, a period of relatively high international capital mobility under the gold standard. ${ }^{18}$ Table 6 looks at a broader time span including the twentieth century; the table lists the years during which banking crises are bunched; greater detail on individual country dates is provided in Appendix A3. ${ }^{19}$ The famous Baring crisis of 1890 (which involved Argentina and the U.K. before spreading elsewhere) appears to be the first episode of international bunching of banking crises; this was followed by the panic of 1907, which began in the United States and quickly spread to other

\footnotetext{
${ }^{17}$ On average, 7.2 crises for the advanced versus 2.8 for the emerging market countries (Table 5a).

${ }^{18}$ Bordo and Murshid (2001) look at the period 1880-1913. Neal and Weidenmier (2003) emphasize that periods of apparent contagion can be more readily interpreted as responses to common shocks, an issue we return to in the context of the present crisis. But, perhaps, the bottom line as regards a historical perspective on financial contagion is best summarized by Bordo and Murshid (2001), who conclude that "there is little evidence to suggest that crosscountry linkages are tighter in the aftermath of a financial crisis for the recent period" (as opposed to 1880-1913, the earlier heyday of globalization in financial markets that they study).

${ }^{19}$ Table 6 does not include the bunching of other "types" of crises, such as the wave of sovereign defaults during 1825 or the currency crashes/debasements of the Napoleonic Wars.
} 
advanced economies (particularly, Denmark, France, Italy, Japan, and Sweden). These episodes are reasonable benchmarks for modern-day financial contagion. ${ }^{20}$

Of course, other pre-World War II episodes of banking crisis contagion pale when confronted with the Great Depression (which also saw a large bunching in sovereign debt defaults, as seen earlier in Figure 2).

${ }^{20}$ See, Neal and Weidenmeir (2003) and Reinhart and Rogoff (2008a). 
Table 6. Global Banking Crises, 1890-2008:

Contagion or Common Fundamentals?

\begin{tabular}{|c|c|c|}
\hline $\begin{array}{l}\text { Years of bunching in banking } \\
\text { crises }\end{array}$ & Affected countries & Comments \\
\hline $1890-1891$ & $\begin{array}{l}\text { Argentina, Brazil, Chile, } \\
\text { Portugal, UK, and US }\end{array}$ & $\begin{array}{l}\text { Argentina defaults and there are } \\
\text { runs on all Argentine banks (see } \\
\text { della Paolera and Taylor (2001); } \\
\text { Baring Brothers faces failure. }\end{array}$ \\
\hline 1907-1908 & $\begin{array}{l}\text { Chile, Denmark, France, Italy, } \\
\text { Japan, Mexico, Sweden, US }\end{array}$ & $\begin{array}{l}\text { A fall in copper prices } \\
\text { undermines the solvency of a } \\
\text { trust company (quasi bank) in } \\
\text { NewYork. }\end{array}$ \\
\hline 1914 & $\begin{array}{l}\text { Argentina, Belgium, Brazil, } \\
\text { France, India, Italy, Japan, } \\
\text { Netherlands, Norway, UK, and } \\
\text { US }\end{array}$ & The outbreak of WWI \\
\hline 1929-1931 & $\begin{array}{l}\text { Advanced: Belgium, Finland, } \\
\text { France, Germany, Greece, Italy, } \\
\text { Portugal, Spain, Sweden, US } \\
\text { Emerging markets: Argentina, } \\
\text { Brazil, China, India, Mexico }\end{array}$ & $\begin{array}{l}\text { Real commodity prices collapse } \\
\text { by about } 51 \text { percent during } 1928- \\
1931 . \text { Real interest rates reach } \\
\text { almost } 13 \text { percent in the US. }\end{array}$ \\
\hline 1981-1982 & $\begin{array}{l}\text { Emerging markets: Argentina, } \\
\text { Chile, Colombia, Congo, } \\
\text { Ecuador, Egypt, Ghana, Mexico, } \\
\text { the Philippines, Turkey, and } \\
\text { Uruguay }\end{array}$ & $\begin{array}{l}\text { Between } 1979 \text { and } 1982 \text {, real } \\
\text { commodity prices fall about } 40 \\
\text { percent. US real interest rates hit } \\
\text { about } 6 \text { percent-their highest } \\
\text { readings since } 1933 \text {. The } \\
\text { beginning of the decade-long debt } \\
\text { crisis in emerging markets. }\end{array}$ \\
\hline $1987-1988$ & $\begin{array}{l}\text { Many small, mostly low-income } \\
\text { countries, Sub-Saharan Africa- } \\
\text { particularly hard hit. }\end{array}$ & $\begin{array}{l}\text { The tail-end of a nearly decade- } \\
\text { long debt crisis. }\end{array}$ \\
\hline 1991-1992 & $\begin{array}{l}\text { Advanced: Czech Republic, } \\
\text { Finland, Greece, Japan, Sweden } \\
\text { Others: Algeria, Brazil, Egypt, } \\
\text { Georgia, Hungary, Poland, } \\
\text { Romania, Slovak Republic }\end{array}$ & $\begin{array}{l}\text { Real estate and equity price } \\
\text { bubbles in the Nordic countries } \\
\text { and Japan burst; many transition } \\
\text { economies cope with } \\
\text { liberalization and stabilization. }\end{array}$ \\
\hline 1994-1995 & $\begin{array}{l}\text { Argentina, Bolivia, Brazil, } \\
\text { Ecuador, Mexico, and Paraguay } \\
\text { Others: Azerbaijan, Croatia, } \\
\text { Cameroon, Lithuania, Swaziland }\end{array}$ & $\begin{array}{l}\text { The Mexican "tequila" crisis } \\
\text { deals the first blow to the surge in } \\
\text { capital inflows to emerging } \\
\text { markets since the early } 1990 \mathrm{~s} \text {. }\end{array}$ \\
\hline 1997-1998 & $\begin{array}{l}\text { Asia: Hong Kong, Indonesia, } \\
\text { Malaysia, Philippines, Taiwan, } \\
\text { Thailand, and Vietnam } \\
\text { Others: Colombia, Ecuador, El } \\
\text { Salvador, Mauritius, Russia, } \\
\text { Ukraine }\end{array}$ & $\begin{array}{l}\text { The second and last blow to } \\
\text { capital flows to merging markets }\end{array}$ \\
\hline 2007--present & $\begin{array}{l}\text { Germany, Hungary, Iceland, } \\
\text { Ireland, Japan, Spain, UK, US } \\
\text { and others }\end{array}$ & $\begin{array}{l}\text { The US subprime real estate } \\
\text { bubble-and other real estate } \\
\text { bubbles in advance economies }\end{array}$ \\
\hline
\end{tabular}




\section{The Late 2000s Global Financial Crisis}

The current conjuncture is illustrative of the two channels of contagion, linkages and common shocks. There is little doubt that the U.S. crisis has spilled over into other markets through direct linkages. For example, German and Japanese financial institutions (and others ranging as far as Kazakhstan) sought more attractive returns in the U.S. subprime market, perhaps owing to the fact that profit opportunities in domestic real estate were limited at best and dismal at worst (Figure 3). Indeed, after the fact, it has become evident that many financial institutions outside the United States had nontrivial exposure to the U.S. subprime market. ${ }^{21}$ This is a classic channel of transmission or contagion, through which a crisis in one country spreads across international borders. In the present context, however, contagion or spillovers are only part of the story.

That many other countries are experiencing economic difficulties at the same time as the United States also owes importantly to the fact that many of the features that characterized the run-up to the subprime crisis in the United States were present in many other advanced economies. Specifically, many countries in Europe and elsewhere (New Zealand, for example) were having their own home-grown real estate bubbles (Figure 3). This, in and of itself, makes these countries vulnerable to the usual nasty consequences of asset market crashes-irrespective of what may be happening in the United States.

\footnotetext{
${ }^{21}$ Owing to the opaqueness of balance sheets in many financial institutions in these countries, the full extent of exposure is, as yet, unknown.
} 
Figure 3

\section{Percent Change in Real Housing Prices: \\ 2002-2006}

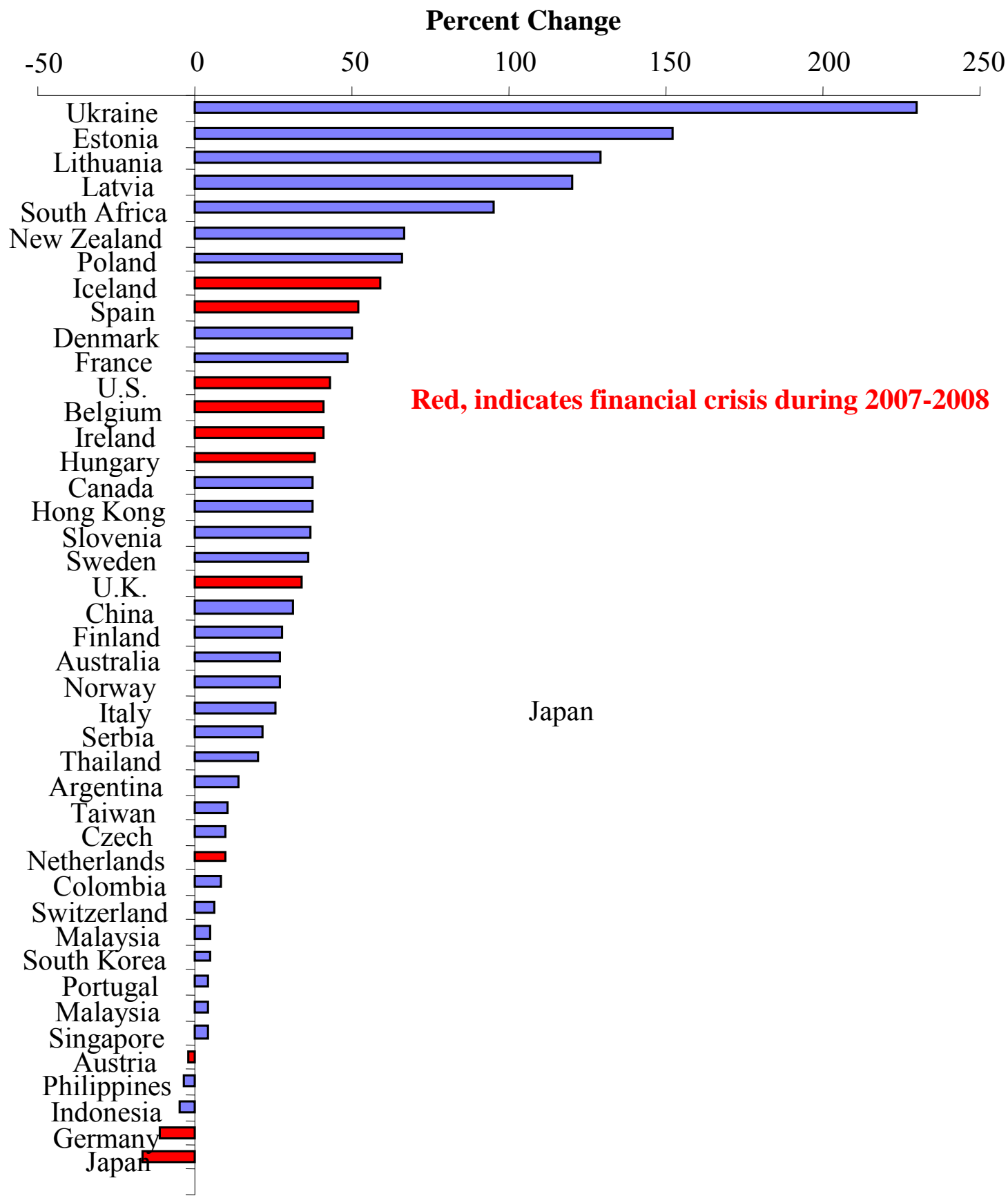

Sources: Bank of International Settlements and sources listed in Table A4. China data covers 2003-2006. 


\section{Banking Crises, Capital Mobility, And Financial Liberalization}

Also consonant with the modern theory of crises is the striking correlation between freer capital mobility and the incidence of banking crises, as shown in Figure 4. Periods of high international capital mobility have repeatedly produced international banking crises, not only famously as they did in the 1990s, but historically. The figure plots a three-year moving average of the share of all countries experiencing banking crises on the right scale. On the left scale, we graph the index of capital mobility, due to Obstfeld and Taylor (2004), updated and back cast using their same design principle, to cover our full sample period. While the ObstfeldTaylor index may have its limitations, we feel it nevertheless provides a concise summary of complicated forces by emphasizing de facto capital mobility based on actual flows.

For the post-1970 period, Kaminsky and Reinhart (1999) present formal evidence on the links of crises with financial liberalization. In 18 of the 26 banking crises they study, the financial sector had been liberalized within the preceding five years, usually less. In the 1980s and 1990s most liberalization episodes were associated with financial crises of varying severity. Only in a handful of countries (for instance, Canada) did financial sector liberalization proceed smoothly. Specifically, the paper presents evidence that the probability of a banking crisis conditional on financial liberalization having taken place is higher than the unconditional probability of a banking crisis; probit analysis confirmed these results. Using a 53-country sample for the period 1980-1995 Demirgüç-Kunt and Detragiache (1998) also show, in the context of a multivariate logit model, that financial liberalization has an independent negative effect on banking sector stability and that this result is robust across numerous specifications. ${ }^{22}$

\footnotetext{
${ }^{22}$ See also, Drees and Pazarbasioglu (1998) for an insightful discussion of the Nordic experience with financial liberalization.
} 
The stylized evidence presented in Caprio and Klingebiel (1996) suggests that inadequate regulation and lack of supervision at the time of the liberalization may play a key role in explaining why deregulation and banking crises are so closely entwined. Again, this is a theme across developed countries and emerging markets alike.

Figure 4

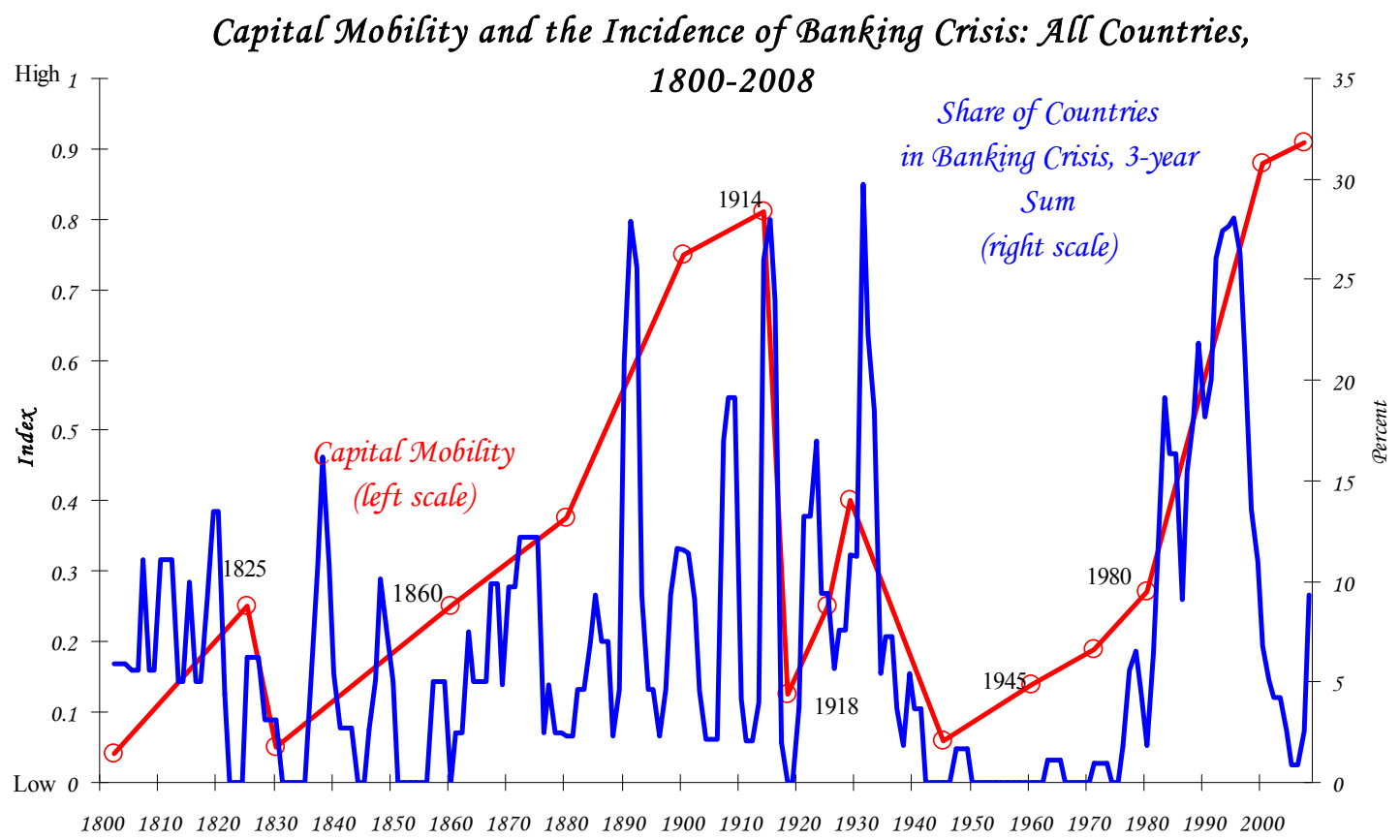

Sources: Bordo et al. (2001), Caprio et al. (2005), Kaminsky and Reinhart (1999), Obstfeld and Taylor (2004), and these authors.

Notes: This sample includes all countries (even those not in our core sample of 66). The full listing of banking crises dates are shown in Appendix II. On the left scale, we updated our favorite index of capital mobility, admittedly arbitrary, but a concise summary of complicated forces. The smooth red line shows the judgmental index of the extent of capital mobility given by Obstfeld and Taylor (2004), back cast from 1800 to 1859 using their same design principle. 


\section{Capital Flow Bonanzas, Credit Cycles and Asset Prices}

This section examines some of the common features of banking crises across countries, regions and time. The focus is on the regularities among cycles in international capital flows, credit, and asset prices (specifically, housing and equity prices).

\section{Capital flow bonanzas and crisis vulnerability}

One common characteristic of the run-up to banking crises is a sustained surge in capital inflows. Reinhart and Reinhart (2008) delineate a criterion to define a capital flow bonanza, catalogue (country-by-country) "bonanza" ${ }^{23}$ episodes for 1960-2006, and examined the links between bonanza spells and banking crises, employing the crisis dates defined and dated in the Appendix to the present paper. ${ }^{24}$

From the Appendix crises dates and the bonanza dates, two country-specific probabilities were calculated. The unconditional probability of a banking crisis, along the lines of those shown in Tables 1 and 2 (except for 1960-2007), and the probability of a banking crisis within a window of three years before and after the bonanza year or years - that is, as the conditional probability of a crisis. If capital flow bonanzas make countries more crises prone, the conditional probability, $\mathrm{P}(\mathrm{Crisis}$ | Bonanza) should be greater than the unconditional probability of a crisis, $\mathrm{P}($ Crisis $)$.

\footnotetext{
${ }^{23}$ Reinhart an Reinhart define a capital flow bonanza as follows They settled on an algorithm that provided uniform treatment across countries but was flexible enough to allow for significant cross-country variation in the current account. As in Kaminsky and Reinhart (1999), we select a threshold to define bonanzas that is common across countries (in this case the $20^{\text {th }}$ percentile). ${ }^{23}$ This threshold included most of the better known episodes in the literature but was not so inclusive as to label a bonanza more "routine" deteriorations in the current account. Because the underlying frequency distributions vary widely across countries, the common threshold produces quite disperse country-specific cutoffs. For instance, in the case of relatively closed India, the cutoff to define a bonanza is a current account deficit/GDP in excess of 1.8 percent, while for trade-oriented Malaysia the comparable cutoff is a deficit/GDP ratio of 6.6 percent. ${ }^{23} .^{23}$

${ }^{24}$ They performed a comparable exercise for currency, debt, and inflation crises.
} 
Table 7 reproduces a subset of the results a Reinhart and Reinhart for banking crises. It presents aggregates of the country-specific conditional and unconditional probabilities for three groups (all countries, high income, and middle and low income).

\section{The probability of a banking crisis conditional on a capital flow bonanza is higher than the}

unconditional probability. The bottom row of Table 6 provides the share of countries for which $\mathrm{P}($ Crisis $\mid$ Bonanza $) \geq \mathrm{P}($ Crisis $)$ as an additional indication of how common place is it across countries to see bonanzas associated with a more crisis-prone environment. For banking crises, the majority of countries (61 percent) register a higher propensity to banking crises around bonanza periods.

We conjecture that the 61 percent figure would be higher if one were to include post2007 data in Table 7. Many countries experiencing the most severe banking crises have also run large sustained current account deficits. These include many developed countries, such as the United States, the United Kingdom, Spain, Iceland and Ireland.

Table 7. Are Capital Flow Bonanza Episodes More Prone to Banking Crisis? 1960-2007

\begin{tabular}{cr}
\hline \multicolumn{2}{c}{ Probability of a banking crisis (in percent), 66-country sample } \\
\hline Conditional on a bonanza (three-year window) & 18.4 \\
Unconditional & 13.2 \\
Difference & 5.2 \\
\hline
\end{tabular}

Percent of countries for which conditional probability is greater than

60.9 unconditional

Notes: The three-year window encompasses three years before the bonanza years (see Reinhart and Reinhart, 2008, Table 2), the year (or years if these are consecutive) of the bonanza, and the three years following the episode. Italics denote significance at the one-percent confidence level.

Source: Reinhart and Reinhart (2008), based on Tables 2 and 4 and authors' calculations.

The findings on capital flow bonanzas in Reinhart and Reinhart (2008) are also consistent with empirical regularities surrounding credit cycles. Mendoza and Terrones (2008), who examine cycles in credit in both advanced and emerging market economies using a very different 
approach from that just discussed, find that credit booms in emerging market economies are often preceded by surges in capital inflows. They also conclude that while not all credit booms end in financial crises, most emerging market crises were preceded by credit booms. They link credit booms to rising asset prices, an issue we turn to next. ${ }^{25}$

\section{Equity and housing price cycles and banking crises}

In this section, we summarize the literature on asset price bubbles and banking crises, extending it to incorporate new data on housing prices in emerging markets, as well as data on the unfolding crises in the advanced economies.

The now-infamous real estate bubble in the United States that began to deflate at the end of 2005 occupies center stage as a culprit of the present financial crisis. But the subprime episode is far from unique in that regard. In Reinhart and Rogoff (2008b), we document the trajectory in real housing prices around all the post-WWII banking crises in advanced economies, with particular emphasis on the "Big 5" crises (Spain, 1977, Norway, 1987, Finland and Sweden, 1991 and Japan, 1992). ${ }^{26}$ The pattern that emerges is clear: a boom in real housing prices in the run-up to the crisis is followed by a marked decline the year of the crisis and in subsequent years. Bordo and Jeanne (2002), also studying the advanced economies during 1970-2001, find that banking crises tend to occur either at the peak of the boom in real housing prices, or right after the bust. Gerdrup (2003) presents a compelling narrative of the links between Norway's three banking crises during 1890s-1993 and the booms and busts in housing prices.

Table 8 illustrates the magnitude and duration of the downturn in housing prices that has historically accompanied major banking crises in both advanced and emerging economies.

\footnotetext{
${ }^{25}$ See also Kaminsky and Reinhart (1999), who also examine the growth in real credit to the private sector around both banking and currency crises.

${ }^{26}$ The years refer to the beginning of the crisis.
} 
While the links between banking crises and the housing price cycle have been examined in both our earlier work and numerous other papers (most frequently case studies), this is the first paper to provide systematic evidence on the behavior of housing prices for emerging market economies around some of their major banking crises. The crisis episodes include the "Big 6" Asian crises of 1997-1998, Indonesia, Korea, Malaysia, the Philippines, Thailand, and the much buffeted Hong Kong. 
Table 8. Real Housing Price Cycles and Banking Crises

\begin{tabular}{|c|c|c|c|c|c|}
\hline Country & Crisis date & Peak & Trough & $\begin{array}{l}\text { Duration of } \\
\text { downturn }\end{array}$ & $\begin{array}{l}\text { Magnitude of } \\
\text { decline } \\
\text { (in percent) }\end{array}$ \\
\hline \multicolumn{6}{|c|}{ Advanced economies: The Big 5} \\
\hline Finland & 1991 & 1989:Q2 & 1995:Q4 & 6 years & -50.4 \\
\hline Japan & 1992 & 1991:Q1 & Ongoing & Ongoing & -40.2 \\
\hline Norway & 1987 & 1987:Q2 & 1993:Q1 & 5 years & -41.5 \\
\hline Spain & 1977 & 1978 & 1982 & 4 years & -33.3 \\
\hline Sweden & 1991 & 1990:Q2 & 1994:Q4 & 4 years & -31.7 \\
\hline \multicolumn{6}{|c|}{ Asian Crisis: The Big 6} \\
\hline Hong Kong & 1997 & 1997:Q2 & 2003:Q2 & 6 years & -58.9 \\
\hline Indonesia & 1997 & 1994:Q1 & 1999:Q1 & 5 years & -49.9 \\
\hline Malaysia & 1997 & 1996 & 1999 & 3 years & -19.0 \\
\hline Philippines & 1997 & 1997:Q1 & 2004:Q3 & 7 years & -53.0 \\
\hline South Korea & 1997 & & 2001:Q2 & 4 years & -20.4 \\
\hline Thailand & 1997 & 1995:Q3 & 1999:Q4 & 4 years & -19.9 \\
\hline \multicolumn{6}{|c|}{ Other emerging } \\
\hline Argentina & 2001 & 1999 & 2003 & 4 years & -25.5 \\
\hline Colombia & 1998 & 1997:Q1 & 2003:Q2 & 6 years & -51.2 \\
\hline \multicolumn{6}{|c|}{ Historical episodes } \\
\hline Norway & 1898 & 1899 & 1905 & 6 years & -25.5 \\
\hline US & 1929 & 1925 & 1932 & 7 years & -12.6 \\
\hline \multicolumn{6}{|c|}{ Current cases } \\
\hline Hungary & 2008 & 2006 & Ongoing & Ongoing & -11.3 \\
\hline Iceland & 2007 & $\begin{array}{l}\text { November } \\
2007\end{array}$ & Ongoing & Ongoing & -9.2 \\
\hline Ireland & 2007 & October 2006 & Ongoing & Ongoing & -18.9 \\
\hline Spain & 2007 & 2007:Q1 & Ongoing & Ongoing & -3.1 \\
\hline UK & 2007 & October 2007 & Ongoing & Ongoing & -12.1 \\
\hline US & 2007 & $\begin{array}{l}\text { December } \\
2005\end{array}$ & & & -16.6 \\
\hline
\end{tabular}

Sources: Bank of International Settlements and the individual country sources described in the Data Appendix.

Other emerging market episodes include Argentina's mega-crisis in 2001-2002, and

Colombia's 1998 crisis, which produced the worst recession since the national income accounts were tabulated in the early 1920s. In the current conjuncture of unfolding crises, we include 
Hungary, in addition to the advanced economies that have had recent housing market bubbles (Iceland, Ireland, Spain, the United Kingdom, and the United States). ${ }^{27}$

Two features stand out from the summary statistics presented in Table 8. First is the persistence of the cycle in real housing prices in both advanced economies and emerging markets, typically four to six years. ${ }^{28}$ The second feature that stands out from Table 8 is that the magnitudes of the declines in real housing prices around banking crises from peak to trough are not appreciably different in emerging and advanced economies. This comparability is quite surprising given that most macroeconomic time series exhibit drastically greater volatility in emerging markets, and thus it merits further attention. ${ }^{29}$ Certainly, the first results presented here on comparing housing price booms and busts around banking crisis dates appears to strongly support the contention that banking crises are an equal opportunity menace.

The prolonged housing price downturns following financial crises are in stark contrast to the behavior of real equity prices, as illustrated in Figures $5 \mathrm{a}$ and $5 \mathrm{~b}$ in which the pattern of decline and recovery is more v-shaped.

\footnotetext{
${ }^{27}$ Historical comparisons are hard to come by, as most real housing price series are of recent vintage. We do include in this category two episodes: the United States during the Great Depression and Norway's crisis at the turn of the century (1898).

${ }^{28}$ See Ceron and Suarez (2006), who estimate its average duration at six years

${ }^{29}$ For example, Agenor, McDermott, and Prasad (2000) provide evidence that output and real consumption are far more volatile in emerging markets; Kaminsky, Reinhart and Vegh (2003) present evidence that the amplitude of the cycle in real government spending is orders of magnitude greater in emerging markets.
} 
Figure 5a

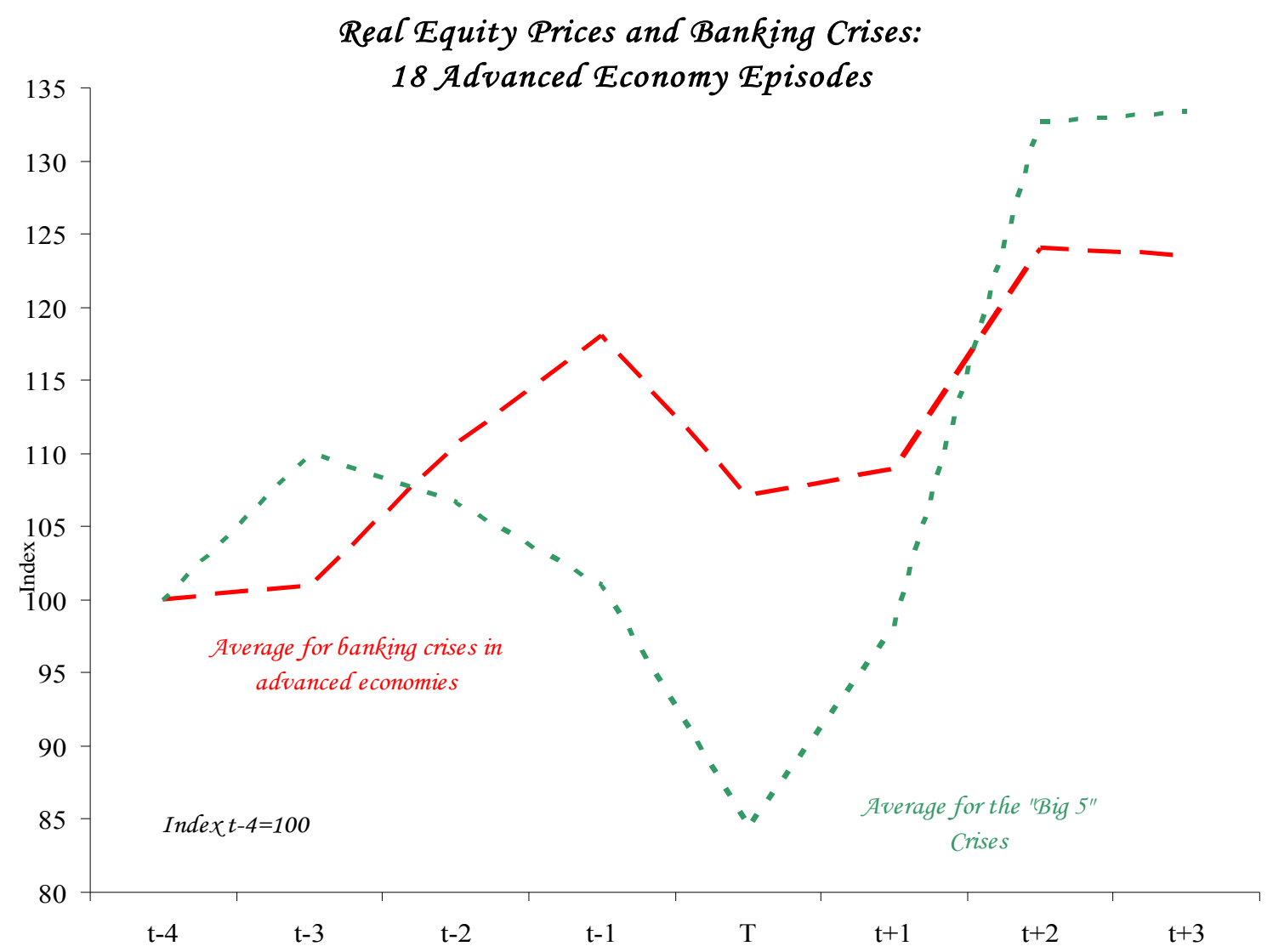

Notes: The Big 5 crises are: Spain, 1977; Norway, 1987; Finland, 1991, Sweden, 1991; and Japan 1992. Source: Global Financial Data and author's calculations. 
Figure $5 b$

\section{Equity Prices and Banking Crises: 40 Emerging Market Episodes}

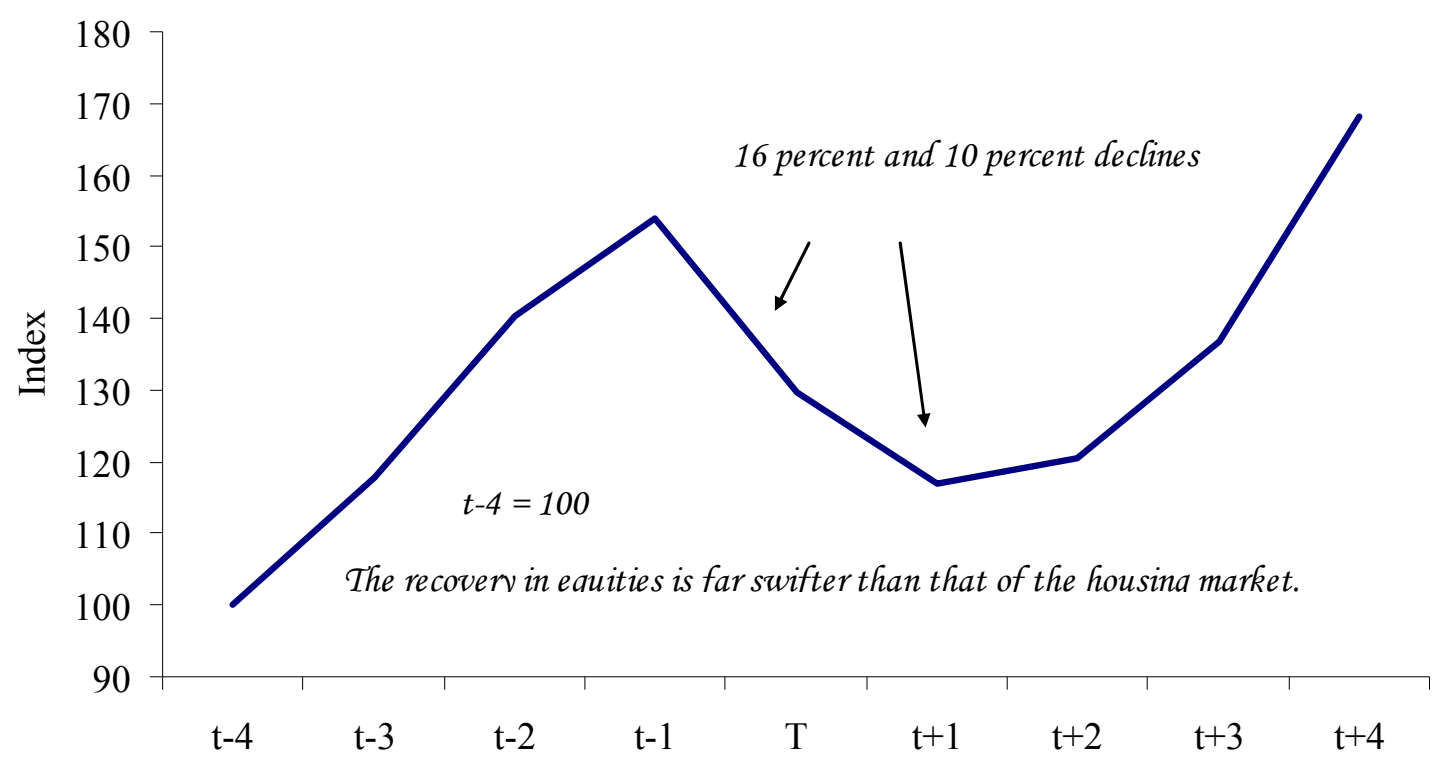

Source: Global Financial Data and author's calculations.

Notes: Four of the 40 episodes are pre-World War II (1921-1929). 
These figures show the evolution of real equity prices from four years prior to the crisis to three years afterwards for emerging and advanced economies separately. As the figures make plain, equity prices typically peak before the year of the banking crisis and decline for $2-3$ years as the crisis approaches and, in the case of emerging markets in the year following the crisis. However, the pattern tends to be v-shaped and the recovery complete, in the sense that three years after the crisis real equity prices are on average higher than the pre-crisis peak.

One can conjecture that one reason why major banking crises are such protracted affairs is that these episodes involve the real estate market's persistent cycle in a way that "pure stock market crashes" (for instance, Black Monday in October 1987 or the burst of the IT bubble in 2001) do not. ${ }^{30}$

\section{Financial Sector Expansion and Financial Crisis}

Philippon (2007) analyzes the expansion of the financial services sector (including insurance) in the United States, which averaged 4.9 percent of GDP during 1976-85, rising to 7.5 percent 1996-2005. His paper argues that this gain was not sustainable and a decline of at least 1 percent of GDP was probable. In the wake of the subprime crisis, the shrinkage of the financial sector during 2008 and 2009 is likely to be significantly larger. The pre-crisis explosion and post-collapse implosion of the financial sector surrounding a banking crisis is also not new or unique to the United States.

Figure 6 plots the number of banks in the United States in the run-up and aftermath of the Great Depression. Perhaps, the bubble in equity and real estate prices also extended to the number of financial institutions. This expansion in the run-up and contraction in the aftermath in

\footnotetext{
${ }^{30}$ This is consistent with the regularity that house prices are far more predictable (i.e., inertial) than equity prices.
} 
the number of financial institutions is evident during other banking crises -especially in those cases where financial liberalization preceded the banking crisis.

Figure 6

$\mathcal{N}$ umber of Banks in the US (1834-1945) and the Thousands International Spread of Banking Crisis, 1929-1931

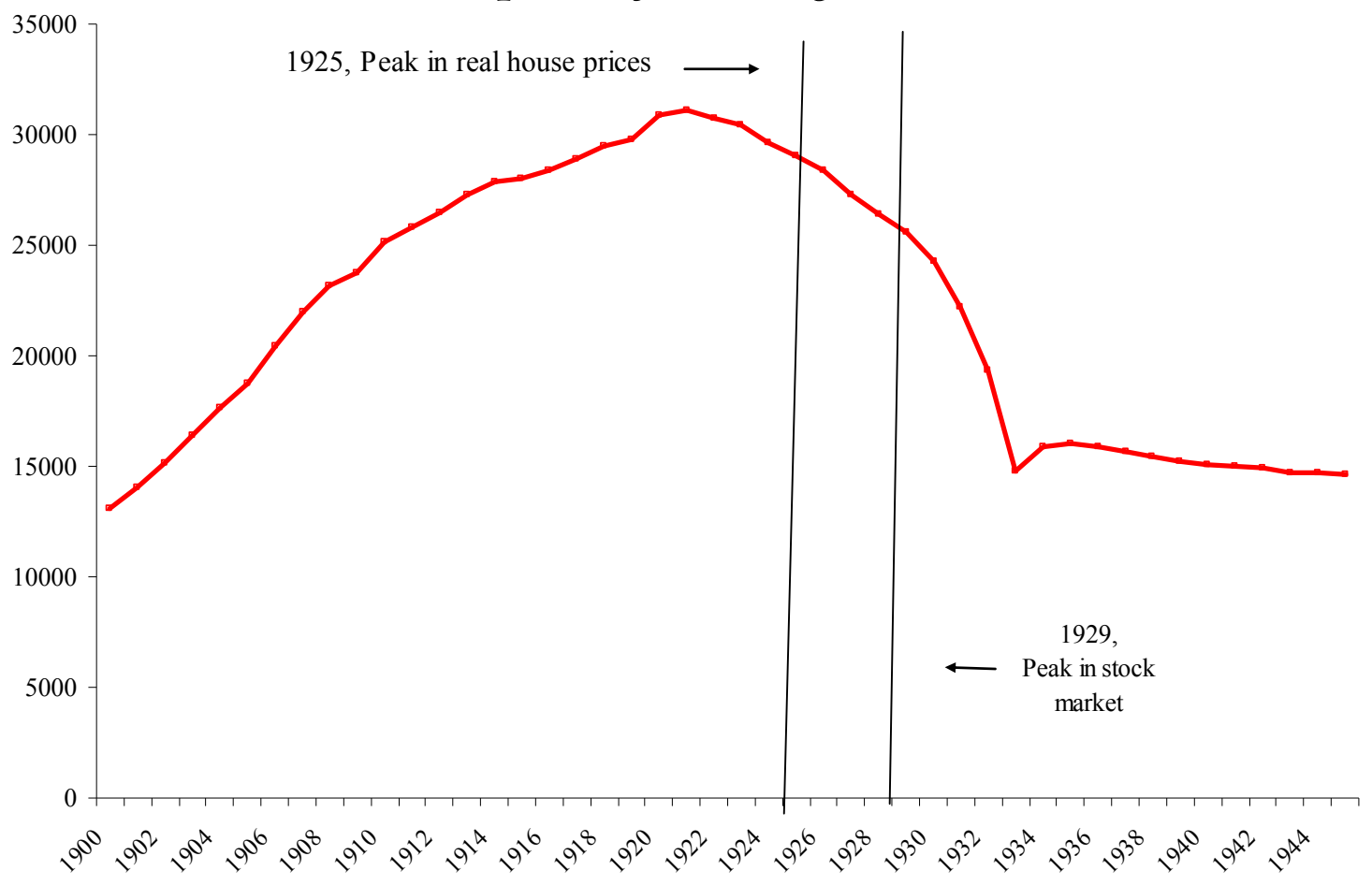

Sources: Historical Statistics of the Unites States.

33 


\section{The Fiscal and Growth Consequences of Banking Crises}

Looking at the fiscal and growth consequences of banking crises, we again find some surprising parallels between developed countries and emerging markets. Our analysis of the fiscal consequences, in particular, is a sharp departure from the previous literature, which has focused almost entirely on imputed "bailout costs" to the government which, as we shall argue, are extremely difficult to measure. Instead, we will focus on the fiscal costs to the government, particularly the huge build-ups in debt that follow banking crises. We are able to do so by tapping the extensive new cross-country annual dataset on domestic debt compiled in Reinhart and Rogoff (2008c). This data allow us to show the remarkable surge in debt that occurs in the wake of crises.

\section{That elusive concept of bailout costs}

As we have noted, much of the literature that studies banking crisis episodes is fixated on providing estimates of the fiscal or bailout costs of these crises (see, for example, an excellent discussion in Frydl, 1999, and various papers in Norges Bank, 2006). ${ }^{31}$ At the time of this writing, the International Monetary Fund estimates that the fiscal costs of the U.S. subprime crisis will tally about $\$ 1.4$ trillion, or around 11 percent of GDP. ${ }^{32}$ However, estimates of bailout costs vary markedly across studies, depending on the methodology and vary even more across time, depending on the length of horizon used to calculate the fiscal impact of the crisis, a point stressed in Frydl (1999). ${ }^{33}$ Table 9 presents the upper and lower bounds of estimates of the bailout costs for some of the better-known banking crises in both advanced and emerging economies in nearly all regions. The discrepancies across estimates are large and, in some cases,

\footnotetext{
${ }^{31}$ See also Caprio et al. (2005), and Hoggarth et al. (2002), and Sanhueza (2001).

${ }^{32}$ See International Monetary Fund, October 2008 World Economic Outlook and Global Financial Stability Report.

${ }^{33}$ A similar problem plagues work on determining the effectiveness of foreign exchange intervention by measuring the profitability of such market purchases or sales. The results depend importantly on the width of the time window and implicit assumptions of the cost of financing. See Neely (1995).
} 
staggering. Among the "Big 5" post-WWII crises in advanced economies, the differences in estimated bailout costs for Japan and Spain are 16 and 11 percent of GDP, respectively. Even for Norway, where the difference between the upper and lower bounds of the estimates is 2 percent of GDP, a different way of looking at the discrepancy is to note that the upper end of the estimates (4 percent of GDP) is twice as large as the lower bound estimates of the costs of the bailout. Furthermore, as noted in Vale (2006), if the costs are calculated over a longer time horizon after the crisis, the picture that emerges is even more at odds with the higher-end estimates; it shows that the Norwegian government actually made a small profit on the banking resolution, due to the later sale of shares in the nationalized banks.

Table 9. Creative Accounting? Bailout Costs of Banking Crises

\begin{tabular}{lccc} 
& Upper bound & Lower bound & Difference \\
\hline Argentina, 1981 & 55.3 & 4.0 & 51.3 \\
Chile, 1981 & 41.2 & 29.0 & 12.2 \\
Ghana, 1982 & 6.0 & 3.0 & 3.0 \\
Japan, 1992 & 24.0 & 8.0 & 16.0 \\
Norway, 1987 & 4.0 & 2.0 & 2.0 \\
Philippines 1984 & 13.2 & 3.0 & 10.2 \\
Spain, 1977 & 16.8 & 5.6 & 11.2 \\
Sweden, 1991 & 6.4 & 3.6 & 2.8 \\
US (S\&L), 1984 & 3.2 & 2.4 & 0.8 \\
\hline \hline
\end{tabular}

Sources: Frydl (1999) and sources cited therein and Vale (2006).

${ }^{1}$ In Norges Bank (2006) it is argued that the Norwegian government actually made a small profit on the banking resolution.

In what follows, we argue that this nearly universal focus on providing opaque calculations of bailout costs is both misguided and incomplete. It is misguided because there are no widely agreed upon guidelines to calculate these estimates. It is incomplete because the fiscal consequences of banking crises reach far beyond the more immediate bailout costs. These consequences mainly result from the significant adverse impact that the crisis has on government 
revenues (in nearly all cases) and the fact that in several episodes the fiscal policy reaction to the crisis has also involved substantial fiscal stimulus packages.

\section{Growth in the Aftermath of Crises}

The fact that most banking crises, especially systemic ones, are associated with economic downturns is well established in the empirical literature and we offer no new compelling evidence on that score. ${ }^{34}$ Reinhart and Rogoff (2008b) recently summarized the evolution of output before, during, and after all the banking crises (systemic or not) in post-WWII. Figure 7 shows the advanced economies as a group, as well as the "big five" (Japan, Nordics and Spain), while Figure $7 \mathrm{~b}$ augments this analysis with a comparable summary for the post-war banking crises in emerging markets. As before, time $t$ denotes the year of the crisis. It is interesting to note that the figures show a steeper decline but a somewhat faster comeback in growth for emerging markets than in the advanced economies. ${ }^{35}$ It is beyond the scope of this paper to ascertain the longer run growth consequences of banking crises, but we wish to note this postcrises pattern because growth (important in its own right) has nontrivial implications for fiscal balances, government debts, and the broader cost and consequences of any financial crisis.

\footnotetext{
${ }^{34}$ See, for instance, Frydl (1999), and Kaminsky and Reinhart (1999), and especially Rajan, Detragiache and Dell'Ariccia (2008), who examine the output consequences of the credit channel following banking crises using micro data. We note that the cases of output collapses studied in Barro and Ursua (2008) virtually all are associated with banking crises.

${ }^{35}$ It is important to note that the v-shaped pattern of recovery is importantly influenced by the sharp comebacks of the Asian economies from the severe 1997-1998 crisis. Excluding these countries considerably worsens the average performance two and three years after the banking crisis, making the pattern look more u-shaped.
} 
Figure 7a

\section{Real GDP Growth per Capita and Banking Crises (PPP 6asis)}

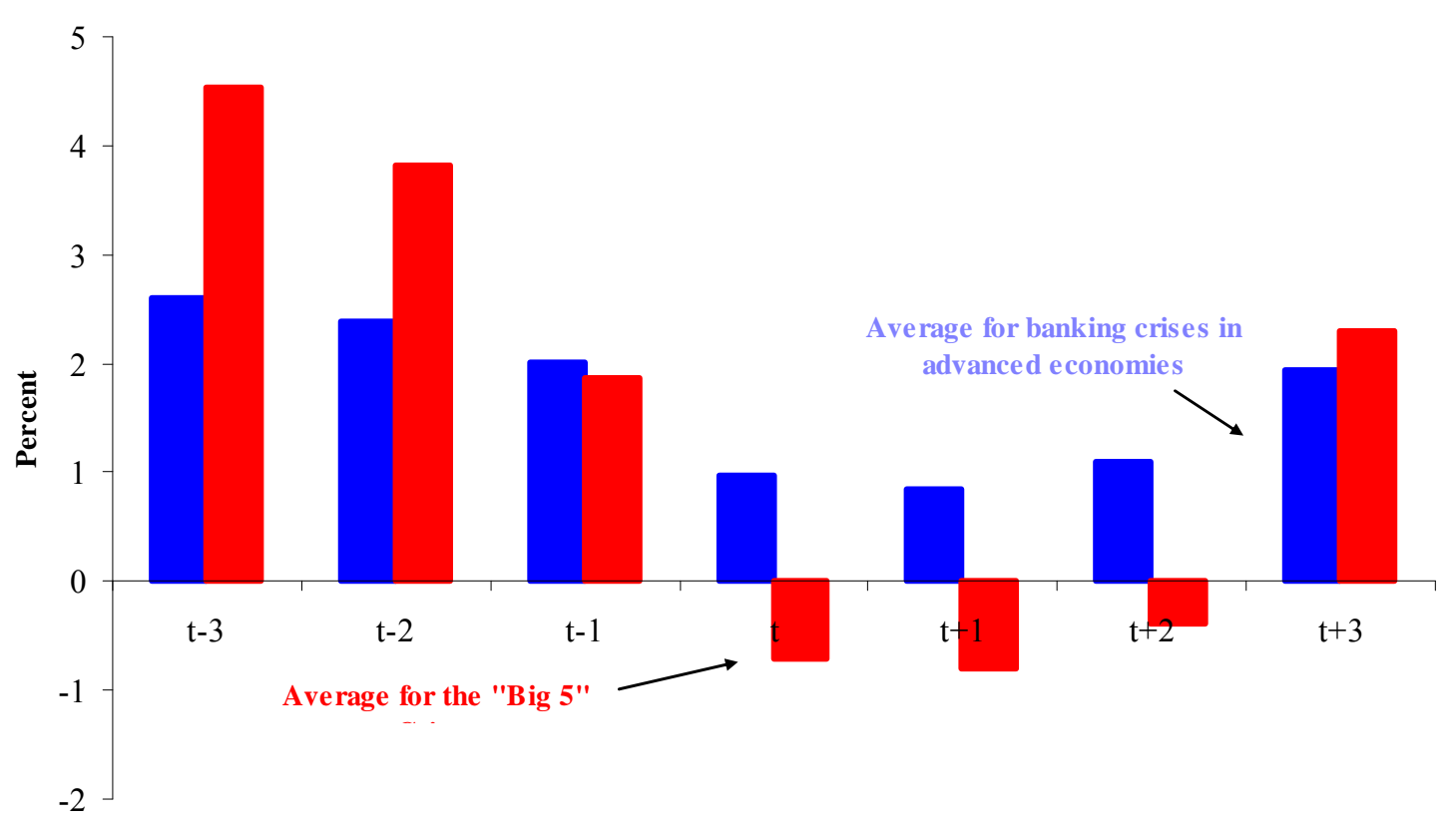

Sources: Maddison (2003), Total Economy Database (2008), IMF World Economic Outlook (2008), and author's calculations.

Notes: Banking crisis episodes are listed in Appendix II. 
Figure $7 \mathrm{~b}$

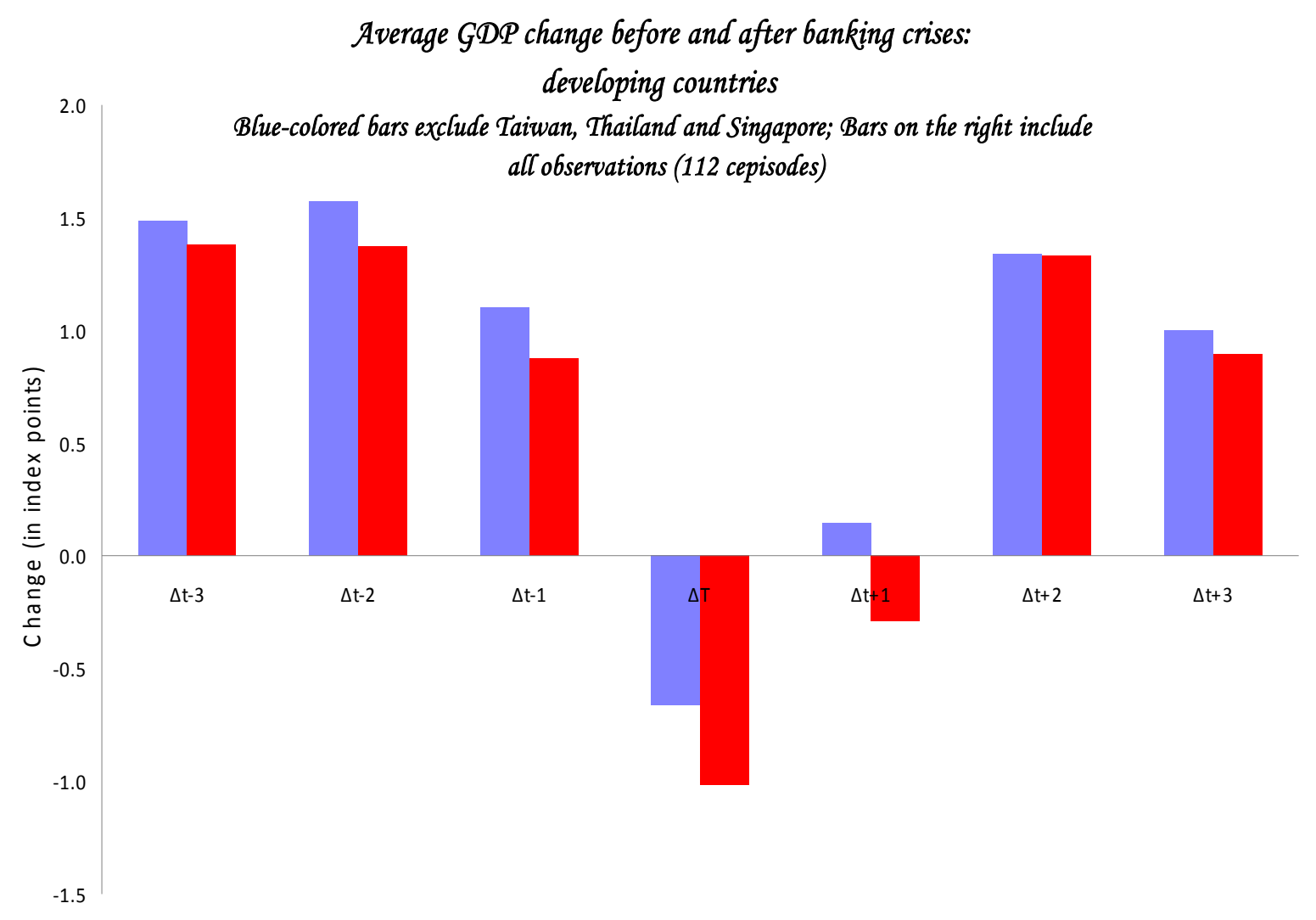

Sources: Maddison (2004), Total Economy Database (2008), IMF World Economic Outlook (2008), and author's calculations.

Notes: Banking Crisis episodes are listed in Appendix II. 


\section{Beyond Bailout Costs: The Impact Of The Crisis On Revenues And Debt}

Since WWII the most common policy response to a systemic banking crisis (in both emerging and advanced economies) has been to engineer (with varying degrees of success) a bailout of the banking sector, whether through purchases of bad assets, directed mergers of bad banks with relatively sound institutions, direct government takeovers, or some combination of these. Such actions have had in many cases major fiscal consequences, typically early on in the crisis. However, as noted earlier, banking crises are protracted affairs with lingering consequences in asset markets — notably real estate prices and the real economy. As such it is not surprising that government revenues are adversely and significantly impacted by the crisis.

As noted, several studies have traced out the adverse impacts of banking crises on economic activity; what these studies have left unexplored is the direct consequences of the recession on government finances_-specifically, tax revenues. Figure 8a plots the average pattern in annual real revenue growth three years before, during, and three years after banking crises for a total of 86 banking crises during 1800-1944 for which we have complete revenue data. $^{36}$

The comparable exercise is shown for all 138 post-WWII banking crises in Figure $8 \mathrm{~b}$. The patterns for the pre- and post-war samples are not identical but strikingly similar. Annual revenue growth is robust in the years leading up to the banking crisis; growth weakens significantly the year of the crisis and subsequently posts declines in the years immediately following the onset of the crisis. For the pre-war episodes revenues decline, on average for two years, while for the post-war the revenue slump extends to the third year.

\footnotetext{
${ }^{36}$ Revenues (from Mitchell, 2003a, b, and c ) are deflated by consumer price indices; the numerous sources for these data are given on a country-by-country and period-by-period basis in the data appendix to Reinhart and Rogoff (2008a).
} 
Figure 8a (all countries)

Real Government Revenue and Banking Crises, 1800-1940

(annual percent changes)

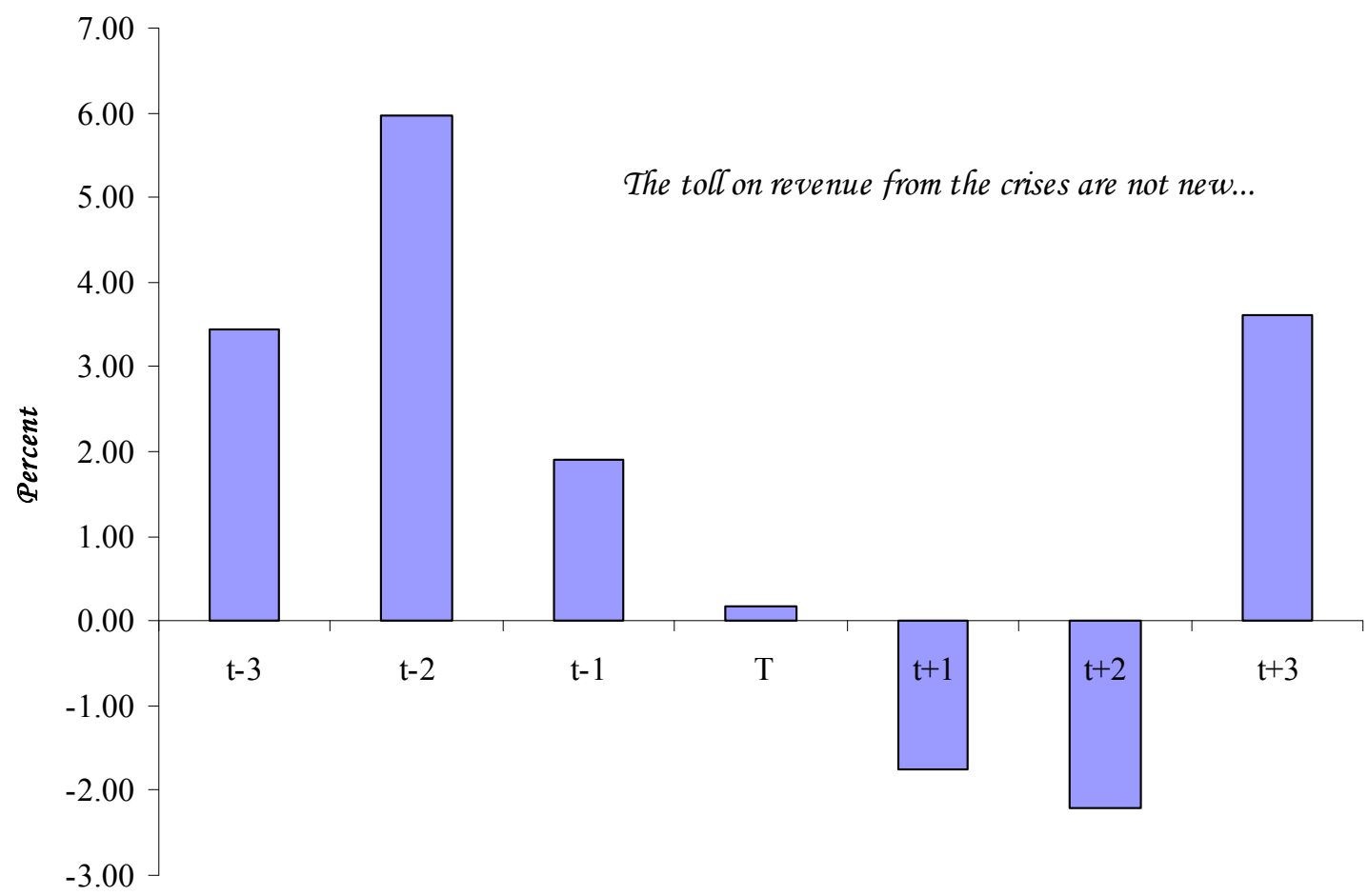

Sources: Revenues are from Mitchell (2003a, b, ). For the numerous country-specific sources of prices see Reinhart and Rogoff (2008a).

Notes: Central government revenues deflated by consumer prices. There are a total of 86 banking crisis episodes during 1800-1940 for which we have revenue data. 
Figure 8b (all countries)

\section{Real Government Reveues and Banking Crises \\ (annual percent changes)}

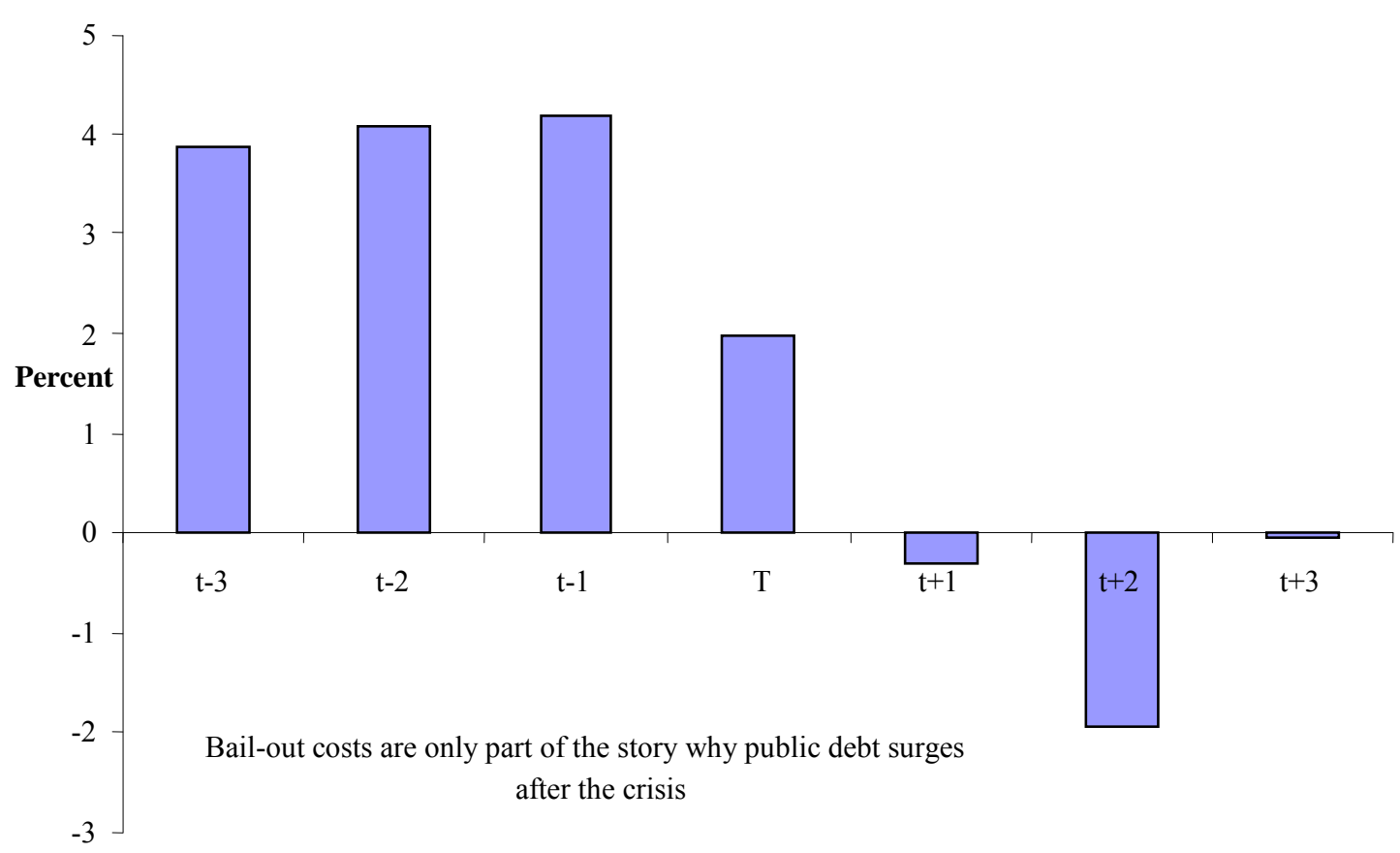

Sources: Revenues are taken from Mitchell (2003a, b). For the numerous country-specific sources of prices see Reinhart and Rogoff (2008a).

Notes: Central government revenues deflated by consumer prices. There are a total of 138 banking crises during 1945-2008 for which we have revenue data.

\section{Parallels in Revenue Losses between Emerging Markets and Developed Economies}

Again, the parallels between developed countries and emerging markets is striking. Figure $8 \mathrm{c}$ shows the revenue declines surrounding banking crises for the advanced countries across the entire sample, with the "big five" post-war crises also listed separately. Revenue growth resumes (from a lower base) starting in the third year after the crisis. Advanced economies exhibit a strong inclination to resort to stimulus measures to cushion economic activity, seen most spectacularly in the aggressive use of infrastructure spending in Japan during the 1990s. Emerging markets are far less well poised to engage in countercyclical fiscal policy. 
Nevertheless, the effect of the crisis on the trajectory of taxes is broadly similar. Figure $8 \mathrm{~d}$ gives revenue declines around banking crises for emerging markets for the entire sample. The average revenue drop is actually quite similar to the "big five," although the recovery is faster-in line with a more swift recovery in growth, as discussed in the preceding section.

Figure 8c

\section{Real Government Revenue and Banking Crises, Advanced Economies, 1815-2007 (annual percent changes)}

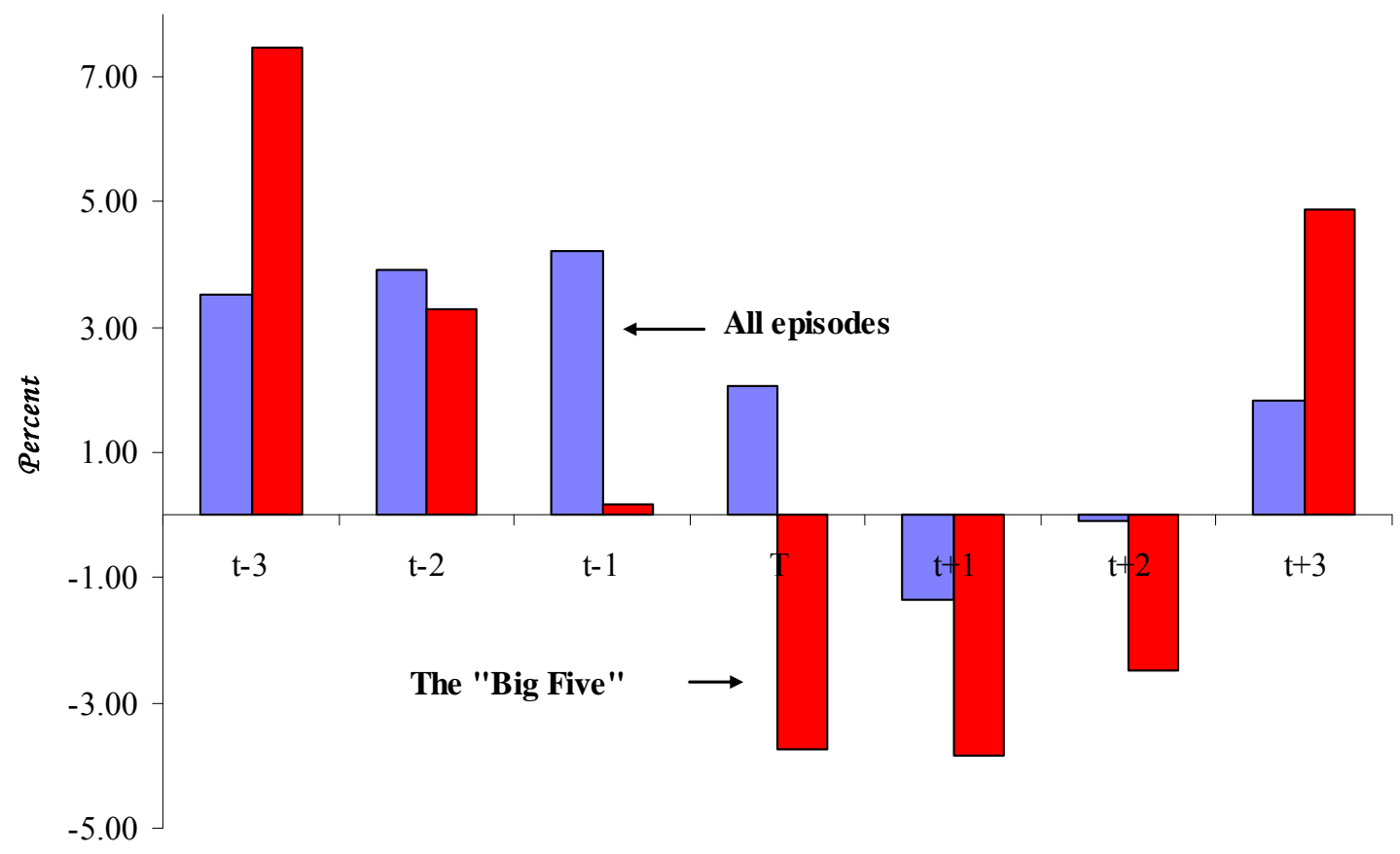

Sources: Revenues are taken from Mitchell (2003a, b, ). For the numerous country-specific sources of prices see Reinhart and Rogoff (2008a).

Notes: Central government revenues deflated by consumer prices. 
Figure 8d

\section{Real Government Revenue and Banking Crises, Emerging Markets, 1873-2007 \\ (annual percent changes)}

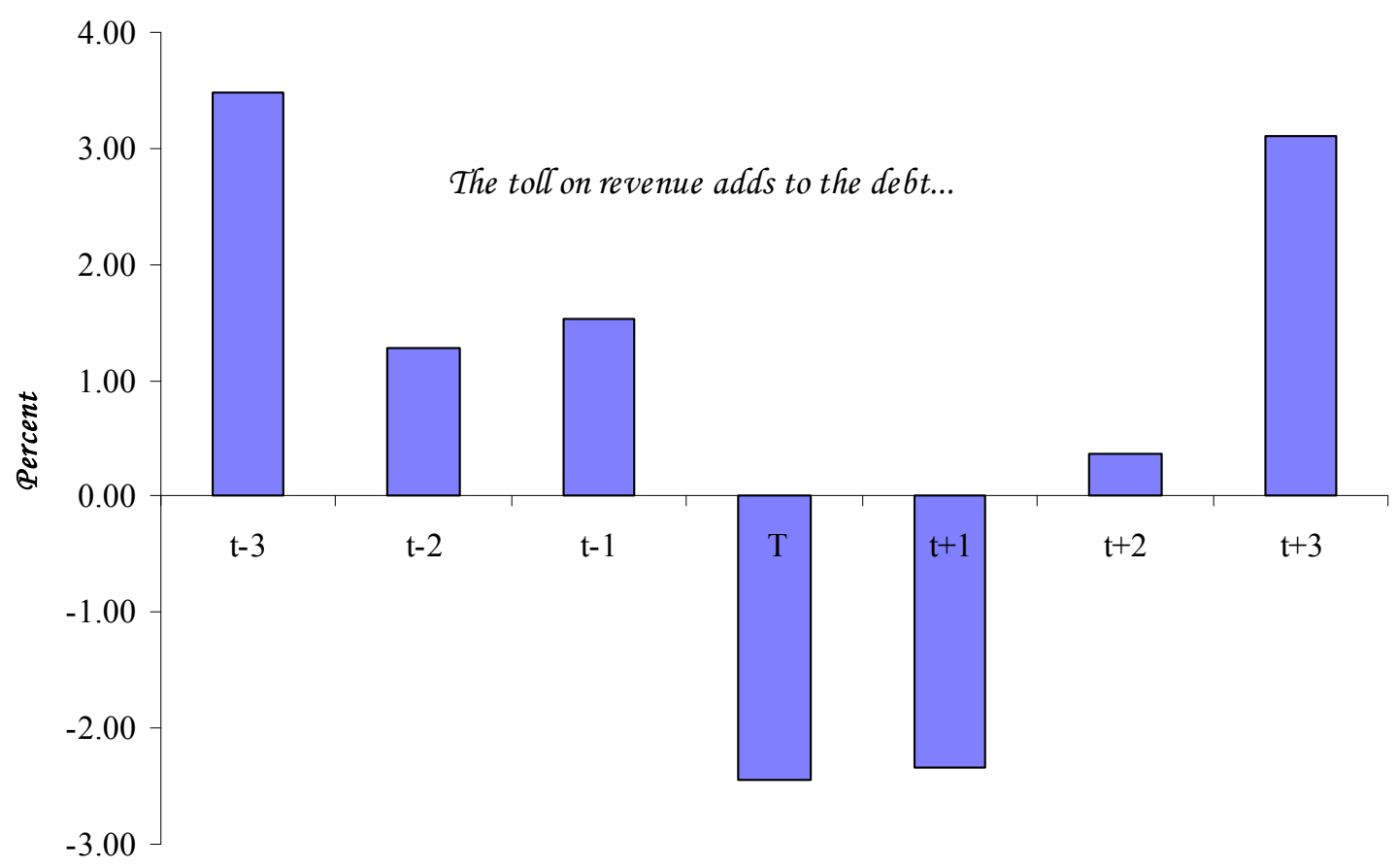

Sources: Revenues are from Mitchell (2003a, b). For the numerous country-specific sources of prices see Reinhart and Rogoff (2008a).

Notes: Central government revenues deflated by consumer prices.

\section{Government debt buildup in the aftermath of banking crises}

To get a rough approximation of the impact of a crisis on government finances, we use the historical central government debt data compiled in Reinhart and Rogoff (2008c). It is important to note that this is a partial picture, since the general (not just central government) is affected by the crisis. Also, there is typically during these episodes a marked expansion in government-guaranteed debt, which does not show up in the central government figures. 
With these caveats in mind, Figure 9 presents a summary of the evolution of debt in the aftermath of some of the major post-war crises in both advanced and emerging markets.

Figure 9

\section{Cumulative increase in public debt in the three years following the banking crisis}

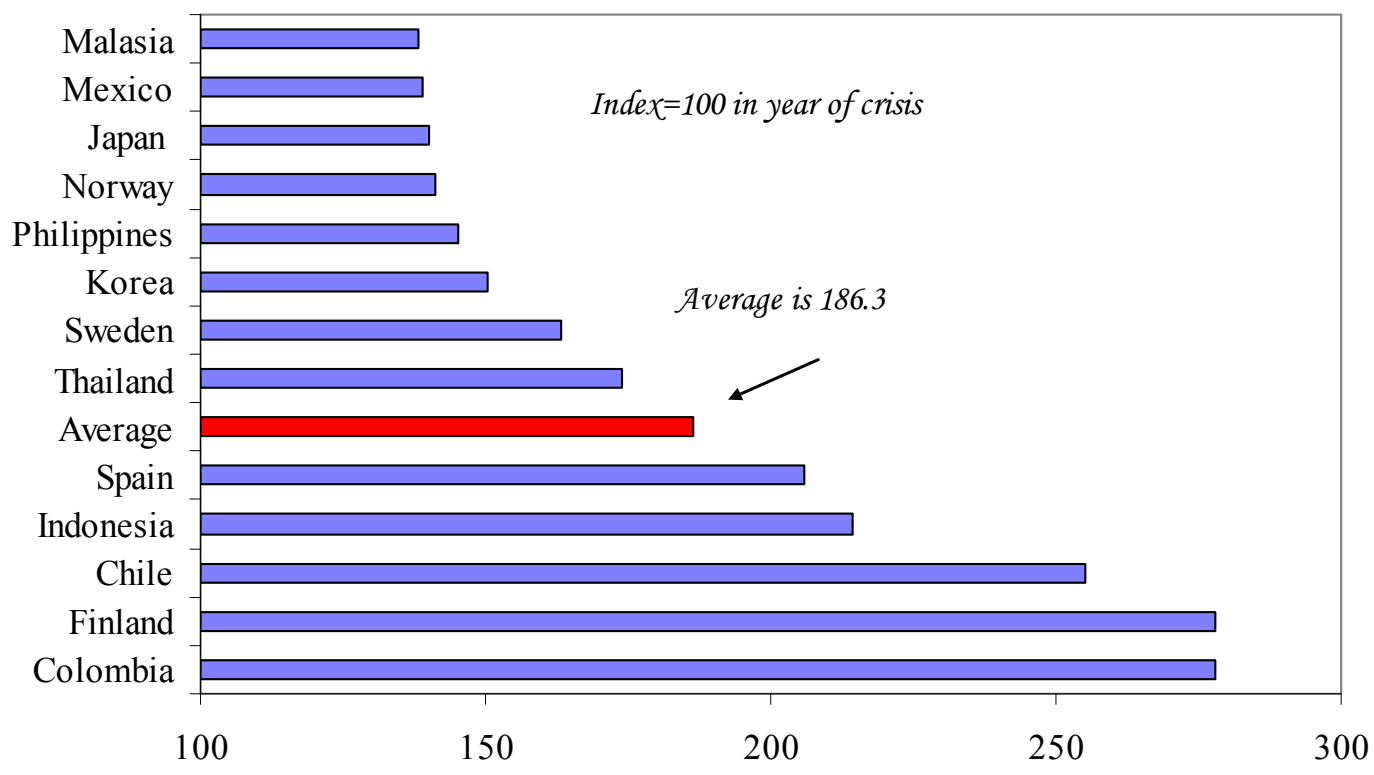

Source: Reinhart and Rogoff (2008c).

Not surprisingly, taken together, the bailout of the banking sector, the shortfall in revenue, and the fiscal stimulus packages that have accompanied some of these crises imply widening fiscal deficits adding to the existing stock of government debt. What is perhaps surprising is how dramatic the rise in debt is. If the stock of debt is indexed to equal 100 at the time of the crisis (T), the average experience is one in which the real stock of debt rises to 186 three years after the crisis. That is to say, the real stock of debt nearly doubles. ${ }^{37}$ Such increases in government indebtedness are evident in emerging and advanced economies alike,

\footnotetext{
${ }^{37}$ Indeed, there are some important cases such as Japan where the accelerated debt build-up goes on for over a decade, so the three-year cutoff grossly understates the longer term consequences.
} 
and extremely high in both. Arguably, the true legacy of banking crises is higher public indebtedness - far over and beyond the direct headline costs of big bailout packages. ${ }^{38}$

(Obviously, as we noted earlier, the rise in public debt depends on a whole range of political and economic factors, including the effectiveness of the policy response and the severity of the initial real economic shock that produced the crisis. Nevertheless, the universality of the large debt rise is stunning.)

\section{Concluding Remarks}

Countries may "graduate" from serial default on sovereign debt and recurrent episodes of very high inflation, as the cases of France, Austria, Spain and others illustrate. History tells us, however, that graduation from recurrent banking and financial crises is much more elusive. And it should not have taken the 2007-2009 financial crisis to remind us. Out of the 66 countries in our sample, only Portugal, Austria, the Netherlands and Belgium had managed to escape from banking crises from 1945-2007. During 2008, however, even three of these four countries were among those engaged in massive bailouts as the current global financial crisis evolves.

Indeed, the wave of financial crises that began with the onset of the subprime crisis in the United States in 2007 has dispelled any prior notion among academics, market participants, or policymakers that acute financial crises are either a thing of the past or relegated to the "volatile" emerging markets. The "this time is different syndrome" has been alive and well in the United States, where it first took the form of a widespread belief that sharp productivity gains stemming from the information technology industry justified price-earning ratios in the equity market that

\footnotetext{
${ }^{38}$ We note that Figure 9 gives percentage change in debt, rather than debt to GDP, in order not to distort numbers by the large falls in GDP that sometimes accompany crises. However, the same basic message comes across looking at debt to GDP instead. Note that the calculations are based on total central government debt.
} 
far exceeded any historical norm. ${ }^{39}$ That delusion ended with the burst of the IT bubble in 2001. But the excesses quickly reemerged, morphing into a different shape in a different market. The securitization of subprime mortgages combined with a heavy appetite for these instruments from countries like Germany, Japan, and major emerging markets like China fueled perceptions that housing prices would continue to climb forever. "This time it was different" because there were new markets, new instruments, and new lenders. In particular, financial engineering was thought to have tamed risk by better tailoring exposures to investors' appetites. Derivatives contracts, meanwhile, offered all manner of hedging opportunities. We now know how that popular delusion ended.

Historical experience already shows that rich countries are not as "special" as some cheerleaders had been arguing, both when it comes to managing capital inflows and especially when it comes to banking crises. This paper has used an extensive new dataset that includes data on housing prices in some key emerging markets as well as revenue and domestic debt data that dates back almost a century for most countries and more for many. Surprisingly, not only is the frequency and duration of banking crises similar across developed countries and middle-income countries, so too are quantitative measures of both the run-up and the fall-out. Notably, the duration of real housing price declines following financial crises in both groups are often four years or more, while the magnitudes of the crash are comparable. One striking finding is the huge surge in debt most countries experience in the wake of a financial crisis, with real central government debt typically increasing by about 86 percent on average (in real terms) during the three years following the crisis.

\footnotetext{
${ }^{39}$ An important question is how rare banking crises, through sudden changes in market liquidity, might amplify the effects on asset prices analyzed by Barro (2009).
} 


\section{References}

Agénor, Pierre-Richard, C. John McDermott, and Eswar Prasad, "Macroeconomic Fluctuations in Developing Countries: Some Stylized Facts," World Bank Economic Review, Vol. 14, May 2000, 251-285.

Barro, Robert, "Rare Disasters, Asset Prices and Welfare Costs," forthcoming American Economic Review, Volume 99, No. 1 (March 2009).

Barro, Robert J. and José Ursúa, “Macroeconomic Crises Since 1870,” NBER Working Paper 13940, April 2008.

Bernanke, Ben, S. and Harold James, in Ben S. Bernanke, "The Gold Standard, Deflation, and Financial Crisis: An International Comparison," Essays on the Great Depression, Princeton: Princeton University Press, 2000.

Bernanke, Ben S. and James, Harold, "The Gold Standard, Deflation, and Financial Crisis in the Great Depression: An International Comparison,” NBER Working Paper No. W3488, October 1990.

Bordo, Michael and Barry Eichengreen, 1999, "Is Our Current International Economic Environment Unusually Crisis Prone?" manuscript, Department of Economics, University of California, Berkeley, August.

Bordo, Michael, Barry Eichengreen, Daniela Klingebiel, and Maria Soledad Martínez-Pería, "Is the Crisis Problem Growing More Severe?” Economic Policy 16, April 2001, 51-82.

Bordo, Michael, and Olivier Jeanne, "Boom-Busts in Asset Prices, Economic Instability, and Monetary Policy,” NBER Working Paper 8966, June 2002.

Bordo, Michael, and Christopher Meissner (2006). "The Role of Foreign Currency Debt in Financial Crises: 1880-1913 vs 1972-1997” Journal of Banking and Finance.

Bordo, Michael, Christopher Meissner and Angela Redish, "How Original Sin Was Overcome: The Evolution of External Debt Denominated in Domestic Currencies in the United States and the British Dominions," in Barry Eichengreen and Ricardo Hausmann (eds), Other People's Money, Chicago: University of Chicago Press, 2004.

Bordo, Michael, and Antu Panini Murshid, “Are Financial Crises Becoming More Contagious?" in Stijn Claessens and Kristin Forbes, (eds.), International Financial Contagion, Kluwer Academic Press, 2001, 367-403.

Calomiris, Charles and Gary Gorton, “The Origins of Banking Panics: Models, Facts, and Bank Regulation," in R. Glenn Hubbard, ed., Financial Markets and Financial Crises, Chicago: University of Chicago press for the NBER, 1991. 
Cameron, Rondo E., Banking in the Early Stages of Industrialization: A Study in Comparative Economic History, New York: Oxford University Press, 1967

Camprubí Alcázar, Carlos, Historia de los Bancos en el Peru, 1860--1879, Lima, Peru, 1957.

Caprio, Gerald, Jr. and Klingebiel, Daniela, "Episodes of Systemic and Borderline Financial Crises," http://go.worldbank.org/5DYGICS7B0 (Dataset 1), January 2003.

Caprio, Gerald, Jr. and Klingebiel, Daniela, "Bank Insolvency: Bad Luck, Bad Policy, or Bad Banking?" in Boris Pleskovic and Joseph Stiglitz (eds.), Annual World Bank Conference on Development Economics, Washington, DC: The World Bank, 1996, 79-104.

Caprio, Gerard and Daniela Klingebiel, Luc Laeven and Guillermo Noguera, "Banking Crisis Database," In Patrick Honohan and Luc Laeven (eds.), Systemic Financial Crises, Cambridge: Cambridge University Press, 2005.

Ceron, Jose, and Javier Suarez, "Hot and Cold Housing Markets: International Evidence," CEMFI Working Paper 0603, January 2006.

Cheng, Linsun, Banking in Modern China: Entrepreneurs, Professional Managers, and the Development of Chinese Banks, 1897-1937, Cambridge: Cambridge University Press, 2003.

Conant, Charles A., A History of Modern Banks of Issue, $5^{\text {th }}$ edition, New York: G.D. Putnam's Sons, 1915.

Conant, Charles A. and Marcus Nadler, in Charles A. Conant, A History of Modern Banks of Issue, New York: G.D. Putnam's Sons, 1927.

Correlates of War, http://correlatesofwar.org/

Della Paolera, Gerardo and Alan M. Taylor, Straining at the Anchor: The Argentine Currency Board and the Search for Macroeconomic Stability, 1880-1935, Chicago: University of Chicago Press, 2001.

Della Paolera, Gerardo and Alan M. Taylor, "Internal Versus External Convertibility and Emerging-Market Crises: Lessons from Argentine History," Explorations in Economic History 39 (October 2002): 357-89.

Della Paolera, Gerardo and Alan M. Taylor, "Internal Versus External Convertibility and Developing-Country Financial Crises: Lessons From The Argentine Bank Bailout of the 1930s,” NBER Working Paper No. 7386 (October 1999).

Dell'Ariccia, Giovanni \& Detragiache, Enrica \& Rajan, Raghuram, 2008. "The Real Effect of Banking Crises," Journal of Financial Intermediation, Elsevier, vol. 17(1), pages 89-112, January. 
Demirgüç-Kunt, Asli and Enrica Detragiache, "The Determinants of Banking Crises in Developing and Developed Countries," IMF Staff Papers Vol. 45 (1998), 81-109.

Demirgüç-Kunt, Asli and Enrica Detragiache, "Financial Liberalization and Financial Fragility," in Boris Pleskovic and Joseph Stiglitz (eds.) Annual World Bank Conference on Development Economics 1998, Washington, DC: World Bank, 1999.

Drees, Burkhard, and Ceyla Pazarbasioglu, The Nordic Banking Crisis: Pitfalls in Financial Liberalization, IMF Occasional Paper 161, Washington DC: International Monetary Fund, 1998.

Flath, David, The Japanese Economy, $2^{\text {nd }}$ ed., Oxford: University Press, 2005.

Frydl, Edward J., "The Length and Cost of Banking Crises,” IMF Working Paper WP/99/30, March 1999.

Gerdrup, Karsten R., "Three Episodes of Financial Fragility in Norway since the 1890s," BIS Working Paper No. 142, October 2003.

Gorton, Gary, "Banking Panics and Business Cycles," Oxford Economic Papers, 1988, 40, pp. $751-81$.

International Monetary Fund, Global Financial Stability Reports, various issues.

International Monetary Fund, International Financial Statistics, various issues.

International Monetary Fund, World Economic Outlook, various issues.

Jácome, Luis, "Central Bank Involvement in Banking Crises in Latin America," IMF Working Paper WP/08/135, May 2008.

Jeanne, Olivier and Alexandra Guscina, 2006, "Government Debt in Emerging Market Countries: A New Data Set," IMF Working Paper No. 6/98, April.

Johnson, H. Clark, Gold, France, and the Great Depression: 1919-1935, Yale University Press, New Haven: 1998.

Jonung, L. and T. Hagberg, “How costly was the crisis?” Työväen Akatemia, Kauniainen; September 2002.

Kaminsky, Graciela L. and Carmen M. Reinhart, "The Twin Crises: The Causes of Banking and Balance of Payments Problems," American Economic Review, Vol. 89 No. 3, June 1999, 473-500. 
Kaminsky, Graciela L. and Carmen M. Reinhart, and Carlo Vegh, "When It Rains It Pours: Procyclical Capital Flows and Macroeconomic Policies," NBER Macro Annual 2004 (Kenneth Roggoff and Mark Gertler, editors), MIT Press, 2005.

Kindleberger, Charles P., Manias, Panics and Crashes: A History of Financial Crises (New York: Basic Books, 1989).

Kryzanowski, Lawrence and Gordon S. Roberts, "Perspectives on Canadian Bank Insolvency During the 1930s," Journal of Money, Credit \& Banking, Vol. 31, No. 1, February 1999.

Lindert, Peter H. and Peter J. Morton, "How Sovereign Debt Has Worked," in Jeffrey Sachs, ed., Developing Country Debt and Economic Performance, Vol. 1, University of Chicago Press, 1989, 39-106.

MacDonald, James, A Free Nation Deep in Debt: The Financial Roots of Democracy (New York: Farrar, Straus, and Giroux, 2003).

Maddison, Angus, Historical Statistics for the World Economy: 1-2003 AD. (Paris: OECD, 2004). http://www.ggdc.net/maddison/

McElderry, Andrea Lee, Shanghai Old-Style Banks 1800-1935: A Traditional Institution in a Changing Society, Ann Arbor: Center for Chinese Studies, University of Michigan, 1976.

Mendoza, Enrique G. and Marco Terrones, "An Anatomy of Credit Booms: Evidence from the Macro Aggregates and Micro Data," NBER Working Paper 14049, May 2008.

Mitchell, Brian R., International Historical Statistics: Africa, Asia, and Oceania, 1750-2000, London: Palgrave MacMillan, 2003a.

Mitchell, Brian R., International Historical Statistics: The Americas, 1750-2000, London: Palgrave MacMillan, 2003b.

Nakamura, Leonard I. and Carlos E.J.M. Zarazaga, "Banking and Finance in Argentina in the Period 1900-35," June 2001, FRB Philadelphia Working Paper No. 01-7.

Neal, Larry, and Marc Weidenmier, "Crises in the Global Economy from Tulips to Today: Contagion and Consequences," in Michael D. Bordo, Alan M. Taylor, and Jeffrey G. Williamson (eds.), Globalization in Historical Perspective, Chicago: University of Chicago Press for the NBER, 2003.

Neely, Christopher, "The Profitability of U.S. Intervention in the Foreign Exchange Markets," Journal of International Money and Finance Vol. 14, (1995), 823-844.

Noel, Maurer, The Power and the Money-The Mexican Financial System, 1876-1932, Stanford: Stanford University Press, 2002. 
Norges Bank, The Norwegian Banking Crisis, Occasional Paper No 33, Norges Bank, 2006.

Obstfeld, Maurice, and Alan M. Taylor, Global Capital Markets: Integration, Crisis, and Growth, Japan-U.S. Center Sanwa Monographs on International Financial Markets, Cambridge: Cambridge University Press, 2004.

Øksendal, Lars, "Re-Examining Norwegian Monetary Policy in the 1930s," manuscript, Department of Economics, Norwegian School of Economics and Business Administration, 2007.

Philippon, Thomas, "Why has the US Financial Sector Grown So Much? The Role of Corporate Finance," National Bureau of Economic Research Working Paper 13405, September 2007.

Purcell, John F. H., and Jeffrey A. Kaufman, The Risks of Sovereign Lending: Lessons from History, New York: Salomon Brothers, 1993.

Rajan, Raghuram, Enrica Detragiache and Giovanni Dell'Ariccia, "The Real Effect of Banking Crises," Journal of Financial Intermediation Vol. 17, 2008, 89-112.

Reinhart, Carmen M., "Default, Currency Crises, and Sovereign Credit Ratings," World Bank Economic Review, Vol. 16 No. 2, 2002, 151-170.

Reinhart, Carmen M., and Vincent R. Reinhart, "Capital Flow Bonanzas: An Encompassing View of the Past and Present," in Jeffrey Frankel and Francesco Giavazzi (eds.), NBER International Seminar in Macroeconomics 2008, Chicago: Chicago University Press for NBER, forthcoming.

Reinhart, Carmen M., Kenneth S. Rogoff, and Miguel A. Savastano, "Debt Intolerance," Brookings Papers on Economic Activity, Vol. 1, Spring 2003, 1-74.

Reinhart, Carmen M., and Kenneth S. Rogoff, "This Time Is Different: A Panoramic View of Eight Centuries of Financial Crises," NBER Working Paper 13882, March 2008a.

Reinhart, Carmen M., and Kenneth S. Rogoff, "Is the 2007 U.S. Subprime Crisis So Different? An International Historical Comparison," American Economic Review, Vol. 98 No. 2, May 2008b, 339-344.

Reinhart, Carmen M., and Kenneth S. Rogoff, "The Forgotten History of Domestic Debt," NBER Working Paper 13946, April 2008c.

Sanhueza, Gonzalo, "Chilean Banking Crisis of the 1980s: Solutions and Estimation of the Costs," Central Bank of Chile Working Paper 104, Santiago, Chile, 2001.

Shiller, Robert, Irrational Exuberance, Princeton, NJ: Princeton University Press, 2005. 
Shin, Inseok and Joon-Ho Hahm, 1998, “The Korean Crisis: Causes and Resolution,” Korea Development Institute, Working Paper, prepared for the KDI-EWC Conference on the Korean Crisis: Causes and Resolution, August 1998, Hawaii.

Sundararajan, Vasudevan, and Tomás Baliño, Banking Crises: Cases and Issues Washington DC: International Monetary Fund, 1991.

Suter, Christian, Debt Cycles in the World-Economy: Foreign Loans, Financial Crises, and Debt Settlements, 1820-1990, Boulder: Westview Press, 1992.

Sutton, Gregory D., "Explaining Changes in House Prices," BIS Quarterly Review (September 2002): 46-55.

Teichova, Alice, Ginette Kurgan-van Hentenryk, and Dieter Ziegler (eds), Banking, Trade and Industry: Europe, America and Asia from the thirteenth to the twentieth century, Cambridge University Press, 1997.

Temin, Peter, "The German Crisis of 1931: Evidence and Tradition," Cliometrica: Journal of Historical Economics and Econometric History 2(1), 2008, pp. 5-17.

Total Economy Database, http://www.conference-board.org/economics/database.cfm.

Vale, Bent, The Norwegian Banking Crisis, Occasional Paper No 33, Norges Bank, 2006.

Vogler R., "The Genesis of Swiss Banking Secrecy: Political and Economic Environment," Financial History Review 8(1), 2001, pp. 73-84.

Willis, Parker H., and B.H. Beckhart, eds., Foreign Banking Systems, (New York: Henry Holt and Company, Inc., 1929).

Young, Arthur Nichols, China's Nation-building Effort, 1927-1937: The Financial and Economic Record, Stanford: Stanford University, 1971. 


\section{Appendix I. Country sample, crisis definition and dates}

In this section, we list the countries in the core sample (Table A1), and describe the criteria used in this study to date banking crises.

With regard to banking crises, our analysis stresses events. The main reason for following this approach has to do with the lack of long time-series data that would allow us to date banking or financial crises quantitatively along the lines of inflation or currency crashes. For example, the relative price of bank stocks (or financial institutions relative to the market) would be a logical indicator to examine. However, this is problematic, particularly for the earlier part of our sample as well as for developing countries (where many domestic banks do not have publicly traded equity).

If the beginning of a banking crisis is marked by bank runs and withdrawals, then changes in bank deposits could be used to date the crises. This indicator would have certainly done well in dating the numerous banking panics of the 1800s. Often, however, the banking problems do not arise from the liability side, but from a protracted deterioration in asset quality, be it from a collapse in real estate prices or increased bankruptcies in the nonfinancial sector. In this case, a large increase in bankruptcies or nonperforming loans could be used to mark the onset of the crisis. Indicators of business failures and nonperforming loans are also usually available only sporadically, if at all; the latter are also made less informative by the banks' desire to hide their problems for as long as possible. 
Table A1. Countries, Regions, and World GDP

\begin{tabular}{|c|c|c|c|}
\hline \multirow{2}{*}{$\begin{array}{l}\text { Country (An asterisk } \\
\text { denotes no sovereign } \\
\text { default or rescheduling } \\
\text { history) }\end{array}$} & \multirow[t]{2}{*}{$\begin{array}{l}\text { Year of Independence } \\
\quad \text { if after } 1800\end{array}$} & \multicolumn{2}{|c|}{$\begin{array}{c}\text { Share of World Real GDP } \\
1990 \text { International Geary-Khamis US dollars }\end{array}$} \\
\hline & & 1913 & 1990 \\
\hline \multicolumn{4}{|l|}{ Africa } \\
\hline Algeria & 1962 & 0.23 & 0.27 \\
\hline Angola & 1975 & 0.00 & 0.03 \\
\hline Central Africa Republic & 1960 & 0.00 & 0.01 \\
\hline Côte D'Ivoire & 1960 & 0.00 & 0.06 \\
\hline Egypt & 1831 & 0.40 & 0.53 \\
\hline Kenya & 1963 & 0.00 & 0.10 \\
\hline Mauritius * & 1968 & 0.00 & 0.03 \\
\hline Morocco & 1956 & 0.13 & 0.24 \\
\hline Nigeria & 1960 & 0.00 & 0.40 \\
\hline South Africa & 1910 & 0.36 & 0.54 \\
\hline Tunisia & 1957 & 0.06 & 0.10 \\
\hline Zambia & 1964 & 0.00 & 0.02 \\
\hline Zimbabwe & 1965 & 0.00 & 0.05 \\
\hline \multicolumn{4}{|l|}{ Asia } \\
\hline China & & 8.80 & 7.70 \\
\hline \multicolumn{4}{|l|}{ Hong Kong * } \\
\hline India & 1947 & 7.47 & 4.05 \\
\hline Indonesia & 1949 & 1.65 & 1.66 \\
\hline Japan & & 2.62 & 8.57 \\
\hline Korea * & 1945 & 0.34 & 1.38 \\
\hline Malaysia * & 1957 & 0.10 & 0.33 \\
\hline Myanmar & 1948 & 0.31 & 0.11 \\
\hline Philippines & 1947 & 0.34 & 0.53 \\
\hline Singapore * & 1965 & 0.02 & 0.16 \\
\hline Taiwan * & 1949 & 0.09 & 0.74 \\
\hline Thailand * & & 0.27 & 0.94 \\
\hline \multicolumn{4}{|l|}{ Europe } \\
\hline Austria & & 0.86 & 0.48 \\
\hline Belgium * & 1830 & 1.18 & 0.63 \\
\hline Denmark * & & 0.43 & 0.35 \\
\hline Finland * & 1917 & 0.23 & 0.31 \\
\hline France & & 5.29 & 3.79 \\
\hline Germany & & 8.68 & 4.67 \\
\hline Greece & 1829 & 0.32 & 0.37 \\
\hline Hungary & 1918 & 0.60 & 0.25 \\
\hline Italy & & 3.49 & 3.42 \\
\hline Netherlands * & & 0.91 & 0.95 \\
\hline Norway * & 1905 & 0.22 & 0.29 \\
\hline Poland & 1918 & 1.70 & 0.72 \\
\hline Portugal & & 0.27 & 0.40 \\
\hline Romania & 1878 & 0.80 & 0.30 \\
\hline Russia & & 8.50 & 4.25 \\
\hline Spain & & 1.52 & 1.75 \\
\hline Sweden & & 0.64 & 0.56 \\
\hline Turkey & & 0.67 & 1.13 \\
\hline United Kingdom * & & 8.22 & 3.49 \\
\hline
\end{tabular}

Sources: Correlates of War (2007), Maddison (2004).

Notes: An asterisk denotes no sovereign external default or rescheduling history. 
Table A1 (concluded) Countries, Regions, and World GDP

\section{Year of Independence if after 1800}

\author{
Share of World Real GDP \\ 1990 International Geary-Khamis US dollars
}

$\begin{array}{lccc}\text { Latin America } & & 1913 & 1990 \\ \text { Argentina } & 1816 & 1.06 & 0.78 \\ \text { Bolivia } & 1825 & 0.00 & 0.05 \\ \text { Brazil } & 1822 & 0.70 & 2.74 \\ \text { Chile } & 1818 & 0.38 & 0.31 \\ \text { Colombia } & 1819 & 0.23 & 0.59 \\ \text { Costa Rica } & 1821 & 0.00 & 0.05 \\ \text { Dominican Republic } & 1845 & 0.00 & 0.06 \\ \text { Ecuador } & 1830 & 0.00 & 0.15 \\ \text { El Salvador } & 1821 & 0.00 & 0.04 \\ \text { Guatemala } & 1821 & 0.00 & 0.11 \\ \text { Honduras } & 1821 & 0.00 & 0.03 \\ \text { Mexico } & 1821 & 0.95 & 1.91 \\ \text { Nicaragua } & 1821 & 0.00 & 0.02 \\ \text { Panama } & 1903 & 0.00 & 0.04 \\ \text { Paraguay } & 1811 & 0.00 & 0.05 \\ \text { Peru } & 1821 & 0.16 & 0.24 \\ \text { Uruguay } & 1811 & 0.14 & 0.07 \\ \text { Venezuela } & 1830 & 0.12 & 0.59 \\ \text { North America } & & & \\ \text { Canada * } & 1867 & 1.28 & 1.94 \\ \text { United States * } & & 18.93 & 21.41 \\ \text { Oceania } & & & \\ \text { Australia * } & 1901 & 0.91 & 1.07 \\ \text { New Zealand * } & 1907 & 0.21 & 0.17 \\ & & \text { Total Sample-66 countries } & \\ & & 93.04 & 89.24\end{array}$

Sources: Correlates of War (2007), Maddison (2004). 
Given these data limitations, we mark a banking crisis by two types of events: (1) bank runs that lead to the closure, merging, or takeover by the public sector of one or more financial institutions (as in Venezuela in 1993 or Argentina in 2001); and (2) if there are no runs, the closure, merging, takeover, or large-scale government assistance of an important financial institution (or group of institutions) that marks the start of a string of similar outcomes for other financial institutions (as in Thailand 1996-97). We rely on existing studies of banking crises and on the financial press; according to these studies the fragility of the banking sector was widespread during these periods.

Many country-specific studies (such as Camprubi, 1957, for Peru; Cheng, 2003, McElderry, 1976, for China; and Noel, 2002, for Mexico) pick up banking crisis episodes not covered by the multicountry literature and contribute importantly to this chronology, but the main sources for cross-country dating of crises are as follows: For post-1970, the comprehensive and well-known study by Caprio and Klingebiel — which the authors updated through 2003 - is authoritative, especially when it comes to classifying banking crises into systemic or more benign categories; Kaminsky and Reinhart (1999), and Jácome (2008) for Latin America round out the sources. For pre-World War II, Kindleberger (1989), Bordo et al. (2001), and Willis and Beckhart (1929) provide multicountry coverage on banking crises.

We relegate a summary discussion of the limitations of this event-based dating approach to Table A2, while the years in which the banking crises began are listed in Table A3unfortunately, for many of the early episodes it is difficult to ascertain how long the crisis lasted. 
Table A2. Defining Banking Crises by Events: A Summary

\begin{tabular}{|c|c|c|}
\hline Type of Crisis & Definition and/or Criteria & Comments \\
\hline $\begin{array}{l}\text { Banking crisis } \\
\text { Type I: } \\
\text { systemic/severe } \\
\text { Type II: } \\
\text { financial } \\
\text { distress/milder }\end{array}$ & $\begin{array}{l}\text { We mark a banking crisis by two types } \\
\text { of events: (1) bank runs that lead to the } \\
\text { closure, merging, or takeover by the } \\
\text { public sector of one or more financial } \\
\text { institutions; and (2) if there are no runs, } \\
\text { the closure, merging, takeover, or } \\
\text { large-scale government assistance of an } \\
\text { important financial institution (or group } \\
\text { of institutions) that marks the start of a } \\
\text { string of similar outcomes for other } \\
\text { financial institutions. }\end{array}$ & $\begin{array}{l}\text { This approach to dating the beginning of a } \\
\text { banking crisis is not without drawbacks. It } \\
\text { could date a crisis too late, because the } \\
\text { financial problems usually begin well before } \\
\text { a bank is finally closed or merged; it could } \\
\text { also date a crisis too early, because the worst } \\
\text { part of a crisis may come later. Unlike the } \\
\text { external debt crises (see below), which have } \\
\text { well-defined closure dates, it is often difficult } \\
\text { or impossible to accurately pinpoint the year } \\
\text { in which a crisis ended. }\end{array}$ \\
\hline
\end{tabular}


Table A3. Banking Crises Dates and Capital Mobility: 1800-2007

\begin{tabular}{|c|c|c|c|c|c|}
\hline \multicolumn{2}{|c|}{ High-Income } & \multicolumn{2}{|c|}{ Middle Income } & \multicolumn{2}{|c|}{ Low Income } \\
\hline Country (ies) & BeginningYear & Country (ies) & BeginningYear & Country (ies) & BeginningYear \\
\hline \multicolumn{6}{|c|}{ Capital Mobility: Low-Moderate, 1800-1879 } \\
\hline France & 1802 & & & & \\
\hline France & 1805 & & & & \\
\hline UK & 1810 & & & & \\
\hline UK & 1815 & & & & \\
\hline Denmark & 1813 & & & & \\
\hline US & 1818 & & & & \\
\hline UK, US & 1825 & & & & \\
\hline US & 1836 & & & & \\
\hline Canada, UK & 1837 & & & & \\
\hline UK & 1847 & & & & \\
\hline Belgium & 1848 & & & & \\
\hline UK, US & 1857 & & & India & 1863 \\
\hline Italy, UK & 1866 & & & & \\
\hline Austria, US & 1873 & Peru & 1873 & & \\
\hline & & South Africa & 1877 & & \\
\hline \multicolumn{6}{|c|}{ Capital Mobility: High, 1880-1914 } \\
\hline Germany & 1880 & & & & \\
\hline France & 1882 & Mexico & 1883 & & \\
\hline US & 1884 & & & & \\
\hline Denmark & 1885 & & & & \\
\hline Italy & 1887 & & & & \\
\hline France & 1889 & & & & \\
\hline Portugal, UK, & 1890 & Argentina* & 1890 & & \\
\hline & & $\begin{array}{l}\text { Brazil, Chile, } \\
\text { South Africa }\end{array}$ & & & \\
\hline Germany, & 1891 & & & & \\
\hline Italy, Portugal & & & & & \\
\hline Australia & 1893 & & & & \\
\hline $\begin{array}{l}\text { Netherlands, } \\
\text { Sweden }\end{array}$ & 1897 & & & & \\
\hline Norway & 1898 & Chile & 1899 & & \\
\hline Finland & 1900 & Brazil & 1900 & & \\
\hline Germany, & 1901 & & & & \\
\hline Japan & & & & & \\
\hline Denmark, & 1907 & Mexico & 1907 & & \\
\hline France, Italy, & & & & & \\
\hline Japan, & & & & & \\
\hline Sweden, US & & & & & \\
\hline \multirow{9}{*}{$\begin{array}{l}\text { Belgium, } \\
\text { France*, Italy, } \\
\text { Japan, } \\
\text { Netherlands, } \\
\text { Norway, }{ }^{*} \text { UK, } \\
\text { US }\end{array}$} & & Chile & 1908 & & \\
\hline & & Mexico & 1913 & India & 1913 \\
\hline & 1914 & Argentina*, & 1914 & & \\
\hline & & Brazil* & & & \\
\hline & & & & & \\
\hline & & & & & \\
\hline & & & & & \\
\hline & \multicolumn{3}{|c|}{ Capital Mobility: Low, 1915-1919 } & & \\
\hline & & Chile* & 1915 & & \\
\hline
\end{tabular}


Table A3. Banking Crises Dates and Capital Mobility: 1800-2007 (continued)

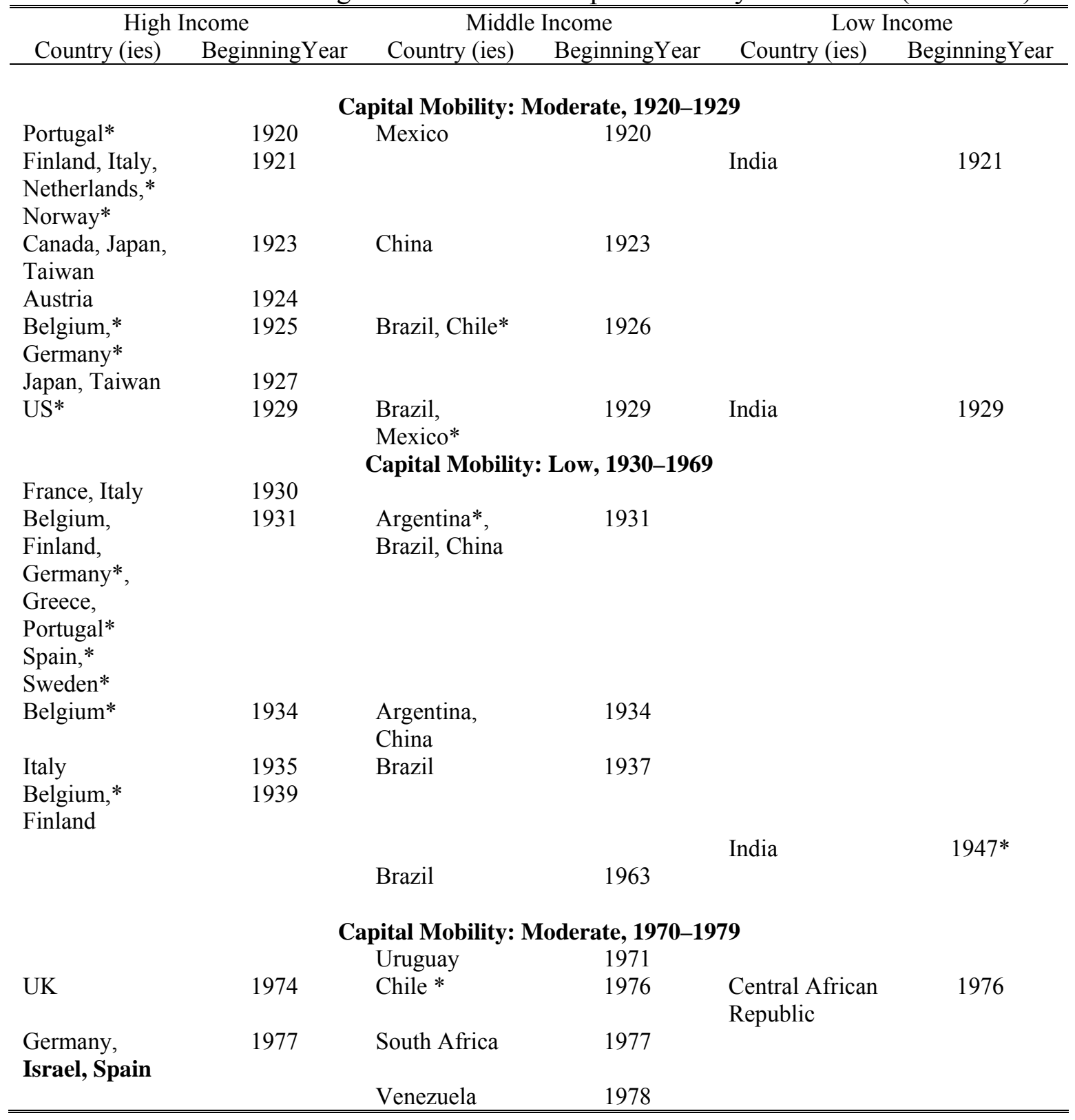


Table A3. Banking Crises Dates and Capital Mobility: 1800-2007 (continued)

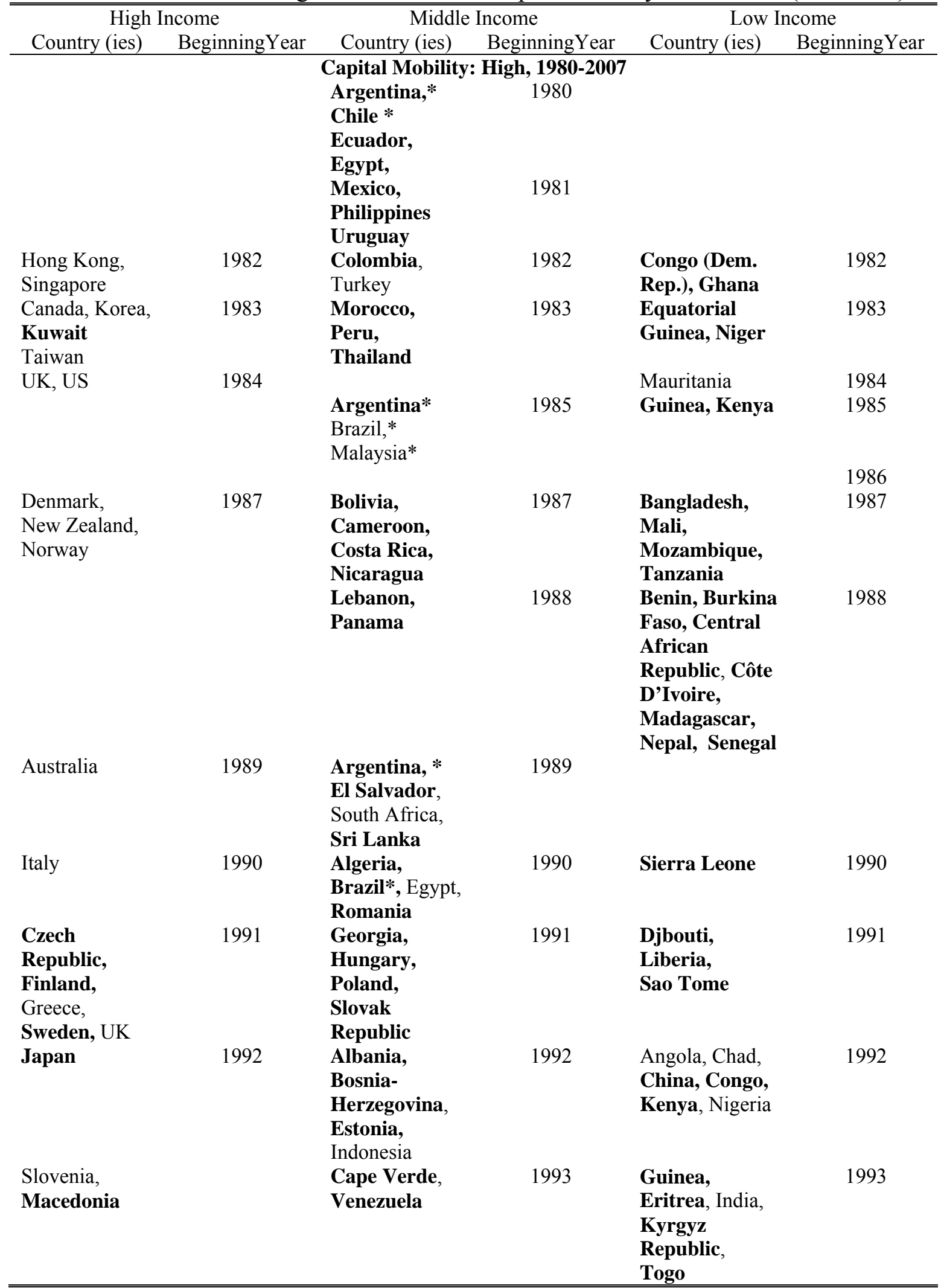


Table A3. Banking Crises Dates and Capital Mobility: 1800-2007 (continued)

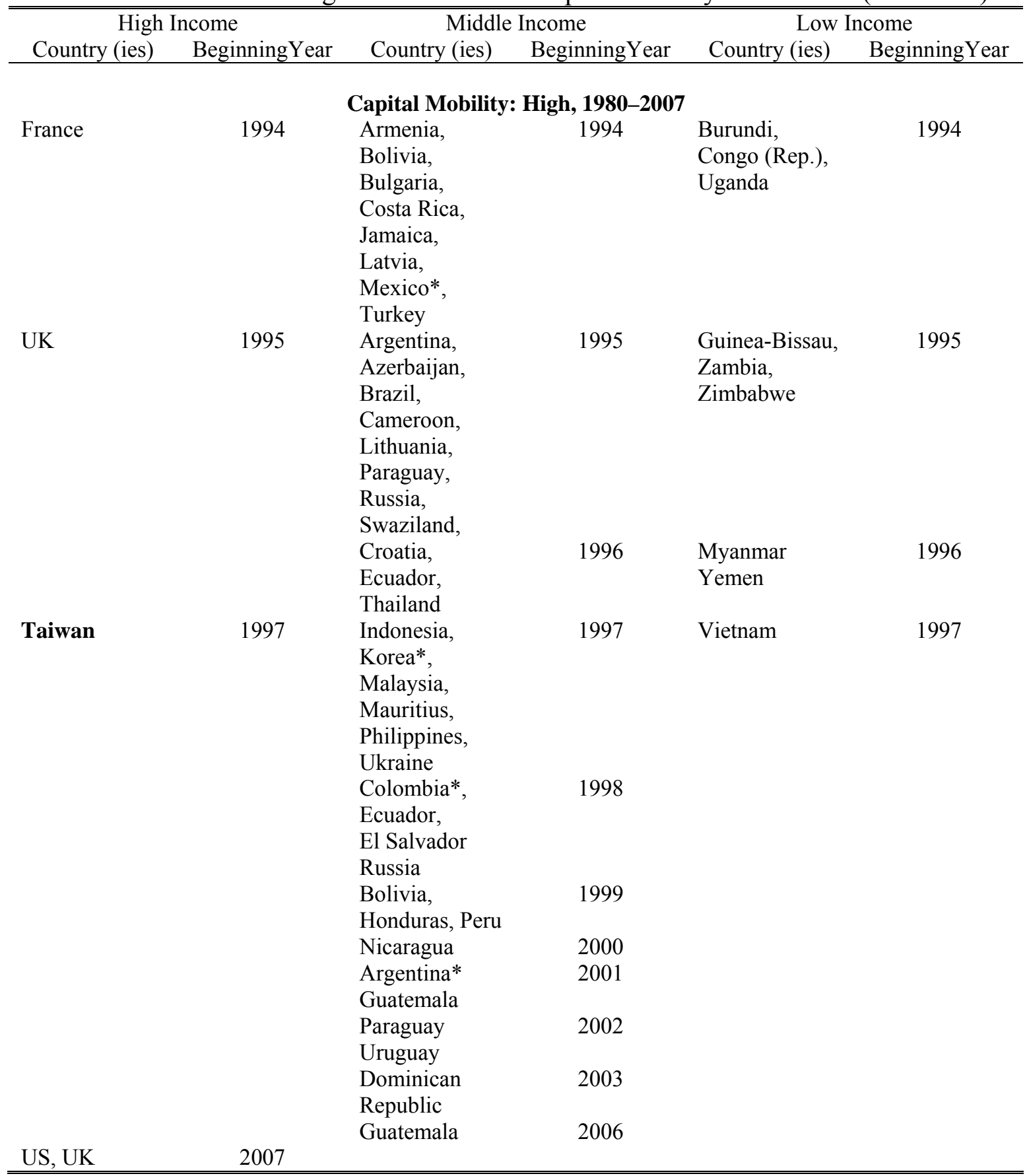

Note: An asterisk $\left({ }^{*}\right)$ denotes that the episode in question was associated with an output collapse as defined in Barro and Ursua (2008). However, many of the countries in our extended sample are not covered in Barro and Ursua (2008). 
Table A4. Real House Prices

\begin{tabular}{|c|c|c|c|}
\hline Country & Period covered & Source & Commentary \\
\hline Argentina & $1981-2007$ & Reporte Immobiliario & $\begin{array}{l}\text { Average value of old } \\
\text { apartments, Buenos } \\
\text { Aires }\end{array}$ \\
\hline Colombia & 1997:Q1-2007:Q4 & $\begin{array}{l}\text { Departamento } \\
\text { Administrativo Nacional } \\
\text { de Estadistica }\end{array}$ & $\begin{array}{l}\text { New housing price } \\
\text { index, total } 23 \\
\text { municipalities }\end{array}$ \\
\hline \multirow[t]{2}{*}{ Finland } & 1983:Q1-2008:Q1 & Stat-Fin Online Service & $\begin{array}{l}\text { Dwellings in old blocks } \\
\text { of flats, Finland }\end{array}$ \\
\hline & $1970-2007$ & $\begin{array}{l}\text { Bank of International } \\
\text { Settlements }\end{array}$ & $\begin{array}{l}\text { House price index, } \\
\text { Finland }\end{array}$ \\
\hline Hong Kong & 1991:7-2008:2 & Hong Kong University & $\begin{array}{l}\text { Real estate index series, } \\
\text { Hong Kong }\end{array}$ \\
\hline Hungary & $2000-2007$ & Otthon Centrum & $\begin{array}{l}\text { Average price of old } \\
\text { condominiums, } \\
\text { Budapest }\end{array}$ \\
\hline Iceland & 2000:3-2008:4 & Statistics Iceland & $\begin{array}{l}\text { House price index, } \\
\text { Iceland }\end{array}$ \\
\hline Indonesia & 1994:Q1-2008:Q1 & Bank of Indonesia & $\begin{array}{l}\text { Residential property } \\
\text { price index, new houses, } \\
\text { new developments, big } \\
\text { cities }\end{array}$ \\
\hline Ireland & 1996:Q1-2008:Q1 & ESRI/Permanent TSB & $\begin{array}{l}\text { House prices, } \\
\text { standardized, Ireland }\end{array}$ \\
\hline Japan & 1955:H1-2007:H2 & $\begin{array}{l}\text { Japan Real Estate } \\
\text { Institute }\end{array}$ & $\begin{array}{l}\text { Land prices, urban, } \\
\text { residential index, } \\
\text { Japan }\end{array}$ \\
\hline Malaysia & 2000:Q1-2007:Q4 & Bank Negara & $\begin{array}{l}\text { House price index, } \\
\text { Malaysia }\end{array}$ \\
\hline \multirow[t]{2}{*}{ Norway } & $1970-2007$ & $\begin{array}{l}\text { Bank of International } \\
\text { Settlements }\end{array}$ & $\begin{array}{l}\text { House price index, all } \\
\text { dwellings, Norway }\end{array}$ \\
\hline & 1819-2007 & Norges Bank & Housing prices, Norway \\
\hline Philippines & 1994:Q4-2007:Q4 & $\begin{array}{l}\text { Colliers International: } \\
\text { Philippines }\end{array}$ & $\begin{array}{l}\text { Prime 3-bedroom } \\
\text { condominium, Makati } \\
\text { Central Business } \\
\text { District }\end{array}$ \\
\hline \multirow[t]{2}{*}{ South Korea } & 1986:1-2006:12 & Kookmin Bank & Housing price index \\
\hline & 2007:Q1-2008:Q1 & Kookmin Bank & Housing price index \\
\hline \multirow[t]{2}{*}{ Spain } & 1990:Q1-2008:Q1 & Banco de España & $\begin{array}{l}\text { House price index, } \\
\text { appraised housing, } \\
\text { Spain }\end{array}$ \\
\hline & $1970-2007$ & $\begin{array}{l}\text { Bank of International } \\
\text { Settlements }\end{array}$ & $\begin{array}{l}\text { House price index, } \\
\text { appraised housing, } \\
\text { Spain }\end{array}$ \\
\hline Thailand & 1991:Q1-2007:Q & Bank of Thailand & $\begin{array}{l}\text { House price index, } \\
\text { single detached house }\end{array}$ \\
\hline United Kingdom & $\begin{array}{l}1952: 1-2008: 4 \\
1970-2007\end{array}$ & $\begin{array}{l}\text { Nationwide } \\
\text { Bank of International } \\
\text { Settlements }\end{array}$ & $\begin{array}{l}\text { Average house price UK } \\
\text { House price index, UK }\end{array}$ \\
\hline United States & $\begin{array}{l}\text { 1890-2007 } \\
\text { 1987:Q1-2008:Q2 }\end{array}$ & Standard and Poors & $\begin{array}{l}\text { Case-Shiller national } \\
\text { price index, US }\end{array}$ \\
\hline
\end{tabular}




\begin{tabular}{|c|c|c|c|}
\hline \multicolumn{4}{|c|}{ Table A5. Banking Crises: Historical Summaries } \\
\hline Country & Brief Summary & Year & Source \\
\hline Albania & $\begin{array}{l}\text { After the July } 1992 \text { cleanup, 31\% of "new" banking system loans were } \\
\text { nonperforming. Some banks faced liquidity problems due to a logjam of } \\
\text { interbank liabilities. }\end{array}$ & 1992 & $\begin{array}{l}\text { Caprio and Klingebiel } \\
(2003)\end{array}$ \\
\hline Algeria & $\begin{array}{l}\text { Circulation limits led to suspended specie payments. Lack of mortgage } \\
\text { banking institutes led bank to secure loans based on real estate—-many were } \\
\text { foreclosed to escape loss. }\end{array}$ & August 1870 & $\begin{array}{l}\text { Reinhart and Rogoff } \\
\text { (2008a); Conant (1915) }\end{array}$ \\
\hline Algeria & Share of nonperforming loans in the banking system reached 50\%. & $1990-1992$ & $\begin{array}{l}\text { Caprio and Klingebiel } \\
(2003)\end{array}$ \\
\hline Angola & Two state-owned commercial banks had insolvency problems. & $1991-1996$ & $\begin{array}{l}\text { Caprio and Klingebiel } \\
(2003)\end{array}$ \\
\hline \multirow[t]{10}{*}{ Argentina } & $\begin{array}{l}\text { Suspension of National Bank of the Argentine Republic; high foreign debt, } \\
\text { domestic credit, and imports led to reserve losses; peso fell } 27 \% \text { but the } \\
\text { crisis was brief and had relatively little impact on industrial production. }\end{array}$ & January, 1885 & $\begin{array}{l}\text { Bordo and Eichengreen } \\
\text { (1999); Conant (1915) }\end{array}$ \\
\hline & $\begin{array}{l}\text { Banks made extensive loans, and real estate prices rose dramatically with } \\
\text { excess bank note issue. Land prices fell by 50\%, and Bank of the Nation } \\
\text { could not pay its dividend, leading to a run, and the peso fell 36\% both } \\
\text { years. In July 1890, every bank of issue was suspended—-sent gold up 320\%. } \\
\text { In December 1890, the Bank of Argentine Nation replaced the old Bank of } \\
\text { the Nation. }\end{array}$ & July 1890-1891 & $\begin{array}{l}\text { Bordo and Eichengreen } \\
\text { (1999); Conant (1915) }\end{array}$ \\
\hline & $\begin{array}{l}\text { Bad harvests and European demands for liquidity due to the War led to bank } \\
\text { runs, with private banks losing } 45 \% \text { of deposits in two years. }\end{array}$ & 1914 & $\begin{array}{l}\text { Bordo and Eichengreen } \\
\text { (1999); Conant (1915); } \\
\text { Nakamura and Zarazaga } \\
\text { (2001) }\end{array}$ \\
\hline & End of gold standard with insolvent loans building. & 1931 & $\begin{array}{l}\text { Bordo et al. (2001); della } \\
\text { Paolera and Taylor } \\
\text { (1999) }\end{array}$ \\
\hline & $\begin{array}{l}\text { Huge loans to government and nonperforming assets building for many } \\
\text { years; finally all taken over by the new Central Bank. }\end{array}$ & 1934 & $\begin{array}{l}\text { Bordo et al. (2001); della } \\
\text { Paolera and Taylor } \\
\text { (1999) }\end{array}$ \\
\hline & $\begin{array}{l}\text { The failure of a large private bank (Banco de Intercambio Regional) led to } \\
\text { runs on three other banks. Eventually more than } 70 \text { institutions-16\% of } \\
\text { commercial bank assets and } 35 \% \text { of finance company assets—-were } \\
\text { liquidated or subjected to central bank intervention. }\end{array}$ & $\begin{array}{l}\text { March, } \\
1980-1982\end{array}$ & $\begin{array}{l}\text { Kaminsky and Reinhart } \\
\text { (1999); Caprio and } \\
\text { Klingebiel (2003); Bordo } \\
\text { et al. (2001) }\end{array}$ \\
\hline & $\begin{array}{l}\text { In early May, the government closed a large bank, leading to large runs, } \\
\text { which led the government to freeze dollar deposits on May } 19 .\end{array}$ & May, 1985 & $\begin{array}{l}\text { Kaminsky and Reinhart } \\
\text { (1999) }\end{array}$ \\
\hline & $\begin{array}{l}\text { Nonperforming assets accounted for } 27 \% \text { of aggregate portfolio and } 37 \% \text { of } \\
\text { state banks' portfolios. Failed banks held } 40 \% \text { of financial system assets. }\end{array}$ & $1989-1990$ & $\begin{array}{l}\text { Caprio and Klingebiel } \\
\text { (2003); Bordo et al. } \\
\text { (2001) }\end{array}$ \\
\hline & $\begin{array}{l}\text { The Mexican devaluation led to a run on banks, which resulted in an 18\% } \\
\text { decline in deposits between December and March. Eight banks suspended } \\
\text { and three banks collapsed. Through end of 1997, } 63 \text { of } 205 \text { banking } \\
\text { institutions were closed or merged. }\end{array}$ & $\begin{array}{l}\text { December, } \\
1994-1996\end{array}$ & $\begin{array}{l}\text { Reinhart (2002); Caprio } \\
\text { and Klingebiel (2003); } \\
\text { Bordo et al. (2001) }\end{array}$ \\
\hline & $\begin{array}{l}\text { In March 2001, a bank run started due to lack of public confidence in } \\
\text { government policy actions. In late November 2001, many banks were on the } \\
\text { verge of collapsing and partial withdrawal restrictions were imposed } \\
\text { (corralito) and fixed-term deposits (CDs) were reprogrammed to stop } \\
\text { outflows from banks (corralon). In December 2002, the corralito was lifted. } \\
\text { In January 2003, one bank was closed, three banks were nationalized, and } \\
\text { many others were reduced in size. }\end{array}$ & March, 2001 & $\begin{array}{l}\text { Caprio and Klingebiel } \\
\text { (2003); Jácome (2008) }\end{array}$ \\
\hline Armenia & $\begin{array}{l}\text { The Central Bank closed half the active banks; large banks continued to } \\
\text { suffer from a high level of nonperforming loans. The savings bank was } \\
\text { financially weak. }\end{array}$ & $\begin{array}{l}\text { August, } \\
1994-1996\end{array}$ & $\begin{array}{l}\text { Caprio and Klingebiel } \\
(2003)\end{array}$ \\
\hline
\end{tabular}




\begin{tabular}{|c|c|c|c|}
\hline Country & Brief Summary & Year & Source \\
\hline \multirow[t]{2}{*}{ Australia } & $\begin{array}{l}\text { Domestic lending boom showed the deteriorated quality of bank assets; land } \\
\text { boom and unregulated banking system led to speculation. Closure of } \\
\text { Mercantile Bank in Australia and Federal Bank of Australia meant British } \\
\text { deposits ran off. Bank share prices fell heavily, banks retrenched and } \\
\text { stopped long-term loans, and many closed. The depression of the 1890s } \\
\text { followed. }\end{array}$ & January, 1893 & $\begin{array}{l}\text { Bordo and Eichengreen } \\
\text { (1999); Conant (1915) }\end{array}$ \\
\hline & Two large banks received capital from government to cover losses. & 1989-1992 & $\begin{array}{l}\text { Caprio and Klingebiel } \\
\text { (2003); Bordo et al. } \\
\text { (2001); }\end{array}$ \\
\hline Austria & $\begin{array}{l}\text { Speculation in economy; Vienna Stock Exchange crash led } 52 \text { banks and } 44 \\
\text { provincial banks to fail. }\end{array}$ & May, 1873-1874 & Conant (1915) \\
\hline Austria & Difficulties in major bank; liquidation began in June. & May, 1923 & $\begin{array}{l}\text { Bernanke and James } \\
(1990)\end{array}$ \\
\hline Austria & Second largest bank failed and merged with major bank. & November, 1929 & $\begin{array}{l}\text { Bernanke and James } \\
(1990)\end{array}$ \\
\hline Austria & Failure of Creditanstalt and run of foreign depositors. & May, 1931 & $\begin{array}{l}\text { Bernanke and James } \\
(1990)\end{array}$ \\
\hline Azerbaijan & $\begin{array}{l}\text { Twelve private banks closed; three large state-owned banks deemed } \\
\text { insolvent and one faced serious liquidity problems. }\end{array}$ & 1995 & $\begin{array}{l}\text { Caprio and Klingebiel } \\
\text { (2003) }\end{array}$ \\
\hline Bangladesh & $\begin{array}{l}\text { Four banks, accounting for } 70 \% \text { of credit, had } 20 \% \text { nonperforming loans. } \\
\text { From the late } 1980 \text { s, the entire private and public banking system was } \\
\text { technically insolvent. }\end{array}$ & $1987-1996$ & $\begin{array}{l}\text { Caprio and Klingebiel } \\
\text { (2003); Bordo et al. } \\
\text { (2001) }\end{array}$ \\
\hline Belarus & $\begin{array}{l}\text { Many banks undercapitalized; forced mergers burdened some banks with } \\
\text { poor loan portfolios. }\end{array}$ & 1995 & $\begin{array}{l}\text { Caprio and Klingebiel } \\
\text { (2003) }\end{array}$ \\
\hline \multirow[t]{9}{*}{ Belgium } & $\begin{array}{l}\text { Two rival banks: Bank of Belgium (created in 1835) and Société Générale. } \\
\text { Fear of war led to credit contraction. Société tried to bankrupt the Bank of } \\
\text { Belgium by redeeming large amounts of credit, weakening both. Runs on } \\
\text { Bank of Belgium; did not suspend payment, but appealed to Treasury for } \\
\text { assistance. }\end{array}$ & $\begin{array}{l}\text { December, } \\
1838-1839\end{array}$ & Conant (1915) \\
\hline & $\begin{array}{l}\text { Bank of Belgium resigned its function of State depository to Société } \\
\text { Générale; Société felt impact of crisis—abandoned all branches except } \\
\text { Antwerp. }\end{array}$ & 1842 & Conant (1915) \\
\hline & $\begin{array}{l}\text { Société Générale suspended payments and lost right of issue after } \\
\text { government demands for reform. National Bank of Belgium created. }\end{array}$ & February, 1848 & Conant (1915) \\
\hline & $\begin{array}{l}\text { Public fear due to State decisions and burdens; but Bank of Belgium } \\
\text { reassured people by continuing payments (raised discount rate and placed } \\
\text { restrictions on acceptance of commercial paper)—great cost to commerce } \\
\text { and bank. }\end{array}$ & July, $1870-1871$ & Conant (1915) \\
\hline & $\begin{array}{l}\text { Worldwide investors dumped assets and withdrew liquidity, pushing prices } \\
\text { down and threatening financial institutions with failure. Stock exchanges } \\
\text { around the world collapsed. }\end{array}$ & 1914 & Bordo et al. (2001) \\
\hline & Consequence of systemic deflation led to a funding crisis. & $1925-1926$ & $\begin{array}{l}\text { Bordo et al. (2001); } \\
\text { Johnson (1998) }\end{array}$ \\
\hline & $\begin{array}{l}\text { Rumors about imminent failure of Bank of Bruselles, the largest bank, led to } \\
\text { withdrawals from all banks. Later, expectations of devaluations led to } \\
\text { withdrawals of foreign deposits. }\end{array}$ & May, 1931 & $\begin{array}{l}\text { Bordo et al. (2001); } \\
\text { Bernanke and James } \\
\text { (1990) }\end{array}$ \\
\hline & $\begin{array}{l}\text { Failure of Banque Belge de Travail developed into general banking and } \\
\text { exchange crisis. }\end{array}$ & 1934 & $\begin{array}{l}\text { Bordo et al. (2001); } \\
\text { Bernanke and James } \\
\text { (1990) }\end{array}$ \\
\hline & & 1939 & Bordo et al. (2001) \\
\hline Benin & $\begin{array}{l}\text { All three commercial banks collapsed and } 80 \% \text { of banks' loan portfolios } \\
\text { were nonperforming. }\end{array}$ & $1988-1990$ & $\begin{array}{l}\text { Caprio and Klingebiel } \\
\text { (2003) }\end{array}$ \\
\hline Bolivia & $\begin{array}{l}\text { In October 1987, the central bank liquidated two of twelve state commercial } \\
\text { banks; seven more reported large losses. In total, five banks were liquidated. } \\
\text { Banking system nonperforming loans reached } 30 \% \text { in } 1987 \text { and } 92 \% \text { by mid- } \\
1988 .\end{array}$ & $\begin{array}{l}\text { October, } \\
1987-1988\end{array}$ & $\begin{array}{l}\text { Kaminsky and Reinhart } \\
\text { (1999); Caprio and } \\
\text { Klingebiel (2003) }\end{array}$ \\
\hline
\end{tabular}




\begin{tabular}{|c|c|c|c|}
\hline Country & Brief Summary & Year & Source \\
\hline & $\begin{array}{l}\text { Two banks, with } 11 \% \text { of banking system assets, closed in } 1994 . \text { In } 1995 \text {, } \\
\text { four of } 15 \text { domestic banks, with } 30 \% \text { of banking system assets, experienced } \\
\text { liquidity problems and suffered a high level of nonperforming loans. }\end{array}$ & 1994 & $\begin{array}{l}\text { Caprio and Klingebiel } \\
(2003)\end{array}$ \\
\hline & $\begin{array}{l}\text { One small bank (with a market share of } 4.5 \% \text { of deposits) was intervened } \\
\text { and resolved. }\end{array}$ & 1999 & Jácome (2008) \\
\hline $\begin{array}{l}\text { Bosnia \& } \\
\text { Herzegovina }\end{array}$ & $\begin{array}{l}\text { Banking system suffered from a high level of nonperforming loans due to } \\
\text { the breakup of the former Yugoslavia and the civil war. }\end{array}$ & 1992-? & $\begin{array}{l}\text { Caprio and Klingebiel } \\
(2003)\end{array}$ \\
\hline Botswana & Banks merged, liquidated, or recapitalized. & $1994-1995$ & $\begin{array}{l}\text { Caprio and Klingebiel } \\
(2003)\end{array}$ \\
\hline \multirow[t]{11}{*}{ Brazil } & $\begin{array}{l}\text { Large government borrowing and currency speculation-the government } \\
\text { continually issued more notes. National Bank of Brazil and Bank of US of } \\
\text { Brazil merged into Bank of Republic of US of Brazil. The new bank retired } \\
\text { the government's paper notes. Financial-sector turmoil led to decline in } \\
\text { output. }\end{array}$ & $\begin{array}{l}\text { December, } \\
1890-1892\end{array}$ & $\begin{array}{l}\text { Bordo and Eichengreen } \\
\text { (1999); Conant (1915) }\end{array}$ \\
\hline & $\begin{array}{l}\text { Civil War and currency depreciation. A loan from Rothschild's in London } \\
\text { helped with an agreement on settling the loan. }\end{array}$ & $1897-1898$ & $\begin{array}{l}\text { Bordo and Eichengreen } \\
\text { (1999); Conant (1915) }\end{array}$ \\
\hline & $\begin{array}{l}\text { Inelastic coffee exports could not respond to currency depreciation; } \\
\text { concentrated industry, limited competition, and slowed recovery from } \\
\text { deflation. Liquidity injection did not help_-deposits ran off and loans } \\
\text { recalled. }\end{array}$ & $1900-1901$ & $\begin{array}{l}\text { Bordo and Eichengreen } \\
\text { (1999); Conant (1915) }\end{array}$ \\
\hline & & 1914 & Bordo et al. (2001) \\
\hline & & 1923 & Bordo et al. (2001) \\
\hline & & 1926 & \\
\hline & & 1929 & \\
\hline & & 1963 & Bordo et al. (2001) \\
\hline & $\begin{array}{l}\text { Three large banks (Comind, Maison Nave, and Auxiliar) were taken over by } \\
\text { the government. }\end{array}$ & November, 1985 & $\begin{array}{l}\text { Kaminsky and Reinhart } \\
\text { (1999) }\end{array}$ \\
\hline & Deposits converted to bonds. & 1990 & $\begin{array}{l}\text { Caprio and Klingebiel } \\
\text { (2003); Bordo et al. } \\
(2001)\end{array}$ \\
\hline & $\begin{array}{l}\text { In 1994, } 17 \text { small banks were liquidated, three private banks were } \\
\text { intervened, and eight state banks placed under administration. The Central } \\
\text { Bank intervened in or put under temporary administration } 43 \text { financial } \\
\text { institutions, and banking system nonperforming loans reached } 15 \% \text { by the } \\
\text { end of } 1997 . \text { Private banks returned to profitability in 1998, but public banks } \\
\text { did not begin to recover until } 1999 .\end{array}$ & July, 1994-1996 & $\begin{array}{l}\text { Kaminsky and Reinhart } \\
\text { (1999); Caprio and } \\
\text { Klingebiel (2003); Bordo } \\
\text { et al. (2001) }\end{array}$ \\
\hline Brunei & Several financial firms and banks failed. & 1986 & $\begin{array}{l}\text { Caprio and Klingebiel } \\
(2003)\end{array}$ \\
\hline Bulgaria & $\begin{array}{l}\text { In } 1995 \text {, about } 75 \% \text { of banking system loans were substandard. Banking } \\
\text { system run in early } 1996 . \text { The government stopped providing bailouts, } \\
\text { prompting the closure of } 19 \text { banks accounting for } 1 / 3 \text { of sector assets. } \\
\text { Surviving banks were recapitalized by } 1997 .\end{array}$ & $1995-1997$ & $\begin{array}{l}\text { Caprio and Klingebiel } \\
(2003)\end{array}$ \\
\hline Burkina Faso & Banking system nonperforming loans estimated at 34\%. & $1988-1994$ & $\begin{array}{l}\text { Caprio and Klingebiel } \\
(2003)\end{array}$ \\
\hline Burundi & $\begin{array}{l}\text { Banking system nonperforming loans estimated at 25\% in } 1995 \text { and one } \\
\text { bank was liquidated. }\end{array}$ & 1994 & $\begin{array}{l}\text { Caprio and Klingebiel } \\
(2003)\end{array}$ \\
\hline \multirow[t]{2}{*}{ Cameroon } & $\begin{array}{l}\text { In 1989, banking system nonperforming loans reached 60-70\%. Five } \\
\text { commercial banks were closed and three restructured. }\end{array}$ & 1987-1993 & $\begin{array}{l}\text { Caprio and Klingebiel } \\
(2003)\end{array}$ \\
\hline & $\begin{array}{l}\text { At the end of 1996, nonperforming loans were } 30 \% \text { of total loans. Two } \\
\text { banks were closed and three restructured. }\end{array}$ & 1995-1998 & $\begin{array}{l}\text { Caprio and Klingebiel } \\
(2003)\end{array}$ \\
\hline \multirow[t]{2}{*}{ Canada } & $\begin{array}{l}\text { Bank of Upper Canada and Gore Bank suspended specie payments; rebellion } \\
\text { in Lower Canada led to suspension of payments. }\end{array}$ & $\begin{array}{l}\text { November, } \\
1838-1839\end{array}$ & Conant (1915) \\
\hline & $\begin{array}{l}\text { Bank in Western Canada suspended payments, leading to financial panic. } \\
\text { Bank of Upper Canada failed; rapid growth in Ontario-lost capital in land } \\
\text { speculation in 1857; abandoned safe banking practices and made loans to } \\
\text { lawyers, politicians, and gentry. }\end{array}$ & September, 1866 & Conant (1915) \\
\hline
\end{tabular}




\begin{tabular}{|c|c|c|c|}
\hline Country & Brief Summary & Year & Source \\
\hline & Several bank failures; depression from 1874-1879. & September, 1873 & Conant (1915) \\
\hline & $\begin{array}{l}\text { Ontario Bank failed due to speculation in NY stock market; shareholders } \\
\text { lose entire investments. }\end{array}$ & October, 1906 & Conant (1915) \\
\hline & $\begin{array}{l}\text { Current account deficit and a crop failure meant eastern banks were } \\
\text { unwilling to ship funds west; banks raised loan rates, cut lending, and } \\
\text { limited credit to farmers. Short but sharp recession; Canadian banks } \\
\text { borrowed dominion notes and banks increased note issue. }\end{array}$ & January, 1908 & $\begin{array}{l}\text { Bordo and Eichengreen } \\
\text { (1999); Conant (1915) }\end{array}$ \\
\hline & Royal Bank acquired Bank of British Honduras and Bank of British Guiana. & 1912 & Conant (1915) \\
\hline & Home Bank of Canada, with over 70 branches, failed due to bad loans. & 1923 & $\begin{array}{l}\text { Bordo et al. (2001); } \\
\text { Kryzanowski and Roberts } \\
\text { (1999) }\end{array}$ \\
\hline & $\begin{array}{l}\text { Fifteen members of the Canadian Deposit Insurance Corporation, including } \\
\text { two banks, failed. }\end{array}$ & $1983-1985$ & $\begin{array}{l}\text { Caprio and Klingebiel } \\
\text { (2003); Bordo et al. } \\
\text { (2001) }\end{array}$ \\
\hline Cape Verde & At the end of 1995, commercial banks' nonperforming loans reached 30\%. & 1993 & $\begin{array}{l}\text { Caprio and Klingebiel } \\
(2003)\end{array}$ \\
\hline \multirow[t]{2}{*}{$\begin{array}{l}\text { Central African } \\
\text { Republic }\end{array}$} & Four banks were liquidated. & 1976-1982 & $\begin{array}{l}\text { Caprio and Klingebiel } \\
\text { (2003) }\end{array}$ \\
\hline & $\begin{array}{l}\text { The two largest banks, with } 90 \% \text { of assets, were restructured. Banking } \\
\text { system nonperforming loans reached } 40 \% \text {. }\end{array}$ & 1988-1999 & $\begin{array}{l}\text { Caprio and Klingebiel } \\
\text { (2003) }\end{array}$ \\
\hline Chad & Banking sector experienced solvency problems. & 1980s & $\begin{array}{l}\text { Caprio and Klingebiel } \\
\text { (2003) }\end{array}$ \\
\hline \multirow[t]{7}{*}{ Chad } & Private sector nonperforming loans reached $35 \%$. & 1992 & $\begin{array}{l}\text { Caprio and Klingebiel } \\
(2003)\end{array}$ \\
\hline & $\begin{array}{l}\text { Bank currency system and gold standard completely wrecked by threat of } \\
\text { war with Argentine Republic. On July 5th, growing exports of gold and } \\
\text { Bank of Chile’s refusal to honor gold drafts led to a run on banks at Santiago } \\
\text { and general suspicion of gold drafts. The government issued irredeemable } \\
\text { paper money, constantly increasing the monetary supply for the next } 10 \\
\text { years, leading to a period of inflation and overspeculation. }\end{array}$ & July, 1898 & $\begin{array}{l}\text { Bordo and Eichengreen } \\
\text { (1999); Conant (1915) }\end{array}$ \\
\hline & $\begin{array}{l}\text { Four years of inflationary measures following a stock market crash; the peso } \\
\text { fell } 30 \% \text { during the crisis, and the government loaned treasury notes to } \\
\text { banks to prevent a financial sector crisis. Data concerning the ensuing } \\
\text { recession are unavailable. }\end{array}$ & 1907 & $\begin{array}{l}\text { Bordo and Eichengreen } \\
\text { (1999); Conant (1915) }\end{array}$ \\
\hline & & 1914 & Bordo et al. (2001) \\
\hline & & 1925 & Bordo et al. (2001) \\
\hline & Entire mortgage system insolvent. & 1976 & $\begin{array}{l}\text { Caprio and Klingebiel } \\
\text { (2003); Bordo et al. } \\
\text { (2001) }\end{array}$ \\
\hline & $\begin{array}{l}\text { Three banks began to lose deposits; interventions began two months later. } \\
\text { Interventions occurred in four banks and four nonbank financial institutions, } \\
\text { accounting for } 33 \% \text { of outstanding loans. In 1983, there were seven more } \\
\text { bank interventions and one financiera, accounting for } 45 \% \text { of financial } \\
\text { system assets. By the end of 1983, 19\% of loans were nonperforming. }\end{array}$ & $\begin{array}{l}\text { September, } \\
\text { 1981-1985 }\end{array}$ & $\begin{array}{l}\text { Kaminsky and Reinhart } \\
\text { (1999); Caprio and } \\
\text { Klingebiel (2003); Bordo } \\
\text { et al. (2001) }\end{array}$ \\
\hline China & $\begin{array}{l}\text { Failure of a major silk-trading company in Shanghai led to the bankruptcies } \\
\text { of many local banks. }\end{array}$ & 1883 & Cheng (2003) \\
\hline \multirow[t]{4}{*}{ China } & Postwar depression led many banks to fail. & 1923-1925 & Young 1971 \\
\hline & Shanghai closed all Chinese banks for the duration of the war. & 1931 & Cheng (2003) \\
\hline & $\begin{array}{l}\text { Flight of silver led to huge economic downturn and financial crisis; the two } \\
\text { major banks came under government control and were reorganized. }\end{array}$ & $1934-1937$ & Cheng (2003) \\
\hline & $\begin{array}{l}\text { China's four large state-owned commercial banks, with } 68 \% \text { of banking } \\
\text { system assets, were deemed insolvent. Banking system nonperforming loans } \\
\text { were estimated at } 50 \% \text {. }\end{array}$ & $1997-1999$ & $\begin{array}{l}\text { Caprio and Klingebiel } \\
(2003)\end{array}$ \\
\hline
\end{tabular}




\begin{tabular}{|c|c|c|c|}
\hline Country & Brief Summary & Year & Source \\
\hline \multirow[t]{2}{*}{ Colombia } & $\begin{array}{l}\text { Banco Nacional became the first of six major banks and eight financial } \\
\text { companies to be intervened, accounting for } 25 \% \text { of banking system assets. }\end{array}$ & July, 1982-1987 & $\begin{array}{l}\text { Kaminsky and Reinhart } \\
\text { (1999); Caprio and } \\
\text { Klingebiel (2003); Bordo } \\
\text { et al. (2001) }\end{array}$ \\
\hline & $\begin{array}{l}\text { Many banks and financial institutions failed; capitalization ratios and } \\
\text { liquidity decreased dramatically, and total assets of the financial industry } \\
\text { contracted by over } 20 \% \text {. }\end{array}$ & April, 1998 & $\begin{array}{l}\text { Reinhart (2002); Jácome } \\
\text { (2008) }\end{array}$ \\
\hline $\begin{array}{l}\text { Congo, Democratic } \\
\text { Republic }\end{array}$ & Banking sector experienced solvency problems. & 1980s & $\begin{array}{l}\text { Caprio and Klingebiel } \\
(2003)\end{array}$ \\
\hline $\begin{array}{l}\text { Congo, Democratic } \\
\text { Republic }\end{array}$ & $\begin{array}{l}\text { Four state-owned banks were insolvent; a fifth was recapitalized with private } \\
\text { participation. }\end{array}$ & $1991-1992$ & $\begin{array}{l}\text { Caprio and Klingebiel } \\
(2003)\end{array}$ \\
\hline $\begin{array}{l}\text { Congo, Democratic } \\
\text { Republic }\end{array}$ & $\begin{array}{l}\text { Nonperforming loans reached 75\%. Two state-owned banks liquidated and } \\
\text { two privatized. In 1997, } 12 \text { banks had serious financial difficulties. }\end{array}$ & 1994-? & $\begin{array}{l}\text { Caprio and Klingebiel } \\
(2003)\end{array}$ \\
\hline Congo, Republic of & $\begin{array}{l}\text { Crisis began in 1992. In 2001-2002, two large banks were restructured and } \\
\text { privatized. Remaining insolvent bank being liquidated. }\end{array}$ & 1992-? & $\begin{array}{l}\text { Caprio and Klingebiel } \\
(2003)\end{array}$ \\
\hline \multirow[t]{2}{*}{ Costa Rica } & $\begin{array}{l}\text { In 1987, public banks accounting for } 90 \% \text { of banking system loans were in } \\
\text { financial distress, with } 32 \% \text { of loans considered uncollectable. }\end{array}$ & 1987 & $\begin{array}{l}\text { Caprio and Klingebiel } \\
\text { (2003); Bordo et al. } \\
(2001)\end{array}$ \\
\hline & $\begin{array}{l}\text { The third largest bank, Banco Anglo Costarricense, a state-owned institution } \\
\text { with } 17 \% \text { of deposits was closed. }\end{array}$ & 1994-1997 & $\begin{array}{l}\text { Caprio and Klingebiel } \\
\text { (2003); Bordo et al. } \\
\text { (2001); Jácome (2008) }\end{array}$ \\
\hline Cote D'Ivoire & $\begin{array}{l}\text { Four large banks ( } 90 \% \text { of banking system loans) were affected; three or four } \\
\text { insolvent, six government banks closed. }\end{array}$ & $1988-1991$ & $\begin{array}{l}\text { Caprio and Klingebiel } \\
\text { (2003); Bordo et al. } \\
(2001)\end{array}$ \\
\hline Croatia & $\begin{array}{l}\text { Five banks, accounting for about half of banking system loans, were deemed } \\
\text { insolvement and taken over by the Bank Rehabilitation Agency. }\end{array}$ & 1996 & $\begin{array}{l}\text { Caprio and Klingebiel } \\
(2003)\end{array}$ \\
\hline Czechoslovakia & $\begin{array}{l}\text { Withdrawal of foreign deposits sparked domestic withdrawals but no general } \\
\text { banking panic. }\end{array}$ & July, 1931 & $\begin{array}{l}\text { Bernanke and James } \\
(1990)\end{array}$ \\
\hline Czech Republic & $\begin{array}{l}\text { Several bank closings since 1993. In 1994-1995, 38\% of banking system } \\
\text { loans were nonperforming. }\end{array}$ & 1991-? & $\begin{array}{l}\text { Caprio and Klingebiel } \\
(2003)\end{array}$ \\
\hline Czech Republic & & 1994 & \\
\hline \multirow[t]{10}{*}{ Denmark } & $\begin{array}{l}\text { Government declared it could not redeem Deposit Bank’s Courant notes at } \\
\text { original value-form of bankruptcy which diminished its public debt } \\
\text { because notes were held by the people. New Royal Bank established; } \\
\text { Courantbank, Specie Bank, and Deposit Bank abolished. }\end{array}$ & January, 1813 & Conant (1915) \\
\hline & $\begin{array}{l}\text { Financial crisis led the National bank to assume central bank responsibilities } \\
\text { through the } 1860 \text { s. }\end{array}$ & 1857 & $\begin{array}{l}\text { Jonung and Hagberg } \\
(2002)\end{array}$ \\
\hline & $\begin{array}{l}\text { Industrial Bank diverted half its capital stock to cover losses; two provincial } \\
\text { banks failed-led to lull in banking business. }\end{array}$ & 1877 & $\begin{array}{l}\text { Conant (1915); Jonung } \\
\text { and Hagberg (2002) }\end{array}$ \\
\hline & $\begin{array}{l}\text { National Bank intervened to provide support for commercial and savings } \\
\text { banks. }\end{array}$ & 1885 & $\begin{array}{l}\text { Jonung and Hagberg } \\
(2002)\end{array}$ \\
\hline & $\begin{array}{l}\text { Important bank failure led to suspension of Freeholders’ Bank and bank run } \\
\text { on other institutions. The National Bank helped alleviate panic_-took on } \\
\text { five remaining banks and suspended banks’ liabilities. }\end{array}$ & February, 1902 & Conant (1915) \\
\hline & $\begin{array}{l}\text { Turbulence in the world markets and Germany and nonperforming assets led } \\
\text { to decreased confidence. Consortium of five leading banks assisted and } \\
\text { guaranteed the liabilities of weak banks, leading to a quick recovery. }\end{array}$ & 1907 & $\begin{array}{l}\text { Bordo and Eichengreen } \\
\text { (1999); Conant (1915); } \\
\text { Jonung and Hagberg } \\
\text { (2002) }\end{array}$ \\
\hline & & 1914 & Bordo et al. (2001) \\
\hline & $\begin{array}{l}\text { Banking crises lasted for many years due to reckless lending during the war } \\
\text { and the international downswing in prices in the early 1920s. }\end{array}$ & 1921 & $\begin{array}{l}\text { Bordo et al. (2001); } \\
\text { Jonung and Hagberg } \\
(2002)\end{array}$ \\
\hline & & 1931 & Bordo et al. (2001) \\
\hline & $\begin{array}{l}\text { Two small banks collapsed and shook the banking system leading to moves } \\
\text { to curb bank lending. Cumulative losses over 1990-92 were } 9 \% \text { of loans; } 40 \\
\text { of } 60 \text { problem banks were merged. }\end{array}$ & $\begin{array}{l}\text { March, } \\
\text { 1987-1992 }\end{array}$ & $\begin{array}{l}\text { Kaminsky and Reinhart } \\
\text { (1999); Caprio and } \\
\text { Klingebiel (2003); Bordo } \\
\text { et al. (2001) }\end{array}$ \\
\hline
\end{tabular}




\begin{tabular}{|c|c|c|c|}
\hline Country & Brief Summary & Year & Source \\
\hline & Deep Faroese crisis. & 1992 & \\
\hline Djibouti & $\begin{array}{l}\text { Two of six commercial banks ceased operations and other banks } \\
\text { experienced difficulties. }\end{array}$ & $1991-1993$ & $\begin{array}{l}\text { Caprio and Klingebiel } \\
(2003)\end{array}$ \\
\hline \multirow[t]{2}{*}{$\begin{array}{l}\text { Dominican } \\
\text { Republic }\end{array}$} & The third largest bank, with a market share of $7 \%$ of assets, was intervened. & 1996 & Jácome (2008) \\
\hline & $\begin{array}{l}\text { The } 2003 \text { banking crisis started with the intervention of the third largest } \\
\text { bank-with a market share of } 10 \% \text {. Deposit withdrawals had already started } \\
\text { by mid-2002, following allegations of fraud resulting from the discovery of } \\
\text { hidden liabilities recorded in a "parallel bank.” Immediately after, the crisis } \\
\text { extended to two other institutions-with an additional } 10 \% \text { of market } \\
\text { share-featuring similar inappropriate accounting practices. }\end{array}$ & 2003 & Jácome (2008) \\
\hline \multirow[t]{4}{*}{ Ecuador } & $\begin{array}{l}\text { Program exchanging domestic for foreign debt implemented to bail out } \\
\text { banking system. }\end{array}$ & 1981 & $\begin{array}{l}\text { Caprio and Klingebiel } \\
\text { (2003); Bordo et al. } \\
\text { (2001) }\end{array}$ \\
\hline & $\begin{array}{l}\text { A medium-sized bank, Banco de los Andes, with a market share of } 6 \% \text { of } \\
\text { deposits, was intervened and then purchased by another private bank. }\end{array}$ & 1994 & Jácome (2008) \\
\hline & $\begin{array}{l}\text { Authorities intervened in several small financial institutions; by the end of } \\
\text { 1995, } 30 \text { financial societies (sociedades financieras) and seven banks were } \\
\text { receiving extensive liquidity support. In early 1996, the fifth largest } \\
\text { commercial bank was intervened. }\end{array}$ & Late 1995-1997 & $\begin{array}{l}\text { Caprio and Klingebiel } \\
\text { (2003); Bordo et al. } \\
\text { (2001) }\end{array}$ \\
\hline & $\begin{array}{l}60 \% \text { of the banking system was intervened, taken over, or closed. Seven } \\
\text { financial institutions, accounting for 25-30\% of commercial banking assets, } \\
\text { were closed in 1998-99. In March 1999, bank deposits were frozen for six } \\
\text { months. By January 2000, } 16 \text { financial institutions, accounting for } 65 \% \text { of } \\
\text { the assets, had either been closed (12) or taken over (four) by the } \\
\text { governments. All deposits were unfrozen by March } 2000 .\end{array}$ & April, 1998-1999 & $\begin{array}{l}\text { Caprio and Klingebiel } \\
\text { (2003); Jácome (2008) }\end{array}$ \\
\hline Egypt & Crisis due to credit abuse and issue of new securities. & March, 1907 & Conant (1915) \\
\hline \multirow[t]{3}{*}{ Egypt } & Run on Cairo and Alexandria branches of German banks. & July, 1931 & $\begin{array}{l}\text { Bernanke and James } \\
(1990)\end{array}$ \\
\hline & The government closed several large investment companies. & $\begin{array}{l}\text { January, } \\
1980-1981\end{array}$ & $\begin{array}{l}\text { Reinhart (2002); Caprio } \\
\text { and Klingebiel (2003); } \\
\text { Bordo et al. (2001) }\end{array}$ \\
\hline & Four public banks were given capital assistance. & $\begin{array}{l}\text { January, } \\
\text { 1990-1995 }\end{array}$ & $\begin{array}{l}\text { Caprio and Klingebiel } \\
\text { (2003); Reinhart (2002); } \\
\text { Bordo et al. (2001) }\end{array}$ \\
\hline \multirow[t]{2}{*}{ El Salvador } & $\begin{array}{l}\text { Nine state-owned commercial banks had nonperforming loans averaging } \\
37 \% \text {. }\end{array}$ & 1989 & $\begin{array}{l}\text { Caprio and Klingebiel } \\
\text { (2003) }\end{array}$ \\
\hline & $\begin{array}{l}\text { After a sharp stop in economic growth in } 1996 \text { associated with a terms-of- } \\
\text { trade deterioration (decline in coffee prices), the financial system got into } \\
\text { stress from } 1997 \text { onwards. A small- to medium-sized institution (Banco } \\
\text { Credisa), with a 5\% market share, was closed. }\end{array}$ & 1998 & Jácome (2008) \\
\hline Equatorial Guinea & Two of the country's largest banks were liquidated. & $1983-1985$ & $\begin{array}{l}\text { Caprio and Klingebiel } \\
\text { (2003) }\end{array}$ \\
\hline Eritrea & Most of the banking system insolvent. & 1993 & $\begin{array}{l}\text { Caprio and Klingebiel } \\
\text { (2003) }\end{array}$ \\
\hline Estonia & Failure of two medium-sized banks; panic lasts until January. & November, 1930 & $\begin{array}{l}\text { Bernanke and James } \\
\text { (1990) }\end{array}$ \\
\hline Estonia & Waves of general bank runs. & September, 1931 & $\begin{array}{l}\text { Bernanke and James } \\
(1990)\end{array}$ \\
\hline Estonia & $\begin{array}{l}\text { Insolvent banks accounted for } 41 \% \text { of financial system assets. Five banks' } \\
\text { licenses were revoked and two major banks were merged and nationalized } \\
\text { while two more merged and were converted to a loan recovery agency. }\end{array}$ & $1992-1995$ & $\begin{array}{l}\text { Caprio and Klingebiel } \\
\text { (2003) }\end{array}$ \\
\hline Estonia & The Social Bank, with $10 \%$ of financial system assets, failed. & 1994 & \\
\hline Estonia & Three banks failed in 1998. & 1998 & $\begin{array}{l}\text { Caprio and Klingebiel } \\
\text { (2003) }\end{array}$ \\
\hline Ethiopia & Government-owned bank restructured and nonperforming loans taken over. & $1994-1995$ & $\begin{array}{l}\text { Caprio and Klingebiel } \\
(2003)\end{array}$ \\
\hline
\end{tabular}




\begin{tabular}{|c|c|c|c|}
\hline Country & Brief Summary & Year & Source \\
\hline Finland & $\begin{array}{l}\text { Crisis in Russia and Balkans and export prices put the finance sector at risk. } \\
\text { The Bank of Finland extended loans, extended note issues, but the growth } \\
\text { rate of real GDP still fell by } 4 \% \text {. }\end{array}$ & 1900 & $\begin{array}{l}\text { Bordo and Eichengreen } \\
\text { (1999) }\end{array}$ \\
\hline Finland & Fared better than other Nordic countries. & 1921 & $\begin{array}{l}\text { Bordo et al. (2001); } \\
\text { Jonung and Hagberg } \\
(2002)\end{array}$ \\
\hline Finland & $\begin{array}{l}\text { Recession began in 1929; many banks were stuck with large losses, which } \\
\text { led to bankruptcies; the Bank of Finland faciliated with loans and mergers. }\end{array}$ & 1931 & $\begin{array}{l}\text { Bordo et al. (2001); } \\
\text { Jonung and Hagberg } \\
(2002)\end{array}$ \\
\hline Finland & Financial stability was maintained and GDP growth did not suffer too much. & 1939 & $\begin{array}{l}\text { Bordo et al. (2001); } \\
\text { Jonung and Hagberg } \\
(2002)\end{array}$ \\
\hline Finland & $\begin{array}{l}\text { A large bank (Skopbank) collapsed on September } 19 \text { and was intervened. } \\
\text { Savings banks were badly affected; the government took control of three } \\
\text { banks that together accounted for } 31 \% \text { of system deposits. }\end{array}$ & $\begin{array}{l}\text { September, } \\
1991-1994\end{array}$ & $\begin{array}{l}\text { Kaminsky and Reinhart } \\
\text { (1999); Caprio and } \\
\text { Klingebiel (2003); Bordo } \\
\text { et al. (2001); Jonung and } \\
\text { Hagberg (2002) }\end{array}$ \\
\hline France & Bank of France: "serious crisis.” & 1802 & Conant (1915) \\
\hline France & $\begin{array}{l}\text { Bank of France: Debt of } 68 \mathrm{~m} \text { fr with only } 0.782 \mathrm{~m} \text { fr in specie; used } \\
\text { commercial paper, government bonds, and credit to buy specie (Spain, } \\
\text { Treasury); occurred after formation of third coalition against France during } \\
\text { preparations for Austerlitz; victory at Austerlitz (Dec. 2, 1805) restored } \\
\text { much confidence. }\end{array}$ & $\begin{array}{l}\text { September, } \\
1805-1806\end{array}$ & Conant (1915) \\
\hline France & Bankruptcies in Alsace. & $\begin{array}{l}\text { December, } \\
1827-1828\end{array}$ & Conant (1915) \\
\hline France & Severe runs on banks in Paris after Bank of Belgium failed. & $\begin{array}{l}\text { December, } \\
1838-1839\end{array}$ & Conant (1915) \\
\hline France & $\begin{array}{l}\text { March 24, 1848: notes from Bank of France and departmental banks } \\
\text { declared legal tender; necessity for uniform paper currency led to } \\
\text { consolidation of local banks with Bank of France (April } 27 \text { and May 2). }\end{array}$ & $\begin{array}{l}\text { February, } \\
1848-1850\end{array}$ & Conant (1915) \\
\hline France & French panic after cotton speculation. & January, 1864 & Conant (1915) \\
\hline France & French crisis after failure of Credit Mobilier. & $\begin{array}{l}\text { November, } \\
1867-1868 \\
\end{array}$ & Conant (1915) \\
\hline France & $\begin{array}{l}\text { Suspension of operations by branches of Bank of France. After surrender, } \\
\text { Germany suspended Bank of Strasburg, and the Bank of Prussia replaced } \\
\text { Bank of France in Alsace-Lorraine. }\end{array}$ & May, 1871 & Conant (1915) \\
\hline France & $\begin{array}{l}\text { Speculation and financial innovation led to problems among banks; Bank of } \\
\text { France extended loans to smaller banks and borrowed from the Bank of } \\
\text { England to replenish reserves. Growth fell by 5\% that year and failed to } \\
\text { recover to previous trend for a long time. }\end{array}$ & February, 1882 & $\begin{array}{l}\text { Bordo and Eichengreen } \\
\text { (1999); Conant (1915) }\end{array}$ \\
\hline France & $\begin{array}{l}\text { France financier's attempt to corner the copper market while the Comptoir } \\
\text { d'Escompte discounted copper warrants; product limits broke down and } \\
\text { copper prices fell so the Comptoir suffered heavy losses. The head } \\
\text { committed suicide, leading to a run-sound assets could not satisfy liquidity } \\
\text { demands. Comptoir appealed to Bank of France for help; growth fell by } 14 \% \\
\text { during the crisis. }\end{array}$ & March, 1889 & $\begin{array}{l}\text { Bordo and Eichengreen } \\
\text { (1999); Conant (1915) }\end{array}$ \\
\hline France & $\begin{array}{l}\text { French banking panic; depression in Bourse since beginning of } \\
\text { Russo-Japanese War. }\end{array}$ & February, 1904 & Conant (1915) \\
\hline France & $\begin{array}{l}\text { Trouble in the United States raised global demand for gold and money; } \\
\text { majority of France's losses were in silver to its colonies. As a result, visible } \\
\text { impact on GDP growth was mild. }\end{array}$ & 1907 & $\begin{array}{l}\text { Bordo and Eichengreen } \\
\text { (1999); Conant (1915) }\end{array}$ \\
\hline France & Failure of two major banks; runs on provincial banks. & $1930-1932$ & $\begin{array}{l}\text { Bordo et al. (2001); } \\
\text { Bernanke and James } \\
(1990)\end{array}$ \\
\hline
\end{tabular}




\begin{tabular}{|c|c|c|c|}
\hline Country & Brief Summary & Year & Source \\
\hline France & Crédit Lyonnaise had serious solvency problems. & $1994-1995$ & $\begin{array}{l}\text { Caprio and Klingebiel } \\
\text { (2003); Bordo et al. } \\
\text { (2001) }\end{array}$ \\
\hline Gabon & One bank temporarily closed in 1995. & 1995 & $\begin{array}{l}\text { Caprio and Klingebiel } \\
(2003)\end{array}$ \\
\hline Gambia & In 1992, a government bank was restructured and privatized. & $1985-1992$ & $\begin{array}{l}\text { Caprio and Klingebiel } \\
\text { (2003) }\end{array}$ \\
\hline Georgia & $\begin{array}{l}\text { Most large banks virtually insolvent. About 1/3 of banking system loans } \\
\text { were nonperforming. }\end{array}$ & 1991 & $\begin{array}{l}\text { Caprio and Klingebiel } \\
(2003)\end{array}$ \\
\hline Germany & $\begin{array}{l}\text { Hamburg Bank: rescued by Austrian National Bank; restored confidence, } \\
\text { dispelled crisis; repaid loan in six months. }\end{array}$ & 1857 & Conant (1915) \\
\hline Germany & $\begin{array}{l}\text { Triggered by Russia's crisis; stock prices in Berlin fell by } 61 \% \text {; hit mortgage } \\
\text { banks first, but discount banks provided liquidity. Dresdner Creditanstalt, } \\
\text { Bank of Leipzig, and Leipzig Bank failed. Modest slowdown in the rate of } \\
\text { growth. }\end{array}$ & 1901 & $\begin{array}{l}\text { Bordo and Eichengreen } \\
\text { (1999); Conant (1915) }\end{array}$ \\
\hline Germany & $\begin{array}{l}\text { Twin crisis in which banks were recapitalized or their deposits guaranteed } \\
\text { by the government. Bank runs exacerbated troubles building since mid-1930; } \\
\text { many banks unable to make payments and there was a bank holiday. }\end{array}$ & 1931 & $\begin{array}{l}\text { Bordo et al. (2001); } \\
\text { Temin (2008); Bernanke } \\
\text { and James (1990) }\end{array}$ \\
\hline Germany & Giro institutions faced problems. & late 1970s & $\begin{array}{l}\text { Caprio and Klingebiel } \\
\text { (2003) }\end{array}$ \\
\hline Ghana & 7/11 banks insolvent; rural banking sector affected. & $1982-1989$ & $\begin{array}{l}\text { Caprio and Klingebiel } \\
\text { (2003); Bordo et al. } \\
\text { (2001) }\end{array}$ \\
\hline Ghana & $\begin{array}{l}\text { Nonperforming loans increased } 11 \% \text { to } 27 \% \text {; two state-owned banks were in } \\
\text { bad shape and three others insolvent. }\end{array}$ & 1997 & $\begin{array}{l}\text { Caprio and Klingebiel } \\
\text { (2003); Bordo et al. } \\
\text { (2001) }\end{array}$ \\
\hline Greece & & 1931 & Bordo et al. (2001) \\
\hline Greece & Localized problems required significant injections of public funds. & $1991-1995$ & $\begin{array}{l}\text { Caprio and Klingebiel } \\
\text { (2003); Reinhart (2002), } \\
\text { Bordo et al. (2001) }\end{array}$ \\
\hline \multirow[t]{3}{*}{ Guatemala } & $\begin{array}{l}\text { Two small state-owned banks had a high level of nonperforming operations; } \\
\text { closed in early 1990s. }\end{array}$ & 1991 & $\begin{array}{l}\text { Caprio and Klingebiel } \\
(2003)\end{array}$ \\
\hline & $\begin{array}{l}\text { Three small banks (Banco Empresarial, Promotor, and Metropolitano), with } \\
\text { a market share of } 7 \% \text { of deposits, were intervened and later closed for not } \\
\text { observing solvency requirements. }\end{array}$ & 2001 & Jácome (2008) \\
\hline & $\begin{array}{l}\text { The third largest bank, Bancafe (with } 9 \% \text { of deposits), was closed followed } \\
\text { by another small bank, Banco del Comercio (with } 1 \% \text { of deposits), a few } \\
\text { months later. }\end{array}$ & 2006 & Jácome (2008) \\
\hline Guinea & Six banks (with 99\% of system deposits) deemed insolvent. & & $\begin{array}{l}\text { Caprio and Klingebiel } \\
(2003)\end{array}$ \\
\hline Guinea & $\begin{array}{l}\text { Two banks insolvent, one other had serious financial difficulties_- } 45 \% \text { of } \\
\text { market total. }\end{array}$ & $1993-1994$ & $\begin{array}{l}\text { Caprio and Klingebiel } \\
(2003)\end{array}$ \\
\hline Guinea-Bissau & $\begin{array}{l}\text { End of } 1995,45 \% \text { of commerical banks' loan portfolios were } \\
\text { nonperforming. }\end{array}$ & 1995 & $\begin{array}{l}\text { Caprio and Klingebiel } \\
(2003)\end{array}$ \\
\hline Honduras & A small bank, Bancorp, with 3\% of deposits, was closed in September 1999. & 1999 & Jácome (2008) \\
\hline \multirow[t]{2}{*}{ Honduras } & A small bank, Banhcreser, with 3\% of market share, was closed. & 2001-2002 & Jácome (2008) \\
\hline & $\begin{array}{l}\text { Two small banks, Banco Sogerin and Banco Capital were intervened and } \\
\text { taken over by the deposit insurance institution. }\end{array}$ & & Jácome (2008) \\
\hline Hong Kong & Nine deposit-taking companies failed. & 1982 & $\begin{array}{l}\text { Caprio and Klingebiel } \\
\text { (2003); Bordo et al. } \\
\text { (2001) }\end{array}$ \\
\hline Hong Kong & Seven banks liquidated or taken over. & $1983-1986$ & $\begin{array}{l}\text { Caprio and Klingebiel } \\
\text { (2003); Bordo et al. } \\
\text { (2001) }\end{array}$ \\
\hline Hong Kong & One large investment bank failed. & 1998 & $\begin{array}{l}\text { Caprio and Klingebiel } \\
(2003)\end{array}$ \\
\hline
\end{tabular}




\begin{tabular}{|c|c|c|c|}
\hline Country & Brief Summary & Year & Source \\
\hline Hungary & Run on Budapest banks; foreign withdrawals and bank holiday. & July, 1931 & $\begin{array}{l}\text { Bernanke and James } \\
(1990)\end{array}$ \\
\hline Hungary & $\begin{array}{l}\text { By second half of 1993, eight banks ( } 25 \% \text { of financial system assets) were } \\
\text { deemed insolvent. }\end{array}$ & 1991-1995 & $\begin{array}{l}\text { Caprio and Klingebiel } \\
(2003)\end{array}$ \\
\hline Iceland & One of three state-owned banks became insolvent. & $1985-1986$ & $\begin{array}{l}\text { Caprio and Klingebiel } \\
\text { (2003); Bordo et al. } \\
(2001)\end{array}$ \\
\hline Iceland & Government injected capital into state-owned commercial bank. & 1993 & $\begin{array}{l}\text { Caprio and Klingebiel } \\
\text { (2003); Bordo et al. } \\
\text { (2001) }\end{array}$ \\
\hline India & Central Bank of Western India went bankrupt in 1866. & 1863 & $\begin{array}{l}\text { Reinhart and Rogoff } \\
\text { (2008a) }\end{array}$ \\
\hline India & $\begin{array}{l}\text { Crop failures and excessive obligations to European banks; silver replaced } \\
\text { much of the gold. }\end{array}$ & April, 1908 & Conant (1915) \\
\hline India & Nonperforming assets of 27 public banks estimated at 20\% in 1995 . & $1993-1996$ & $\begin{array}{l}\text { Caprio and Klingebiel } \\
\text { (2003); Bordo et al. } \\
\text { (2001) }\end{array}$ \\
\hline Indonesia & $\begin{array}{l}\text { A large bank (Bank Summa) collapsed and triggered runs on three smaller } \\
\text { banks. }\end{array}$ & November, 1992 & $\begin{array}{l}\text { Kaminsky and Reinhart } \\
(1999)\end{array}$ \\
\hline Indonesia & $\begin{array}{l}\text { Nonperforming assets accounted for } 14 \% \text { of banking system assets with } \\
\text { more than } 70 \% \text { in state banks. }\end{array}$ & 1994 & $\begin{array}{l}\text { Caprio and Klingebiel } \\
\text { (2003); Bordo et al. } \\
\text { (2001) }\end{array}$ \\
\hline Indonesia & $\begin{array}{l}\text { Through May 2002, Bank Indonesia had closed } 70 \text { banks and nationalized } \\
13 \text { out of } 237 \text {. Nonperforming loans were } 65-75 \% \text { of total loans at the peak } \\
\text { of the crisis and fell to about } 12 \% \text { in February } 2002 \text {. }\end{array}$ & 1997-? & $\begin{array}{l}\text { Caprio and Klingebiel } \\
(2003)\end{array}$ \\
\hline Ireland & Run on most Irish banks; Agricultural Bank failed in November. & $\begin{array}{l}\text { November, } \\
1836-1837\end{array}$ & Conant (1915) \\
\hline Ireland & $\begin{array}{l}\text { Tipperary Joint Stock Bank failed upon discovery that one director (John } \\
\text { Sadlier) had systematically robbed the bank and falsified accounts. }\end{array}$ & February, 1856 & Conant (1915) \\
\hline Israel & $\begin{array}{l}\text { Almost the entire banking sector was affected, representing } 60 \% \text { of stock } \\
\text { market recapitalization. The stock exchange closed for } 18 \text { days and bank } \\
\text { share prices fell more than } 40 \% \text {. }\end{array}$ & $1977-1983$ & $\begin{array}{l}\text { Caprio and Klingebiel } \\
\text { (2003); Bordo et al. } \\
(2001)\end{array}$ \\
\hline Israel & Stocks of the four largest banks collapsed and were nationalized by the state. & October, 1983 & Reinhart (2002) \\
\hline Italy & $\begin{array}{l}\text { National Bank suspended specie due to expectation of the Austro-Prussian } \\
\text { War. }\end{array}$ & June, 1866-1868 & Conant (1915) \\
\hline Italy & $\begin{array}{l}\text { Tiber Bank, Italian Mortgage Bank Society and Naples Building Association } \\
\text { taken over by National Bank. }\end{array}$ & 1889 & Conant (1915) \\
\hline Italy & $\begin{array}{l}\text { Real estate boom and bust, bringing banks with it. Tariff war with France } \\
\text { raised interest rates and helped to prick the land bubble. Growth slowed and } \\
\text { did not pick up for five years. }\end{array}$ & 1891 & $\begin{array}{l}\text { Bordo and Eichengreen } \\
(1999)\end{array}$ \\
\hline Italy & $\begin{array}{l}\text { Government overhauled the banking system by merging several banks and } \\
\text { authorized expansions of credit, triggering a currency crisis. The lira } \\
\text { depreciated but the recessionary impact was mild. }\end{array}$ & January, 1893 & $\begin{array}{l}\text { Bordo and Eichengreen } \\
\text { (1999); Conant (1915) }\end{array}$ \\
\hline Italy & $\begin{array}{l}\text { Financial speculation and mounting difficulties in New York, London, and } \\
\text { Paris in } 1906 \text { put pressure on interest rates and pricked the financial bubble. } \\
\text { Sharp drop in output followed. }\end{array}$ & 1907 & $\begin{array}{l}\text { Bordo and Eichengreen } \\
\text { (1999) }\end{array}$ \\
\hline Italy & $\begin{array}{l}\text { Savings banks on the verge of collapse; rescued by the three main issuing } \\
\text { banks, which also supported industry during the war. }\end{array}$ & 1914 & $\begin{array}{l}\text { Bordo et al. (2001); } \\
\text { Teichova et al. (1997) }\end{array}$ \\
\hline Italy & $\begin{array}{l}\text { Third and fourth largest banks became insolvent, partly due to overtrading } \\
\text { during and after the war. }\end{array}$ & 1921 & Bordo et al. (2001) \\
\hline Italy & $\begin{array}{l}\text { Withdrawals from largest banks; panic ensued until April when government } \\
\text { reorganized many institutions and took over bad industrial assets. }\end{array}$ & $\begin{array}{l}\text { December } \\
1930-1931\end{array}$ & $\begin{array}{l}\text { Bordo et al. (2001); } \\
\text { Bernanke and James } \\
(1990)\end{array}$ \\
\hline Italy & $\begin{array}{l}\text { Agricultural bank closures, savings and commercial bank mergers to such an } \\
\text { extent that the Italian banking system appeared completely reorganized. }\end{array}$ & 1935 & $\begin{array}{l}\text { Bordo et al. (2001); } \\
\text { Teichova et al. (1997) }\end{array}$ \\
\hline
\end{tabular}




\begin{tabular}{|c|c|c|c|}
\hline Country & Brief Summary & Year & Source \\
\hline Italy & Fifty-eight banks, with $11 \%$ of lending, merged with other institutions. & $1990-1995$ & $\begin{array}{l}\text { Caprio and Klingebiel } \\
\text { (2003); Bordo et al. } \\
(2001)\end{array}$ \\
\hline Jamaica & A merchant banking group was closed. & $1994-1997$ & $\begin{array}{l}\text { Caprio and Klingebiel } \\
\text { (2003); Bordo et al. } \\
(2001)\end{array}$ \\
\hline Jamaica & $\begin{array}{l}\text { FINSAC, a government resolution agency, assisted five banks, five life } \\
\text { insurance companies, two building societies, and nine merchant banks. }\end{array}$ & $1995-2000$ & $\begin{array}{l}\text { Caprio and Klingebiel } \\
(2003)\end{array}$ \\
\hline Japan & $\begin{array}{l}\text { National Bank Act-banks forced to accept government's paper notes. } \\
\text { Caused nine or ten banks to fail. }\end{array}$ & $1872-1876$ & Conant (1915) \\
\hline Japan & $\begin{array}{l}\text { Deflationary measures depressed trade, and four national banks failed; five } \\
\text { suspended, } 10 \text { consolidated. }\end{array}$ & $1882-1885$ & Conant (1915) \\
\hline Japan & $\begin{array}{l}\text { Trade deficits and reserve losses; significant output losses_-growth fell by } \\
6 \% \text { in one year. }\end{array}$ & 1901 & $\begin{array}{l}\text { Bordo and Eichengreen } \\
\text { (1999) }\end{array}$ \\
\hline Japan & $\begin{array}{l}\text { Tokyo stock market crash in early } 1907 \text { and global uncertainty; Bank of } \\
\text { Japan intervened for some banks and let other banks fail. Recession was } \\
\text { severe. }\end{array}$ & 1907 & $\begin{array}{l}\text { Bordo and Eichengreen } \\
\text { (1999) }\end{array}$ \\
\hline Japan & Japan went off the gold standard; prospered from war boom. & 1917 & $\begin{array}{l}\text { Bordo et al. (2001); } \\
\text { Flath }\end{array}$ \\
\hline Japan & $\begin{array}{l}\text { Tokyo earthquake led to bad debts which shook the Bank of Tokyo and } \\
\text { Chosen. Restructured with government aid. }\end{array}$ & September, 1923 & $\begin{array}{l}\text { Bernanke and James } \\
(1990)\end{array}$ \\
\hline Japan & $\begin{array}{l}\text { Banking panic led to tighter regulation. Failure of Tokyo Watanabe bank led } \\
\text { to runs and a wave of failures-15 banks unable to make payments. } \\
\text { Government's unwillingness to bail out banks led to more uncertainty and } \\
\text { other runs. Crisis resulted in bank consolidations. }\end{array}$ & April, 1927 & $\begin{array}{l}\text { Bordo et al. (2001); } \\
\text { Bernanke and James } \\
(1990)\end{array}$ \\
\hline Japan & $\begin{array}{l}\text { Banks suffered from sharp decline in stock market and real estate prices. In } \\
1995 \text {, estimates of nonperforming loans were } \$ 469-1000 \text { billion or } 10-25 \% \\
\text { of GDP; at the end of } 1998 \text { they were estimated at } \$ 725 \text { billion or } 18 \% \text { of } \\
\text { GDP; and in } 2002 \text { were } 35 \% \text { of total loans. Seven banks were nationalized, } \\
61 \text { financial institutions closed, and } 28 \text { institutions merged. }\end{array}$ & $1992-1997$ & $\begin{array}{l}\text { Caprio and Klingebiel } \\
\text { (2003); Bordo et al. } \\
(2001)\end{array}$ \\
\hline Jordan & Third largest bank failed. & \begin{tabular}{|l|} 
August, \\
$1989-1990$ \\
\end{tabular} & $\begin{array}{l}\text { Caprio and Klingebiel } \\
(2003)\end{array}$ \\
\hline Kenya & $15 \%$ of financial system liabilities faced liquidity and solvency problems. & $1985-1989$ & $\begin{array}{l}\text { Caprio and Klingebiel } \\
(2003)\end{array}$ \\
\hline Kenya & Intervention in two local banks. & 1992 & $\begin{array}{l}\text { Caprio and Klingebiel } \\
(2003)\end{array}$ \\
\hline Kenya & $\begin{array}{l}\text { Serious solvency problems with banks accounting for more than } 30 \% \text { of } \\
\text { financial system assets. }\end{array}$ & $1993-1995$ & $\begin{array}{l}\text { Caprio and Klingebiel } \\
(2003)\end{array}$ \\
\hline Kenya & Nonperforming loans reached $19 \%$. & 1996 & $\begin{array}{l}\text { Caprio and Klingebiel } \\
(2003)\end{array}$ \\
\hline Korea & Financial deregulation led to an increase in the number of banks. & January, 1986 & $\begin{array}{l}\text { Reinhart (2002); Shin } \\
\text { and Hahm (1998) }\end{array}$ \\
\hline Korea & $\begin{array}{l}\text { Through May 2002, five banks were forced to exit the market through a } \\
\text { "purchase and assumption formula," and } 303 \text { financial institutions ( } 215 \text { were } \\
\text { credit unions) shut down, and four banks were nationalized. Banking system } \\
\text { nonperforming loans peaked between } 30-40 \% \text { and fell to about } 3 \% \text { by } \\
\text { March } 2002 \text {. }\end{array}$ & July, 1997 & $\begin{array}{l}\text { Reinhart (2002); Caprio } \\
\text { and Klingebiel (2003); } \\
\text { Bordo et al. (2001) }\end{array}$ \\
\hline Kuwait & About $40 \%$ of loans were nonperforming by 1986 . & $1980 \mathrm{~s}$ & $\begin{array}{l}\text { Caprio and Klingebiel } \\
(2003)\end{array}$ \\
\hline Kyrgyz Republic & $\begin{array}{l}\text { About } 80-90 \% \text { of banking system loans doubtful. Four small banks closed } \\
\text { in } 1995 .\end{array}$ & $1990 \mathrm{~s}$ & $\begin{array}{l}\text { Caprio and Klingebiel } \\
(2003)\end{array}$ \\
\hline $\begin{array}{l}\text { Lao People's Dem } \\
\text { Republic }\end{array}$ & Some banks experienced problems. & Early 1990s & $\begin{array}{l}\text { Caprio and Klingebiel } \\
(2003)\end{array}$ \\
\hline Latvia & Run on banks with German connections; two large banks hit especially hard. & July, 1931 & $\begin{array}{l}\text { Bernanke and James } \\
(1990)\end{array}$ \\
\hline
\end{tabular}




\begin{tabular}{|c|c|c|c|}
\hline Country & Brief Summary & Year & Source \\
\hline Latvia & $\begin{array}{l}\text { Between 1995-1999, } 35 \text { banks saw their license revoked, were closed, or } \\
\text { ceased operations. }\end{array}$ & 1995-? & $\begin{array}{l}\text { Caprio and Klingebiel } \\
(2003)\end{array}$ \\
\hline Lebanon & Four banks became insolvent and eleven resorted to Central Bank lending. & $1988-1990$ & $\begin{array}{l}\text { Caprio and Klingebiel } \\
(2003)\end{array}$ \\
\hline Lesotho & One of four commercial banks had nonperforming loans. & 1988 & $\begin{array}{l}\text { Caprio and Klingebiel } \\
(2003)\end{array}$ \\
\hline Liberia & 7/11 banks not operational, accounting for $60 \%$ of bank assets. & $1991-1995$ & $\begin{array}{l}\text { Caprio and Klingebiel } \\
\text { (2003) }\end{array}$ \\
\hline Lithuania & $\begin{array}{l}\text { In 1995, } 12 \text { small banks of } 25 \text { banks were liquidated; three private banks } \\
\text { ( } 29 \% \text { of banking system deposits) failed, and three state-owned banks were } \\
\text { deemed insolvent. }\end{array}$ & $1995-1996$ & $\begin{array}{l}\text { Caprio and Klingebiel } \\
(2003)\end{array}$ \\
\hline Macedonia & $\begin{array}{l}\text { About } 70 \% \text { of banking system loans were nonperforming. The government } \\
\text { took over banks' foreign debt and closed the second largest bank. }\end{array}$ & $1993-1994$ & $\begin{array}{l}\text { Caprio and Klingebiel } \\
(2003)\end{array}$ \\
\hline Madagascar & $25 \%$ of bank loans deemed unrecoverable. & 1988 & $\begin{array}{l}\text { Caprio and Klingebiel } \\
(2003)\end{array}$ \\
\hline Malaysia & $\begin{array}{l}\text { Runs against some branches of a large domestic bank, following the collapse } \\
\text { of a related bank in Hong Kong. Insolvent institutions accounted for } 3 \% \text { of } \\
\text { financial system deposits; marginally recapitalized and possibly insolvent } \\
\text { institutions accounted for another } 4 \% \text {. }\end{array}$ & July, 1985-1988 & $\begin{array}{l}\text { Kaminsky and Reinhart } \\
\text { (1999); Caprio and } \\
\text { Klingebiel (2003); Bordo } \\
\text { et al. (2001) }\end{array}$ \\
\hline Malaysia & $\begin{array}{l}\text { Finance company sector was restructured, and finance institutions reduced } \\
\text { from } 39 \text { to } 10 \text { through mergers. Two finance companies were taken over by } \\
\text { the Central Bank, including the largest independent finance company. Two } \\
\text { banks deemed insolvent-accounting for } 14 \% \text { of financial system } \\
\text { assets-will be merged with other banks. Nonperforming loans peaked } \\
\text { between } 25-35 \% \text { of banking system assets and fell to } 10.8 \% \text { by March } 2002 \text {. }\end{array}$ & September, 1997 & $\begin{array}{l}\text { Reinhart (2002); Caprio } \\
\text { and Klingebiel (2003); } \\
\text { Bordo et al. (2001) }\end{array}$ \\
\hline Mali & Nonperforming loans of largest bank reached 75\%. & $1987-1989$ & $\begin{array}{l}\text { Caprio and Klingebiel } \\
(2003)\end{array}$ \\
\hline Mauritania & $\begin{array}{l}\text { In 1984, five major banks had nonperforming assets from } 45-70 \% \text { of their } \\
\text { portfolios. }\end{array}$ & $1984-1993$ & $\begin{array}{l}\text { Caprio and Klingebiel } \\
(2003)\end{array}$ \\
\hline Mauritius & Central Bank closed 2/12 commercial banks for fraud and irregularities. & 1996 & $\begin{array}{l}\text { Caprio and Klingebiel } \\
(2003)\end{array}$ \\
\hline Mexico & $\begin{array}{l}\text { Mexican government borrowed widely and then suspended payments (June } \\
\text { 1885); foreign investments fell leading to a credit crisis, bank runs, and } \\
\text { banks stopped lending. National Bank and Mercantile Bank merged into } \\
\text { National Bank of Mexico (Banamex) in } 1884 \text { to meet government's demand } \\
\text { for a loan. }\end{array}$ & $\begin{array}{l}\text { February, } \\
1884-1885\end{array}$ & Conant (1915) \\
\hline Mexico & National Bank absorbed Mexican Mercantile Bank, its main competitor. & 1893 & Conant (1915) \\
\hline Mexico & $\begin{array}{l}\text { Severe credit shortage from U.S. crash; banks could not collect debts; } \\
\text { Mexican Central Bank and many state banks failed. Other banks survived } \\
\text { with federal assistance or by merging. Failures caused many bankruptcies } \\
\text { and prevented economic activity. Government cautioned against over- } \\
\text { expansion of credit-first a circular (Feb.) warned against unsafe loans; } \\
\text { restrictions imposed in June. }\end{array}$ & February, 1908 & Conant (1915) \\
\hline Mexico & Suspension of payments after a run on major banks. & July, 1931 & $\begin{array}{l}\text { Bernanke and James } \\
(1990)\end{array}$ \\
\hline Mexico & $\begin{array}{l}\text { Capital flight; government responded by nationalizing the private banking } \\
\text { system. }\end{array}$ & $1981-1982$ & Bordo et al. (2001) \\
\hline Mexico & Government took over banking system. & $\begin{array}{l}\text { September, } \\
1982-1991\end{array}$ & $\begin{array}{l}\text { Kaminsky and Reinhart } \\
\text { (1999) \& Caprio and } \\
\text { Klingebiel (2003) }\end{array}$ \\
\hline Mexico & $\begin{array}{l}\text { Several financial institutions that held Ajustabonos were hurt by the rise in } \\
\text { real interest rates in the second half of } 1992 .\end{array}$ & October, 1992 & $\begin{array}{l}\text { Kaminsky and Reinhart } \\
\text { (1999) }\end{array}$ \\
\hline
\end{tabular}




\begin{tabular}{|c|c|c|c|}
\hline Country & Brief Summary & Year & Source \\
\hline Mexico & $\begin{array}{l}\text { In 1994, nine banks were intervened and } 11 \text { participated in the loan/purchase } \\
\text { recapitalization program of } 34 \text { commercial banks. The nine banks accounted } \\
\text { for } 19 \% \text { of financial system assets and were deemed insolvent. } 1 \% \text { of bank } \\
\text { assets were owned by foreigner, and by } 1998,18 \% \text { of bank assets were held } \\
\text { by foreign banks. }\end{array}$ & $1994-1997$ & $\begin{array}{l}\text { Caprio and Klingebiel } \\
\text { (2003); Bordo et al. } \\
\text { (2001); Jácome (2008) }\end{array}$ \\
\hline Morocco & Banking sector experienced problems. & Early 1980s & $\begin{array}{l}\text { Caprio and Klingebiel } \\
(2003)\end{array}$ \\
\hline Mozambique & $\begin{array}{l}\text { Main commercial bank experienced solvency problems_-apparent after } \\
1992 .\end{array}$ & 1987-1995 & $\begin{array}{l}\text { Caprio and Klingebiel } \\
(2003)\end{array}$ \\
\hline Myanmar & $\begin{array}{l}\text { Largest state-owned commercial bank reported to have large nonperforming } \\
\text { loans. }\end{array}$ & $1996-?$ & $\begin{array}{l}\text { Caprio and Klingebiel } \\
(2003)\end{array}$ \\
\hline Nepal & $\begin{array}{l}\text { In early 1988, the reported arrears of three banks, accounting for } 95 \% \text { of the } \\
\text { financial system, averaged } 29 \% \text { of assets. }\end{array}$ & 1988 & $\begin{array}{l}\text { Caprio and Klingebiel } \\
(2003)\end{array}$ \\
\hline Netherlands & $\begin{array}{l}\text { Bank of Amsterdam closed by government decree; liquidation began in } \\
\text { January and lasted a long time. }\end{array}$ & $\begin{array}{l}\text { December, } \\
1819-1829 \\
\end{array}$ & Conant (1915) \\
\hline Netherlands & & 1897 & Bordo et al. (2001) \\
\hline Netherlands & $\begin{array}{l}\text { Temporary closure of the Amsterdam Exchange led to a sharp acceleration } \\
\text { in the evolution of banking. Large commercial banks replaced older } \\
\text { institutions, and many banks were taken over or replaced. }\end{array}$ & 1914 & $\begin{array}{l}\text { Bordo et al. (2001); } \\
\text { 'tHart et al. (1997) }\end{array}$ \\
\hline Netherlands & $\begin{array}{l}\text { Scores of banks failed and many others experienced serious problems. } \\
\text { Banking crisis resulted in banks working more closely together and were } \\
\text { characterized by more centralization. Banks financed industry more heavily } \\
\text { after the war; after the crisis, industrial growth stalled. }\end{array}$ & 1921 & $\begin{array}{l}\text { Bordo et al. (2001); } \\
\text { 'tHart et al. (1997) }\end{array}$ \\
\hline Netherlands & & 1939 & Bordo et al. (2001) \\
\hline New Zealand & $\begin{array}{l}\text { One large state-owned bank, with } 25 \% \text { of banking assets, experienced } \\
\text { solvency problems with high nonperforming loans. }\end{array}$ & 1987-1990 & $\begin{array}{l}\text { Caprio and Klingebiel } \\
\text { (2003); Bordo et al. } \\
(2001)\end{array}$ \\
\hline Nicaragua & Banking system nonperforming loans reached 50\% in 1996. & Late 1980s-96 & $\begin{array}{l}\text { Caprio and Klingebiel } \\
(2003)\end{array}$ \\
\hline Nicaragua & $\begin{array}{l}\text { Four out } 11 \text { banks, representing about } 40 \% \text { of deposits, were intervened and } \\
\text { sold to other financial institutions. }\end{array}$ & 2001-2002 & Jácome (2008) \\
\hline Niger & $\begin{array}{l}\text { Mid-1980s, banking system nonperforming loans reached 50\%. Four banks } \\
\text { liquidated, three restructured in the late 80s; more restructuring in } 2002 .\end{array}$ & 1983-? & $\begin{array}{l}\text { Caprio and Klingebiel } \\
(2003)\end{array}$ \\
\hline Nigeria & $\begin{array}{l}\text { In 1993, insolvent banks had } 20 \% \text { of banking system assets and } 22 \% \text { of } \\
\text { deposits. In 1995, almost half the banks reported being in financial distress. }\end{array}$ & 1991-1995 & $\begin{array}{l}\text { Bordo et al. (2001); } \\
\text { Caprio and Klingebiel } \\
(2003)\end{array}$ \\
\hline Nigeria & Distressed banks had $4 \%$ of banking system assets. & 1997 & $\begin{array}{l}\text { Caprio and Klingebiel } \\
\text { (2003); Bordo et al. }\end{array}$ \\
\hline Norway & $\begin{array}{l}\text { Real estate speculation; bubble burst when interest rates increased, and many } \\
\text { banks failed. Bank of Norway stepped in and prevented spreading crisis. }\end{array}$ & May, 1899 & $\begin{array}{l}\text { Jonung and Hagberg } \\
(2002)\end{array}$ \\
\hline Norway & $\begin{array}{l}\text { Due to reckless lending during the war and the global downswing in the } \\
\text { early } 1920 \text { s. }\end{array}$ & $1921-1923$ & $\begin{array}{l}\text { Bordo et al. (2001); } \\
\text { Jonung and Hagberg } \\
(2002)\end{array}$ \\
\hline Norway & $\begin{array}{l}\text { Norway abandoned the gold standard; the Norges Bank provided much } \\
\text { support to smaller banks to prevent a systemic crisis. More successfully } \\
\text { managed than the } 1921 \text { crisis. }\end{array}$ & 1931 & $\begin{array}{l}\text { Bordo et al. (2001); } \\
\text { Øksendal (2007) }\end{array}$ \\
\hline Norway & Legislation introducing a tax on bank deposits led to many withdrawals. & 1936 & $\begin{array}{l}\text { Bernanke and James } \\
(1990)\end{array}$ \\
\hline Norway & $\begin{array}{l}\text { Two regional saving banks failed. The banks were eventually merged and } \\
\text { bailed out. The Central Bank provided special loans to six banks suffering } \\
\text { from the recession of } 1985-86 \text { and from problem real estate loans. The state } \\
\text { took control of the three largest banks with } 85 \% \text { of banking system assets. }\end{array}$ & $\begin{array}{l}\text { November, } \\
1988-1993\end{array}$ & $\begin{array}{l}\text { Kaminsky and Reinhart } \\
\text { (1999); Caprio and } \\
\text { Klingebiel (2003); Bordo } \\
\text { et al. (2001); Jonung and } \\
\text { Hagberg (2002) }\end{array}$ \\
\hline
\end{tabular}




\begin{tabular}{|c|c|c|c|}
\hline Country & Brief Summary & Year & Source \\
\hline Panama & $\begin{array}{l}\text { In 1988, the banking system had a nine-week banking holiday. The financial } \\
\text { position of most state-owned and private commercial banks was weak and } \\
15 \text { banks ceased operations. }\end{array}$ & $1988-1989$ & $\begin{array}{l}\text { Caprio and Klingebiel } \\
(2003)\end{array}$ \\
\hline Papua New Guinea & $85 \%$ of S\&L associations ceased operations. & 1989-? & $\begin{array}{l}\text { Caprio and Klingebiel } \\
(2003)\end{array}$ \\
\hline Paraguay & $\begin{array}{l}\text { Bank of Paraguay and River Plate Bank suspended payments; subject to } \\
\text { severe run-gold prices increased 300\% and banks eventually liquidated. }\end{array}$ & 1890 & Conant (1915) \\
\hline Paraguay & $\begin{array}{l}\text { The Government Superintendency intervened in most domestic private and } \\
\text { public banks and a number of finance companies by the end of } 1998 \text {, } \\
\text { including the largest bank and savings \& loan institution. By the end of } \\
\text { 1999, banks were mostly foreign-owned, with over } 80 \% \text { of bank assets in } \\
\text { foreign hands. All banks were deemed sound in } 2000 \text {. }\end{array}$ & $1995-1999$ & $\begin{array}{l}\text { Caprio and Klingebiel } \\
\text { (2003); Bordo et al. } \\
\text { (2001); Jácome (2008) }\end{array}$ \\
\hline Paraguay & $\begin{array}{l}\text { Two banks, with about 10\% of deposits, were intervened and closed in } 1997 . \\
\text { A medium-sized bank, with 6.5\% of deposits, was closed in } 1998 .\end{array}$ & 1997-1998 & Jácome (2008) \\
\hline Paraguay & $\begin{array}{l}\text { The third largest bank, with nearly } 10 \% \text { of deposits, was intervened and } \\
\text { closed. }\end{array}$ & $2001-2002$ & $\begin{array}{l}\text { Caprio and Klingebiel } \\
\text { (2003); Jácome (2008) }\end{array}$ \\
\hline Peru & Gold coinage suspended and country on silver standard for 25 years. & $\begin{array}{l}\text { December, } \\
1872-1873\end{array}$ & $\begin{array}{l}\text { Conant (1915); Reinhart } \\
\text { and Rogoff (2008a) }\end{array}$ \\
\hline Peru & $\begin{array}{l}\text { Two large banks failed. The rest of the system suffered from high } \\
\text { nonperforming loans and financial disintermediation following the } \\
\text { nationalization of the banking system in } 1987 .\end{array}$ & April, 1983-1990 & $\begin{array}{l}\text { Kaminsky and Reinhart } \\
\text { (1999); Caprio and } \\
\text { Klingebiel (2003); Bordo } \\
\text { et al. (2001) }\end{array}$ \\
\hline Peru & $\begin{array}{l}\text { Capital outflows triggered a domestic credit crunch, which unveiled } \\
\text { solvency problems in a number of banks, including Banco Wiese, Banco } \\
\text { Latino ( } 16.7 \% \text { and } 3 \% \text { market share, respectively), and other smaller } \\
\text { financial institutions. Bank resolution was applied to two banks (summing } \\
\text { nearly } 21 \% \text { of deposits). Instability also affected another six small banks } \\
\text { (6.5\% of deposits). }\end{array}$ & 1999 & Jácome (2008) \\
\hline Philippines & $\begin{array}{l}\text { Commercial paper market collapsed, triggering bank runs and failure of } \\
\text { nonbank financial institutions and thrift banks. Problems in two public banks } \\
\text { accounting for } 50 \% \text { of banking system assets, six private banks accounting } \\
\text { for } 12 \% \text { of banking system assets, } 32 \text { thrifts accounting for } 53 \% \text { of thrift } \\
\text { banking assets, and } 128 \text { rural banks. }\end{array}$ & $\begin{array}{l}\text { January, } \\
1981-1987\end{array}$ & $\begin{array}{l}\text { Kaminsky and Reinhart } \\
\text { (1999); Caprio and } \\
\text { Klingebiel (2003); Bordo } \\
\text { et al. (2001) }\end{array}$ \\
\hline Philippines & $\begin{array}{l}\text { One commercial bank, seven of } 88 \text { thrifts, and } 40 \text { of } 750 \text { rural banks placed } \\
\text { under receivership. Banking system nonperforming loans reached } 12 \% \text { by } \\
\text { November } 1998 \text { and were expected to reach } 20 \% \text { in } 1999 \text {. }\end{array}$ & July, 1997-1998 & $\begin{array}{l}\text { Reinhart (2002); Caprio } \\
\text { and Klingebiel (2003) }\end{array}$ \\
\hline Poland & $\begin{array}{l}\text { Bank runs caused three large banks to stop payments; bank shakeout lasted } \\
\text { until } 1927 .\end{array}$ & July 1926-1927 & $\begin{array}{l}\text { Bernanke and James } \\
(1990)\end{array}$ \\
\hline Poland & $\begin{array}{l}\text { Run on banks, especially those associated with Austrian } \\
\text { Creditanstalt—-spread of Austrian crisis. }\end{array}$ & June, 1931 & $\begin{array}{l}\text { Bernanke and James } \\
(1990)\end{array}$ \\
\hline Poland & $\begin{array}{l}\text { In 1991, seven of nine treasury-owned commercial banks ( } 90 \% \text { of credit), } \\
\text { the Bank for Food Economy, and the cooperative banking system } \\
\text { experienced solvency problems. }\end{array}$ & 1990s & $\begin{array}{l}\text { Caprio and Klingebiel } \\
(2003)\end{array}$ \\
\hline Portugal & $\begin{array}{l}\text { Bank of Lisbon suspended payments-consistently troubled career because } \\
\text { tied with Portuguese government. }\end{array}$ & 1828 & Conant (1915) \\
\hline Portugal & $\begin{array}{l}\text { Bank of Lisbon lost all credit, could not redeem notes, reorganized into the } \\
\text { Bank of Portugal. }\end{array}$ & May, 1846-1847 & Conant (1915) \\
\hline Portugal & $\begin{array}{l}\text { Large budget deficits, the Baring crisis, and the Brazilian revolution led to } \\
\text { currency depreciation. Reneged on some domestic debt and renegotiated } \\
\text { foreign debt to reduce interest payments. Large impact on growth. }\end{array}$ & 1891 & $\begin{array}{l}\text { Bordo and Eichengreen } \\
\text { (1999); Conant (1915) }\end{array}$ \\
\hline Portugal & & 1920 & Bordo et al. (2001) \\
\hline Portugal & & 1923 & Bordo et al. (2001) \\
\hline Portugal & & 1931-1932 & Bordo et al. (2001) \\
\hline Romania & Collapse of German-controlled banks and other banks; heavy runs on banks. & July, 1931 & $\begin{array}{l}\text { Bernanke and James } \\
(1990)\end{array}$ \\
\hline
\end{tabular}




\begin{tabular}{|c|c|c|c|}
\hline Country & Brief Summary & Year & Source \\
\hline Romania & $\begin{array}{l}\text { In 1998, nonperforming loans reached } 25-30 \% \text { in the six main state-owned } \\
\text { banks. }\end{array}$ & 1990 & $\begin{array}{l}\text { Caprio and Klingebiel } \\
(2003)\end{array}$ \\
\hline Russia & $\begin{array}{l}\text { Bank of Russia closed in April; specie payments suspended and never } \\
\text { resumed. A permanent treasury deficit meant several loans were necessary } \\
\text { and there was a hopeless credit situation. }\end{array}$ & April, 1862-1863 & Conant (1915) \\
\hline Russia & $\begin{array}{l}\text { Skopine community bank garnered deposits from all over the empire but } \\
\text { kept low reserves; bubble burst in } 1875 \text { when it could not pay its deposits; } \\
\text { limited communal banking henceforth. }\end{array}$ & 1875 & $\begin{array}{l}\text { Reinhart and Rogoff } \\
\text { (2008a); Conant (1915) }\end{array}$ \\
\hline Russia & $\begin{array}{l}\text { Joint-Stock commercial banks loaded with nonperforming assets; many } \\
\text { small banks failed although large ones were protected by the state bank. }\end{array}$ & 1896 & Cameron (1967) \\
\hline Russia & $\begin{array}{l}\text { The interbank loan market stopped working due to concerns about } \\
\text { connected lending in many new banks. }\end{array}$ & August, 1995 & $\begin{array}{l}\text { Caprio and Klingebiel } \\
(2003)\end{array}$ \\
\hline Russia & $\begin{array}{l}\text { Nearly } 720 \text { banks, representing half of those in operation, were deemed } \\
\text { insolvent. The banks accounted for } 4 \% \text { of sector assets and } 32 \% \text { of retail } \\
\text { deposits. Eighteen banks, holding } 40 \% \text { of sector assets and } 41 \% \text { of } \\
\text { household deposits, were in serious difficulties and needed rescue. }\end{array}$ & 1998-1999 & $\begin{array}{l}\text { Caprio and Klingebiel } \\
(2003)\end{array}$ \\
\hline Rwanda & One well-connected bank closed. & 1991 & $\begin{array}{l}\text { Caprio and Klingebiel } \\
(2003)\end{array}$ \\
\hline Santo Domingo & $\begin{array}{l}\text { National Bank failed after unsuccessfully trying to adopt the gold standard; } \\
\text { bank notes not accepted anywhere. }\end{array}$ & 1894 & Conant (1915) \\
\hline $\begin{array}{l}\text { Sao Tome and } \\
\text { Principe }\end{array}$ & $\begin{array}{l}\text { End of 1992, 90\% of monobank's loans were nonperforming. In 1993, } \\
\text { monobank liquidated and two new banks were licensed and took over most } \\
\text { assets. In 1994, credit operations at one new bank suspended. }\end{array}$ & 1980s-90s & $\begin{array}{l}\text { Caprio and Klingebiel } \\
(2003)\end{array}$ \\
\hline Scotland & $\begin{array}{l}\text { Western Bank Failure-brought on by reckless banking practices; bank } \\
\text { made various bad loans to four firms-when discovered, the accounts were } \\
\text { stopped and firms closed. There was a panic on the stock exchange; } \\
\text { depositors withdraw their accounts and bank failed. }\end{array}$ & $\begin{array}{l}\text { October, } \\
1857-1858\end{array}$ & Conant (1915) \\
\hline Scotland & $\begin{array}{l}\text { City of Glasgow Bank failure: falsification of books for three years, with } \\
\text { loans to four firms; ruined shareholders, not creditors. }\end{array}$ & $\begin{array}{l}\text { September, } \\
1878-1880\end{array}$ & Conant (1915) \\
\hline Scotland & $\begin{array}{l}\text { Bank of Scotland absorbed Caledonian Bank, and North of Scotland Bank } \\
\text { absorbed Town \& Country Bank. }\end{array}$ & March, 1908 & Conant (1915) \\
\hline Senegal & $\begin{array}{l}\text { In 1988, 50\% of loans were nonperforming. Six commercial banks and one } \\
\text { development bank closed (20-30\% of financial system assets). }\end{array}$ & $1988-1991$ & $\begin{array}{l}\text { Caprio and Klingebiel } \\
(2003) \text {; Bordo et al. }\end{array}$ \\
\hline Sierra Leone & $\begin{array}{l}\text { In 1995, 40-50\% of banking system loans were } \\
\text { nonperforming- undergoing bank recapitalization and restructuring. }\end{array}$ & 1990 & $\begin{array}{l}\text { Caprio and Klingebiel } \\
(2003)\end{array}$ \\
\hline Singapore & Nonperforming loans rose to $\$ 200$ million or $0.6 \%$ of GDP. & 1982 & $\begin{array}{l}\text { Caprio and Klingebiel } \\
(2003) \text {; Bordo et al. }\end{array}$ \\
\hline Slovakia & $\begin{array}{l}\text { In } 1997 \text {, unrecoverable loans were estimated at } 101 \text { billion crowns-about } \\
31 \% \text { of loans and } 15 \% \text { of GDP. }\end{array}$ & 1991 & $\begin{array}{l}\text { Caprio and Klingebiel } \\
(2003)\end{array}$ \\
\hline Slovenia & Three banks (2/3 of banking system assets) were restructured. & $1992-1994$ & $\begin{array}{l}\text { Caprio and Klingebiel } \\
(2003)\end{array}$ \\
\hline South Africa & Trust Bank experienced problems. & $\begin{array}{l}\text { December, } \\
1977-1978\end{array}$ & $\begin{array}{l}\text { Caprio and Klingebiel } \\
\text { (2003); Reinhart (2002); } \\
\text { Bordo et al. (2001) }\end{array}$ \\
\hline South Africa & Some banks experienced problems. & 1989 & $\begin{array}{l}\text { Caprio and Klingebiel } \\
(2003)\end{array}$ \\
\hline Spain & $\begin{array}{l}\text { During the Peninsular War, Spain was occupied by France, and Bank of St. } \\
\text { Charles essentially dead since 1814; reorganized into Bank of St. Ferdinand } \\
\text { in } 1829 .\end{array}$ & $1814-1817$ & Conant (1915) \\
\hline Spain & Bank of St. Charles reorganized into Bank of Ferdinand. & July, 1829 & Conant (1915) \\
\hline
\end{tabular}




\begin{tabular}{|c|c|c|c|}
\hline Country & Brief Summary & Year & Source \\
\hline Spain & $\begin{array}{l}\text { Bank of Isabella II (created by government to punish Bank of Ferdinand in } \\
\text { 1844) and Bank of Ferdinand consolidated into one, Bank of Ferdinand. } \\
\text { Ferdinand bore Isabella's debts and was completely at the mercy of the State. } \\
\text { In 1848, cash reserve of Bank decreasing, circulation increasing, } \\
\text { government demanded more loans, victim of theft and embezzlement. } \\
\text { Government reorganized the bank into Bank of Spain to resemble Bank of } \\
\text { England. }\end{array}$ & $\begin{array}{l}\text { February } \\
1846-1847 \\
\end{array}$ & Conant (1915) \\
\hline Spain & & 1920-1923 & Bordo \\
\hline Spain & Failure of two major banks. & $1924-1925$ & $\begin{array}{l}\text { Bordo et al. (2001); } \\
\text { Bernanke and James } \\
(1990)\end{array}$ \\
\hline Spain & $\begin{array}{l}\text { Avoided the worst of the Great Depression by staying off the gold standard; } \\
\text { experienced runs, but Bank of Spain could lend freely as a lender of last } \\
\text { resort. }\end{array}$ & 1931 & $\begin{array}{l}\text { Bordo et al. (2001); } \\
\text { Temin (2008) }\end{array}$ \\
\hline Spain & $\begin{array}{l}\text { Bank of Spain began rescuing a number of smaller banks. In 1978-83, } 24 \\
\text { institutions were rescued, four were liquidated, four were merged, and } 20 \\
\text { small and medium-sized banks were nationalized. These } 52 \text { banks of } 110 \text {, } \\
\text { representing } 20 \% \text { of banking system deposits, were experiencing solvency } \\
\text { problems. }\end{array}$ & $\begin{array}{l}\text { November, } \\
1978-1985\end{array}$ & $\begin{array}{l}\text { Kaminsky and Reinhart } \\
\text { (1999); Caprio and } \\
\text { Klingebiel (2003); Bordo } \\
\text { et al. (2001) }\end{array}$ \\
\hline Sri Lanka & $\begin{array}{l}\text { State-owned banks, comprising } 70 \% \text { of the banking system, estimated to } \\
\text { have nonperforming loans of } 35 \% \text {. }\end{array}$ & $1989-1993$ & $\begin{array}{l}\text { Caprio and Klingebiel } \\
(2003)\end{array}$ \\
\hline Swaziland & Central Bank took over three other banks. & & $\begin{array}{l}\text { Caprio and Klingebiel } \\
(2003)\end{array}$ \\
\hline Sweden & $\begin{array}{l}\text { Depreciation of gold led to Bullion Report (similar to Report on Irish } \\
\text { Currency in 1804). }\end{array}$ & January, 1811 & Conant (1915) \\
\hline Sweden & Severe banking crises. & 1876-1879 & $\begin{array}{l}\text { Jonung and Hagberg } \\
(2002)\end{array}$ \\
\hline Sweden & Jonung and Hagberg do not record a crisis. & 1897 & $\begin{array}{l}\text { Bordo et al. (2001); } \\
\text { Jonung and Hagberg } \\
(2002)\end{array}$ \\
\hline Sweden & $\begin{array}{l}\text { Lending boom and decreasing confidence in stability of banking system led } \\
\text { to bank runs. Reserves depreciated but Riksbank extended loans to national } \\
\text { banks. Output negatively affected, but the economy recovered quickly. }\end{array}$ & 1907 & $\begin{array}{l}\text { Bordo and Eichengreen } \\
\text { (1999); Jonung and } \\
\text { Hagberg (2002) }\end{array}$ \\
\hline Sweden & $\begin{array}{l}\text { One of severest banking crises in Swedish banking history; followed a steep } \\
\text { recession. }\end{array}$ & $1922-1923$ & $\begin{array}{l}\text { Jonung and Hagberg } \\
(2002)\end{array}$ \\
\hline Sweden & $\begin{array}{l}\text { Banks tied to the financier Ivar Kreuger suffered after his death; banks } \\
\text { suffered large losses, but depositors were protected by the government and } \\
\text { did not suffer from the failures. }\end{array}$ & $1931-1932$ & $\begin{array}{l}\text { Bordo et al. (2001); } \\
\text { Jonung and Hagberg } \\
(2002)\end{array}$ \\
\hline Sweden & $\begin{array}{l}\text { Swedish government rescued Nordbanken, the second largest bank. } \\
\text { Nordbanken and Gota Bank, with } 22 \% \text { of banking system assets, were } \\
\text { insolvent. Sparbanken Foresta, accounting for } 24 \% \text { of banking system assets, } \\
\text { intervened. Five of the six largest banks, accounting for over } 70 \% \text { of } \\
\text { banking system assets, experienced difficulties. }\end{array}$ & $\begin{array}{l}\text { November, } \\
1991-1994\end{array}$ & $\begin{array}{l}\text { Kaminsky and Reinhart } \\
\text { (1999); Caprio and } \\
\text { Klingebiel (2003); Bordo } \\
\text { et al. (2001); Jonung and } \\
\text { Hagberg (2002) }\end{array}$ \\
\hline Switzerland & $\begin{array}{l}\text { Switzerland could not obtain its supply of coin from France; bank clients } \\
\text { rushed to redeem their notes for coin; bank cut down discounts and loans, } \\
\text { led to an economic downturn. }\end{array}$ & July, $1870-1871$ & Conant (1915) \\
\hline Switzerland & Wave of bank failures and consolidations. & $1910-1913$ & Vogler (2001) \\
\hline Switzerland & $\begin{array}{l}\text { Swiss banks badly shaken by German banking crisis; total assets shrank and } \\
\text { many banks restructured. }\end{array}$ & 1931 & $\begin{array}{l}\text { Bordo et al. (2001); } \\
\text { Vogler (2001) }\end{array}$ \\
\hline Switzerland & $\begin{array}{l}\text { Continued distress due to pressures from America and the Great Depression } \\
\text { and the German banking crisis of } 1931 \text {. }\end{array}$ & 1933 & $\begin{array}{l}\text { Bordo et al. (2001); } \\
\text { Vogler (2001) }\end{array}$ \\
\hline Taiwan & Four trust companies and eleven corporations failed. & $1983-1984$ & $\begin{array}{l}\text { Caprio and Klingebiel } \\
\text { (2003); Bordo et al. } \\
(2001)\end{array}$ \\
\hline
\end{tabular}




\begin{tabular}{|c|c|c|c|}
\hline Country & Brief Summary & Year & Source \\
\hline Taiwan & Failure of Changua Fourth sparked runs on other credit unions. & July, 1995 & $\begin{array}{l}\text { Caprio and Klingebiel } \\
\text { (2003); Bordo et al. } \\
(2001)\end{array}$ \\
\hline Taiwan & Banking system nonperforming loans estimated at $15 \%$ at the end of 1998. & $1997-1998$ & $\begin{array}{l}\text { Caprio and Klingebiel } \\
\text { (2003); Bordo et al. } \\
(2001)\end{array}$ \\
\hline Tajikistan & One of largest banks insolvent, one small bank closed. & $1996-$ & $\begin{array}{l}\text { Caprio and Klingebiel } \\
(2003)\end{array}$ \\
\hline Tanzania & $\begin{array}{l}\text { In 1987, main financial institutions had arrears amounting to half their } \\
\text { portfolios. National Bank of Commerce, with 95\% of banking system assets, } \\
\text { became insolvent in } 1990 .\end{array}$ & late 1980s-90s & $\begin{array}{l}\text { Caprio and Klingebiel } \\
(2003)\end{array}$ \\
\hline Thailand & $\begin{array}{l}\text { Following the stock market crash, one of the largest finance companies } \\
\text { failed. The bailout of the financial sector began. }\end{array}$ & March, 1979 & $\begin{array}{l}\text { Kaminsky and Reinhart } \\
(1999)\end{array}$ \\
\hline Thailand & $\begin{array}{l}\text { Large losses in a finance company led to runs and government intervention. } \\
\text { Authorities intervene in } 50 \text { finance and security firms and five commercial } \\
\text { banks, or about } 25 \% \text { of financial system assets; three commercial banks } \\
\text { deemed insolvent ( } 14 \% \text { of commercial bank assets). }\end{array}$ & $\begin{array}{l}\text { October, } \\
1983-1987\end{array}$ & $\begin{array}{l}\text { Kaminsky and Reinhart } \\
\text { (1999); Caprio and } \\
\text { Klingebiel (2003); Bordo } \\
\text { et al. (2001) }\end{array}$ \\
\hline Thailand & $\begin{array}{l}\text { As of May 2002, the Bank of Thailand shut down } 59 \text { of } 91 \text { financial } \\
\text { companies (13\% of financial system assets and } 72 \% \text { of finance company } \\
\text { assets), one of } 15 \text { domestic banks, and nationalized four banks. A publicly } \\
\text { owned assets management company held } 29.7 \% \text { of financial system assets as } \\
\text { of March } 2002 \text {. Nonperforming loans peaked at } 33 \% \text { of total loans and were } \\
\text { reduced to } 10.3 \% \text { of total loans in February } 2002 \text {. }\end{array}$ & May, 1996 & $\begin{array}{l}\text { Reinhart (2002); Caprio } \\
\text { and Klingebiel (2003); } \\
\text { Bordo et al. (2001) }\end{array}$ \\
\hline Togo & Banking sector experienced solvency problems. & $1993-1995$ & $\begin{array}{l}\text { Caprio and Klingebiel } \\
(2003)\end{array}$ \\
\hline Trinidad \& Tobago & $\begin{array}{l}\text { Several financial institutions faced solvency problems and three government- } \\
\text { owned banks merged. }\end{array}$ & $1982-1993$ & $\begin{array}{l}\text { Caprio and Klingebiel } \\
(2003)\end{array}$ \\
\hline Tunisia & Most commercial banks were undercapitalized. & $1991-1995$ & $\begin{array}{l}\text { Caprio and Klingebiel } \\
(2003)\end{array}$ \\
\hline Turkey & Runs on branches of German banks in wake of German crisis. & July, 1931 & $\begin{array}{l}\text { Bernanke and James } \\
(1990)\end{array}$ \\
\hline Turkey & $\begin{array}{l}\text { Start of the war led to massive withdrawals and a run on banks, prompting } \\
\text { the government to guarantee all deposits. }\end{array}$ & January, 1991 & $\begin{array}{l}\text { Kaminsky and Reinhart } \\
\text { (1999) }\end{array}$ \\
\hline Turkey & $\begin{array}{l}\text { Three banks were merged with the state-owned Agriculture Bank and then } \\
\text { liquidated; two large banks were restructured. }\end{array}$ & $1982-1985$ & $\begin{array}{l}\text { Caprio and Klingebiel } \\
\text { (2003); Bordo et al. } \\
(2001)\end{array}$ \\
\hline Turkey & Three banks failed in April 1994. & April, 1994 & $\begin{array}{l}\text { Caprio and Klingebiel } \\
\text { (2003); Bordo et al. } \\
(2001)\end{array}$ \\
\hline Turkey & $\begin{array}{l}\text { Two banks closed and } 19 \text { banks have been taken over by the Savings } \\
\text { Deposit Insurance Fund. }\end{array}$ & 2000 & $\begin{array}{l}\text { Caprio and Klingebiel } \\
(2003)\end{array}$ \\
\hline Uganda & $\begin{array}{l}\text { During 1994-98: half the banking system faced solvency problems. During } \\
\text { 1998-2002: various banks recapitalized and privatized or closed. }\end{array}$ & 1994 & $\begin{array}{l}\text { Caprio and Klingebiel } \\
(2003)\end{array}$ \\
\hline Ukraine & $\begin{array}{l}\text { By 1997, } 32 \text { of } 195 \text { banks were being liquidated while } 25 \text { others were } \\
\text { undergoing financial rehabilitation. Bad loans amounted to 50-65\% of } \\
\text { assets, even in some leading banks. In 1998, banks were further hit by the } \\
\text { government's decision to restructure its debt. }\end{array}$ & $1997-1998$ & $\begin{array}{l}\text { Caprio and Klingebiel } \\
(2003)\end{array}$ \\
\hline United Kingdom & $\begin{array}{l}\text { Mass speculation due to Napoleon’s Berlin Decree-many new country } \\
\text { banks issued notes; excessive issue led to severe fall in London exchange; } \\
\text { Treasury rescued banks on April 11, } 1811 .\end{array}$ & January, 1811 & Conant (1915) \\
\hline United Kingdom & $\begin{array}{l}\text { Good harvest and low prices led to speculation; general depression on } \\
\text { property prices affected production industries. Eighty-nine country banks } \\
\text { bankrupt; } 300-500 \text { ceased business, and there was an increased demand for } \\
\text { Bank of England's notes. }\end{array}$ & $\begin{array}{l}\text { Spring } \\
1814-1817\end{array}$ & Conant (1915) \\
\hline
\end{tabular}




\begin{tabular}{|c|c|c|c|}
\hline Country & Brief Summary & Year & Source \\
\hline United Kingdom & $\begin{array}{l}\text { Speculation in real and imaginary investments financed by unregulated } \\
\text { country banking caused a bubble in stocks and Latin American foreign } \\
\text { sovereign debt; followed by a stockmarket crash, six London banks closed } \\
\text { (including Henry Thornton’s Bank), } 60 \text { country banks closed-panic in } \\
\text { London. }\end{array}$ & April, 1825-1826 & Conant (1915) \\
\hline United Kingdom & $\begin{array}{l}\text { Three banks failed (March 1837); Bank of England gave generous advances } \\
\text { to other banks to prevent panic but still they drifted toward bankruptcy. } \\
\text { Raised discount rate and borrowed from France and Germany. }\end{array}$ & $\begin{array}{l}\text { March, } \\
1837-1839\end{array}$ & Conant (1915) \\
\hline United Kingdom & $\begin{array}{l}\text { The Irish Potato famine and railroad mania led to a steady drain on bullion; } \\
\text { reduced resources led to a panic. Firms overextended into railroad endeavors } \\
\text { and sugar plantations; firms began failing, which led to bank failures. }\end{array}$ & April, 1847-1848 & Conant (1915) \\
\hline United Kingdom & $\begin{array}{l}\text { Discovery of Australian and Californian gold fields led to massive } \\
\text { speculation and then collapse; paralyzed finances throughout world (spread } \\
\text { from the United States to Europe, South America, and Far East). Most banks } \\
\text { suspended; Bank of England the only source of discount. }\end{array}$ & August, 1857 & Conant (1915) \\
\hline United Kingdom & $\begin{array}{l}\text { Bank Act of } 1844 \text { suspended to deal with panic_-paid demands in gold. } \\
\text { Joint Stock Discount company failed and various industries discounted. }\end{array}$ & May, 1866 & Conant (1915) \\
\hline United Kingdom & $\begin{array}{l}\text { Provincial bank crisis: West of England \& South Wales District Bank failed } \\
\text { (Dec. 9) and City of Glasgow bank failure (Oct. 2) due to depressed } \\
\text { confidence. }\end{array}$ & October, 1878 & Conant (1915) \\
\hline United Kingdom & $\begin{array}{l}\text { House of Baring's portfolio was mostly in securities in Argentina and } \\
\text { Uruguay. The Buenos Aires Water Supply \& Drainage Company loan failed, } \\
\text { but the Bank of England, assisted by the Bank of France and Russia, } \\
\text { organized a rescue, which prevented Barings from failing. Short and mild } \\
\text { recession followed. }\end{array}$ & November, 1890 & $\begin{array}{l}\text { Bordo and Eichengreen } \\
\text { (1999); Conant (1915) }\end{array}$ \\
\hline United Kingdom & "Secondary" banking crisis. & $1974-1976$ & $\begin{array}{l}\text { Caprio and Klingebiel } \\
\text { (2003); Bordo et al. } \\
(2001)\end{array}$ \\
\hline United Kingdom & Johnson Matthey Bankers failure. & 1984 & $\begin{array}{l}\text { Caprio and Klingebiel } \\
(2003)\end{array}$ \\
\hline United Kingdom & Bank of Credit \& Commerce International failure. & 1991 & $\begin{array}{l}\text { Caprio and Klingebiel } \\
\text { (2003) }\end{array}$ \\
\hline United Kingdom & Barings failure. & 1995 & $\begin{array}{l}\text { Caprio and Klingebiel } \\
(2003)\end{array}$ \\
\hline United States & $\begin{array}{l}\text { State banks suspended specie payments due to War of 1812_paralyzed } \\
\text { Treasury’s operations. }\end{array}$ & August, 1814 & Conant (1915) \\
\hline United States & $\begin{array}{l}\text { Forty-six banks rendered insolvent due to demands for specie by Second } \\
\text { Bank of the United States. }\end{array}$ & $\begin{array}{l}\text { February, } \\
1817-1819 \\
\end{array}$ & Conant (1915) \\
\hline United States & $\begin{array}{l}\text { Preceded England's crisis; Bank of the United States and all other banks } \\
\text { brought to the verge of suspension. }\end{array}$ & January, 1825 & Conant (1915) \\
\hline United States & $\begin{array}{l}\text { Three banks failed (March 1837); Bank of England gave generous advances } \\
\text { to other banks to prevent panic; failures began in New Orleans and NYC and } \\
\text { spread to other cities' banks. }\end{array}$ & $\begin{array}{l}\text { March, } \\
1837-1838\end{array}$ & Conant (1915) \\
\hline United States & $\begin{array}{l}\text { Second Bank of the United States liquidated; lenders repaid but shareholders } \\
\text { lost all interest; } 26 \text { local banks failed. }\end{array}$ & March, 1841 & Conant (1915) \\
\hline United States & $\begin{array}{l}\text { Discovery of Australian and Californian gold fields led to massive } \\
\text { speculation and then collapse; paralyzed finances throughout world (spread } \\
\text { from the United States to Europe, South America, and Far East). Most banks } \\
\text { suspended; Bank of England the only source of discount. }\end{array}$ & August, 1857 & Conant (1915) \\
\hline United States & $\begin{array}{l}\text { Government suspended specie payments-lasted until 1879; drove up price } \\
\text { of gold (peaked in 1864) and all other retail items. }\end{array}$ & December, 1861 & Conant (1915) \\
\hline United States & U.S. panic due to the Civil War. & April, 1864 & Conant (1915) \\
\hline United States & $\begin{array}{l}\text { Philadelphian banking firm Jay Cooke \& Company failed, triggering a } \\
\text { recession that lasted until } 1877 .\end{array}$ & September, 1873 & Conant (1915) \\
\hline
\end{tabular}




\begin{tabular}{|c|c|c|c|}
\hline Country & Brief Summary & Year & Source \\
\hline United States & $\begin{array}{l}\text { Weak commodity prices and a series of brokerage firm failures led to bank } \\
\text { runs and suspended payments, mostly in the NY region. The output effects } \\
\text { were mild. }\end{array}$ & May, 1884 & $\begin{array}{l}\text { Bordo and Eichengreen } \\
\text { (1999), Conant (1915) }\end{array}$ \\
\hline United States & $\begin{array}{l}\text { Monetary uncertainty and stock market crash led to bank runs. Political } \\
\text { action to ameliorate the crisis; severe decline in output but the economy } \\
\text { recovered quickly. }\end{array}$ & May, 1893 & $\begin{array}{l}\text { Bordo and Eichengreen } \\
\text { (1999); Conant (1915) }\end{array}$ \\
\hline United States & $\begin{array}{l}\text { Global credit restrictions and domestic financial excesses, increasing number } \\
\text { of state banks, and a rising ratio of deposits to cash reserves set the stage for } \\
\text { a crisis. Real estate and stock speculations burst; crisis spread from NY } \\
\text { nationwide. Growth rate fell by 9\% per year. JP Morgan, the Bank of } \\
\text { Montreal, and the Treasury of NY replenished liquidity. }\end{array}$ & March, 1907 & $\begin{array}{l}\text { Bordo and Eichengreen } \\
\text { (1999); Conant (1915) }\end{array}$ \\
\hline United States & $\begin{array}{l}\text { NYSE closed until December in response to the War; however, a banking } \\
\text { crisis was avoided by flooding the country with emergency currency to } \\
\text { prevent hasty withdrawals. }\end{array}$ & July, 1914 & Bordo et al. (2001) \\
\hline United States & $\begin{array}{l}\text { Great Depression: thousands of banks closed; failures correlated with } \\
\text { particular Federal Reserve district. Bank of USA failed in December 1930; } \\
\text { between August } 1931 \text { and January 1932, } 1860 \text { banks failed. }\end{array}$ & $1929-1933$ & $\begin{array}{l}\text { Bordo et al. (2001); } \\
\text { Bernanke and James } \\
(1990)\end{array}$ \\
\hline United States & 1400 S\&L and 1300 bank failures. & $1984-1991$ & $\begin{array}{l}\text { Caprio and Klingebiel } \\
\text { (2003); Bordo et al. } \\
(2001) \text {; }\end{array}$ \\
\hline Uruguay & National Bank failed. & 1893 & Conant (1915) \\
\hline Uruguay & $\begin{array}{l}\text { Run on banks to redeem bank notes due to government decree to reduce the } \\
\text { circulation of notes. }\end{array}$ & September, 1898 & Conant (1915) \\
\hline Uruguay & $\begin{array}{l}\text { Banco Mercantil failed. A wave of bank mergers and bankruptcies } \\
\text { developed, driven by high real interest rates. }\end{array}$ & March, 1971 & $\begin{array}{l}\text { Kaminsky and Reinhart } \\
(1999)\end{array}$ \\
\hline Uruguay & $\begin{array}{l}\text { A large-scale run on banks came in the wake of the Argentine devaluation, } \\
\text { which marked the end of the Argentine tablita. Affected institutions } \\
\text { accounted for } 30 \% \text { of financial system assets; insolvent banks accounted for } \\
20 \% \text { of financial system deposits. }\end{array}$ & $\begin{array}{l}\text { March, } \\
1981-1984\end{array}$ & $\begin{array}{l}\text { Kaminsky and Reinhart } \\
\text { (1999); Caprio and } \\
\text { Klingebiel (2003); Bordo } \\
\text { et al. (2001) }\end{array}$ \\
\hline Uruguay & $\begin{array}{l}\text { The Government-owned mortgage bank was recapitalized in December } \\
\text { 2001. The banking system had 33\% of its deposits withdrawn in the first } \\
\text { seven months of 2002. In 2002, four banks were closed (33\% of total bank } \\
\text { assets), and fixed-term deposits (CDs) were restructured and their maturity } \\
\text { extended. }\end{array}$ & 2002 & $\begin{array}{l}\text { Caprio and Klingebiel } \\
\text { (2003); Jácome (2008) }\end{array}$ \\
\hline Venezuela & Notable bank failures in 1978, 1981, 1982, 1985, 1986 & $1978-1986$ & $\begin{array}{l}\text { Caprio and Klingebiel } \\
\text { (2003); Bordo et al. } \\
(2001) \text {; }\end{array}$ \\
\hline Venezuela & $\begin{array}{l}\text { Bank runs on Banco Latino, the country's second largest bank-closed in } \\
\text { January 1994. Insolvent banks accounted for 35\% of financial system } \\
\text { deposits. Authorities intervened in } 17 \text { of } 47 \text { banks that held } 50 \% \text { of deposits } \\
\text { and nationalized nine banks and closed seven more in } 1994 \text {. The government } \\
\text { intervened in five more banks in } 1995 .\end{array}$ & $\begin{array}{l}\text { October, } \\
1993-1995\end{array}$ & $\begin{array}{l}\text { Kaminsky and Reinhart } \\
\text { (1999); Caprio and } \\
\text { Klingebiel (2003); Bordo } \\
\text { et al. (2001); Jácome } \\
\text { (2008) }\end{array}$ \\
\hline Vietnam & $\begin{array}{l}\text { Two of four large state-owned commercial banks (51\% of banking system } \\
\text { loans) deemed insolvent; the remaining two experience significant solvency } \\
\text { problems. Several joint stock companies in severe financial distress. Banking } \\
\text { system nonperforming loans reached } 18 \% \text { in late } 1998 .\end{array}$ & $1997-?$ & $\begin{array}{l}\text { Caprio and Klingebiel } \\
(2003)\end{array}$ \\
\hline Yemen & $\begin{array}{l}\text { Banks suffered from extensive nonperforming loans and heavy foreign } \\
\text { currency exposure. }\end{array}$ & $1996-$ & $\begin{array}{l}\text { Caprio and Klingebiel } \\
(2003)\end{array}$ \\
\hline Zambia & Meridian Bank with 13\% of commercial bank assets became insolvent. & 1995 & $\begin{array}{l}\text { Caprio and Klingebiel } \\
(2003)\end{array}$ \\
\hline Zimbabwe & Two of five commercial banks have a high level of nonperforming loans. & 1995 & $\begin{array}{l}\text { Caprio and Klingebiel } \\
(2003) \text {; Bordo et al. } \\
(2001)\end{array}$ \\
\hline
\end{tabular}

